




THE LIFE AND TIMES OF BOOKER T. WASHINGTON 


\title{
THE LIFE AND TIMES OF BOOKER T. WASHINGTON
}

\author{
BY \\ B. F. RILEY, D.D., LL.D. \\ Author of "The White Man's Burden"
}

INTRODUCTION BY

EDGAR Y. MULLINS, D.D., LL.D.

President of Southern Baptist Theological Seminary

\section{ILLUSTRATED}

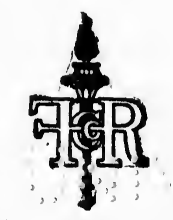

New York Chicago Toronto

Fleming H. Revell Company

LONDONANDADINURGH 


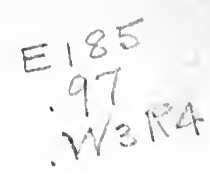

Copyright, r916, by

FLEMING $H$. REVELL COMPANY.

$\therefore \quad N$ ew. York: 158 Fifth Avenue Chìcago: $17^{\circ} \mathrm{N}$. Wäbash Ave. Toronto: 25 Richmond St., W. London: 2I Paternoster Square Edinburgh: 100 Princes Street

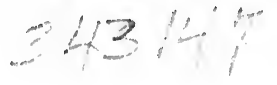




\section{TO}

All spirits of true nobleness who prize genuine worth, no matter where found or in whom 



\section{INTRODUCTION}

NE of the most complicated of all social problems during the past two generations has been that of the Negro in his social, economic, and civil relations in the South. Some writers have been pessimistic in their view as to the outcome. We have sometimes seen the view expressed in books by strong writers that there is no solution of the Negro question. This reminds one of Mark Twain's story. He carried forward the action of the characters up to a certain point, and suddenly dropped the task of writing. He informed the reader that the situation had become so complicated that he, the author of the story, was unable to handle it, and that he would have to turn it over to the reader to develop the story to the climax. This was excellent humor, and it is suggestive of the view some have held regarding the Providence of God in relation to the Negro. It is as if God had permitted a situation to develop which he himself could not handle successfully. The writer does not in any degree share the pessimistic view that the Negro question is insoluble.

The late Booker T. Washington was one of the most remarkable characters of his generation. $\mathrm{He}$ is, indeed, the outstanding Negro of modern times. $\mathrm{He}$ belonged to the last generation of slaves, and served 
the admirable purpose of showing the capacity of the Negro for progress. His career was an inspiration to every Negro with whom he came in contact. $\mathrm{He}$ was born before the war between the States, and was too young to appreciate the nature of that titanic struggle, but he grew to boyhood and young manhood during that critical period following the war known as the reconstruction period in the South.

Dr. B. F. Riley has told the story of Washington's life in the pages which follow in a remarkably interesting and effective way. He has traced the career of the great Negro from his childhood through to the end of his life. He has painted him as the ambitious, struggling, honest, earnest, faithful devotee of a great ideal for his race.

Dr. Riley has brought into prominence the characteristic features of Washington. Among these may be named the following: First, his thorough honesty. He was burdened with a sixteen dollar debt at the end of a vacation when he was attending school at Hampton. He was restless and miserable until the debt was paid. So, throughout his career he was characterized by a splendid conscientiousness.

Again, Washington was remarkably sane and balanced in his views as to the place and future of the Negro. He cherished no illusions as to social equality between the Negroes and the white people of the South. Indeed, the subject of social equality did not interest him. There were other matters of far greater moment. Washington felt that economic independence was the great need of the Negro. He was thor- 
oughly convinced that if the Negro could achieve this, his destiny would take care of itself in other matters.

Another trait in Booker Washington's character was his strong desire to unite the best sentiment among the whites and the blacks. He appealed to the best element among Southern white people and to the best element among the Negroes, and it is remarkable how well he commanded the respect of all. He was thoroughly loyal to the Negro and genuinely tactful in dealing with the white people of both North and South. $\mathrm{He}$ was at home on any platform, North or South. He was never known to fan into intensity Northern prejudice against Southern views, and he was always self-respecting in his attitude towards Southern white people. But he understood the Negro and he understood the whites, and he was unusual in his ability to mediate between the two.

Washington did much to secure for the Negro a fair hearing all over the country. He was the mouthpiece for them in their aspirations and struggles. No picture in history is more pathetic than that of the Negro in his struggles for educational and economic independence since his emancipation. Washington's heart beat in unison with all that was best in the Negro race. He built up the school at Tuskegee and did more for the economic growth and development of the Negroes than all other single agencies combined.

There has been to a certain extent a difference of opinion as to the value of Washington's work at Tuskegee, but I am fully persuaded that the final consensus of opinion among students of history will vindicate 
thoroughly the value of the work, and the wisdom of the man who led in it. Southern white people, especially those of intelligence and Christian character, are coming every day to appreciate more deeply the value of the Negro as an economic asset and the importance of giving him every advantage for his most thorough training and development.

Dr. Riley, the author of the volume before us, has rendered very fine service in the cause of Negro advancement in past years. He has devoted a great deal of unselfish labor and time to the improvement of the Negro. What he has done has been exceedingly helpful in enabling white people to understand the Negro and in encouraging the Negro to realize his own highest possibilities. Personally, I rejoice deeply that there are such men as Dr. Riley among us in the South -men who are broad-minded, unselfish and consecrated to the highest ends of the race, whether the race be black, yellow, or white. The Biography of Booker $\mathrm{T}$. Washington which he has written will, I believe, take a very important place in the literature of the Negro. I rejoice in its publication, and believe it will be found to be a contribution of incalculable value to the life, development, and prosperity of the Negro and to the enlightenment of all friends of the Negro race.

E. Y. Mullins.

The Southern Baptist Theological Seminary, Louisville, Ky. 


\section{PREFACE}

$7 \mathrm{HE}$ position held by Booker T. Washington in the biographical annals of America is a unique one. Others before him had risen from obscurity to eminence, and others had mastered serious difficulties in their upward climb, but in addition to all these the subject of this volume was hampered by the fact that he was born a Negro slave.

An additional disadvantage was that of the peculiarity of the period in which Washington rose from deep obscurity to high eminence. The temper of the times was such as to be severely against him. Race aversion was at its height, and the prevailing estimate of the Negro was the lowest. From no possible source could encouragement be expected. Hence the possibility of recognition had to be created by the exslave himself. By dint of rare genius he had to generate a new atmosphere, a condition that seemed impossible, in order to the recognition of his peculiar gifts and qualities.

In this respect certainly Booker $\mathrm{T}$. Washington is unique among the great of American history. To have done no more than to offset the difficulties springing from lowliness of life and extreme penury would have ranked him alongside many others whose names adorn our biographical history. But when added to these were the stigma of slavery and the adverse conditions of the times, the lot of the great Negro was just so 
much the severer and his task of achievement the harder. To this extent does he distance pthers with the earliest years of whose lives are associated lowly cabins, menial struggles, and the pinch of privation.

How this was done is sought to be shown in the chapters of this volume. Though of another race, the present biographer is not affected by the consciousness of the fact that he is writing of a Negro, but of a man. Nor is it sought in these pages to diminish a full statement of the fierceness of the times through which the subject of this volume had to make his way to the attainment of the preeminence which he reached. Absolute frankness and fairness have been observed throughout.

The greatness of the Negro educator and reformer is as conspicuously shown in his novel mastery of the difficulties of the period as in the rare qualities of his character. That an ex-slave should have even measurably succeeded with the odds so overwhelmingly against him would have been creditable, but when he scaled the slippery heights with merit so unquestioned and conspicuous as to subdue opposition and compel general recognition, he is worthy of rare distinction.

In the preparation of the present volume there has been no disposition to minimize defect in order to exaggerate unduly the worth of Booker $T$. Washington, but throughout the effort has been for faithful fidelity to fact. As facts have been ascertained they have been presented without modification or extenuation. 


\section{CONTENTS}

I Antecedent Conditions • • • I 15

II Nativity and Early Life . . . . 28

III A Common LAborer . . . . $\quad .38$

IV Hampton Institute . . . . 5 I

V. The Genius of Hampton Institute 63

VI Ventures into the World . . 77

VII In the Vestibule of His Life Work 9I

VIII TUSKegeE . . . . . . . . 106

IX Supreme Diffiçulties · • . $\quad$ - 123

$\mathrm{X}$ Cultivation of Cordial Relations $\mathrm{I} 38$

XI The Interest Deepens . $. \quad . \quad \mathbf{r}^{2}$

XII Still Achieving, Still Pursuing . 166

XiII The Prospect Widens . . . 177

XIV National Prominence . . . 186

XV Effects of the AdDress . . . 202.

XVI HONOR FOLlOWS WORTH . . . 215

XVII Widening Influence and IncreasING Power . . . . . 23 I

XVIII Race Organization and ConstrucTION . . . . . . . . $24 \mathrm{I}$

XiX The Spirit of Enlistment • • 255

XX To Europe . . . . . . . . 268

XXI LAST Years . . . . . . . $\quad$. $28 \mathrm{I}$ 



\section{ANTECEDENT CONDITIONS}

TEADERSHIP is indispensable to the guidance and the development of every people. Even in the rudest states of society the necessity of leadership is instinctively recognized, and because of the possession of certain qualities, chiefs are chosen to lead and command. In the juncture of certain crises, leaders have sometimes suddenly arisen as the direct creation of an emergency; hailing even from unconjectured quarters, yet having just the qualities needed for the exigency. In the absence of a leader among the ancient people of Greece, Homer created Achilles, and by the display of his mythical exploits fired the hearts of a barbarian race which finally won the station of leadership in the world's thought.

When an eminent leader appears among men there is at once activity in tracing his lineage to its source in search of the discovery of the germ that first gave it life. If the blood which courses through the veins of a hero bears upon its own tide the virtues by which he is distinguished such an one becomes preëminently unique.

In the dawn of the emancipation of the slaves of the South, no people ever stood in direr need of leadership of a peculiar type. Their situation was an ex- 


\section{6 LIFE OF BOOKER T. WASHINGTON}

ceptional one. An exotic race, long enslaved, and providentially left amid its former circumstances under conditions peculiarly pitiable, the demand was most urgent. Original paganism in the fatherland of the black race, followed by centuries of bondage in a civilized land, left these black people in an anomalous condition. Inspiring leadership was needed not alone to sound the rousing note of beginning to achieve for themselves, but to stand at the front of the file and direct to an outlook of race usefulness and aspiration.

At the gateway of freedom the race was in confusion. Their ancestors, wrenched by compulsion from their native shores, had been brought half the circumference of the globe, there to be placed in conditions of enlightenment and progress for the white race; their descendants had toiled as slaves. Touched by the fresh vitality of a climate more favorable to the generation of energy, and quickened even in their torpid minds by their surroundings, thought began to germinate like seeds long buried, and a once inert race gradually awoke to mental activity even under the sway of protracted servitude.

Conditions of dependableness could not have been more pronounced than in the case of the imported and enslaved man from Africa. His will was utterly subordinated to that of another, and had its obliteration been possible it would have been done. Kept in enforced ignorance as a means of increased usefulness to the owner, and yet provided with the necessary amount of training to make him a valuable laborer, it is not a matter of surprise that when the shackles of the slave 
were broken asunder, the Negro was somewhat ready, because of such training, to enter on a new sphere of life, even if in a crude and bungling fashion. He had been considered by his once superior owner only as a machine. Failing, often, to grasp the change wrought by the new situation, the dominant ex-master still thought that the freed slave, when unsupported by stronger props, would relapse into original paganism, or else, in his dependence, would be forced back into practical servitude.

In a torrid zone and in haunts of inertia where energy was paralyzed and where physical effort was unnecessary by reason of the prodigality of nature, this estimate might have been justified. But two powerful forces had mightily told on a race now more American than African, one of which was a favorable climatic change, and the other the stimulus afforded by the spectacle of an advanced civilization.

Both in energy and in character these black people had been largely transformed from the lowest barbarism to at least some realization of civilized ways. To assume that with the relaxation of force and of oversight they would involuntarily turn backward, was to assume that which had never been true of any people under similar conditions. Unconsciously to himself and unobserved by his master, the Negro slave had been ripening for the freedom which must inevitably be his. This was foreseen by Jefferson, who wrote in his diary just after the Revolution, “ Nothing was ever more inevitably written into the book of fate than that these people will be free." 
The planting of the Negro on the salubrious and enlivening shores of the New World was not unlike that of sowing rare and exotic seeds from a distant quarter of the globe. Time was necessary for adaptation, germination, and for adjustment to new conditions, but when they should spring into new life there would be profitable rootage and fruitage. The profit to be derived from the enslaved African was dependent on a certain degree of development in orde to reach desired results, but during this process, while the slave was contributing to the wealth of his owner, he was, at the same time, slowly rising in the scale of civilization. This needed only the favor of opportunity in order to the development of forces long hidden and obscured.

With the Negro the same laws were operative as with any other element of humanity, and when the conditions attendant on slavery are taken into account, it is not so much a matter of surprise, after all, that the black man swept rapidly forward in achievement. The discipline and direction of his life in slavery, while he was within full view of advanced civilized life, was his course taken in the school of civilization. It would have been more surprising had the emancipated slave not moved rapidly forward.

Almost throughout the reign of slavery indications were afforded of the longing of the Negro for enlightenment. The readiness of the more favored slaves to acquire the rudiments of learning and the proficiency to which many were brought in the different trades of handicraft showed their responsiveness to 
the advantages of civilized life. An idea long prevalent in the states of the South was that enforced ignorance made, the Negro more content with his lot, and therefore a more serviceable man, while if he were taught to know his real condition it would result in mischief alike to himself and to his master. It was from this condition that there grew the assertion of the gross mental inferiority of the Negro. That which the Neq? has shown himself capable of becoming within the first fifty years of his freedom, is a direct refutation of this theory.

Naturally enough the Negro has developed many excellent qualities since his emancipation, of the existence of which there was afforded no evidence during the prevalence of slavery; but this is evidently due to the fact that for practically the first time a favorable opportunity has been afforded. The adverse judgment pronounced against the Negro in the dawn of his freedom, and the predictions concerning his destiny, were founded on fallacious premises and suggested by precedents that were strained. It was quite common to refer to that which the Negro had failed to do in regions like Haiti, San Domingo, and Liberia, and rarely to that which he had accomplished in Cuba), which was nearer the temperate zone. In the regions first mentioned the Negro had fallen short, but there he was still within the compass of a retarding climate. In Cuba he owns plantations and banks, and lives in mansions. In the American states, climate stimulates energy, both physical and mental. During the first years of the freedom of the Negro, the task imposed 
on him by previous conditions of servitude was a double one- he had both to undo and to do. He had to disencumber himself of the consequence of the false notions of his master in whose general estimation the slave was little more than a brute. The treatment of the masters was in keeping with this estimate. Deprived of advantages of enlightenment and with no hope of ever gaining it, the slaves naturally fell into a state of apathy. They came to think of themselves as little better than brutes, and their lives were generally squared to that estimate. This was pointed out by the masters as an evidence of intellectual inferiority, and was further interpreted to mean an abject condition which Providence designed for the Negro. From all this the freed slave had to extricate himself, while still pushing ahead toward the attainment of a higher plane of life.

Scarcely could the condition of any people have been more abnormal than that of the slaves of the South at the outset of freedom. For generations they had longed and prayed for liberty. The strivings within them had often found vent in prayer in their squalid quarters on the plantation. They pined for that which, when it came, was an embarrassing boon. It was at first-liberty without ability of direction. It was a confusion of joy with no foretaste as yet of its grim reality of meaning. The sense of independence was there without any idea of self-dependence. It was a jumbled mass of glee, crudeness, capability, possibility, hopefulness without foresight, and of kindly disposition in poverty. What was to become of a mass like 
this? What destiny awaited this incongruous host? The future must tell.

It will require considerable time yet for the Negro to get rid of much that is ancestral to the race-the inheritance of centuries. Not only must he be patient, but so must all others. Prejudice, aversion, force, violence, and depreciation, will not tend to lift the Negro up, but to cast him down. To demand a display of quality equal to that of those favored by centuries of advantage is both unreasonable and absurd. The Negro race is yet in its childhood. While the criminal class deserves punishment for crimes committed, reason should recognize the past disadvantage of the Negro, and not exercise vengeance which is contrary to the proper execution of the law. To this the Negro in his present condition is much exposed. The rule of vengeance rather than that of reason, is debasing alike to the race on which it is wreaked and to the inflictors, and, in the end, to American civilization.

Time is needed for the Negro to pass from the effects of the stigma of slavery, from under much unreasonable race prejudice and preconceived theories which, while largely insubstantial, operate with all the force of fact. But the advancing black man is certain to commend himself as he shall advance. To withhold credit from the meritorious, no matter where found, argues something wrong with him who entertains such views.

In his present condition, the Negro needs friends, and friends of superior advantage and circumstance. 
$\mathrm{He}$ is in the South to remain as an integral part of the country. To aid in his improvement is the clear duty of advanced citizenship. To make him worse, no matter by what method, is to retard general development. To demand conformity to an order of society equal to that of the higher and more favored class is as unreasonable as to expect children to be men. Where he shows signs of improvement he should be cheered by inspiration, and brought to a state of citizenship as rapidly as possible. Where by unusual force of energy and wisdom he succeeds, he should be accorded respect and encouragement. A course like this is consistent with patriotism, philanthropy, morality, and Christianity.

The astonishment often expressed at the remarkable strides made by the superior class of Negroes is not reasonable. They are simply responding to conditions which favor development. The results are but an exemplification of the law of the adjustment of means to ends. In a certain zone in the state of Washington, it has been found that horses can be brought to the highest degree of development; in a certain region of California the finest specimens of domestic fowls can be produced, while in still another the best celery of the world is grown. Given the proper conditions, and the requisite capability of responsiveness, and we have the logical results. Not otherwise is it with men.

It is not difficult to apply these principles to the Negro race as it was and is. Nothing is clearer than that neither the paganism of ages with all its attendant debasement, nor the oppression of slavery, could ex- 
terminate capability and responsiveness in the race. Under right conditions these germs were stirred into new life. The things which seemed to be hindrances to the black man in his enforced servitude turned out to be helps.

Nor does this justify the institution of slavery. On the one side was the evil imposed by the mastery of the white race, while on the other was the unintentional good done the Negro. He underwent much of cruelty and of imposition, but it was not without much ultimate profit to himself. While not justifying slavery, this vindicates the ways of Providence.

Fresh from servitude, and equally fresh in the flush of a new-born freedom, the Negro stood at the gateway of a mighty transition. The way before him was yet untried. In the great mass he was dismally ignorant; his qualities of coarse vice had been unchecked in slavery, his moral perceptions were blunted, battered, while the exercise of independent action and will was much like the feet of a baby before he takes the first step; his senses of discrimination and of judgment were sorely restricted, and his powers were yet undrilled in the school of self-reliance.

This was true of the colored man as an individual, but what about his environments? He was a victim of poverty. Nothing was his in the midst of the wealth of his own creation. He was penniless, homeless, foodless, landless. He was the innocent victim of surroundings that seemed to mock him. Two possessions were his, however, and two alone, and on them he was absolutely dependent. These were his 
muscles of iron and a large stock of hopefulness. With the one he could labor, by the other he was cheered. Whatever the position of the Negro, his spirits never forsook him. If sad, his sadness was softened by song. No gloom was suffered to abide on his spirit even while laboring under the lash. As he cleared the forests, the echoes of his ax were accompanied by gusts of glee; as he turned the furrows, there was the freedom of song; as he reaped the harvests of the master there was melody in his labor. Often even after the exacting toils of the day were over, he would seek vent for his pent-up spirits in dancing with tired but agile feet in response to the fiddle and the discordant notes of the old banjo. Subjected to the castigation of the lash, he cherished no malice, fostered no deeply-nourished grudge, harbored no revenge, but bearing from the punishment the marks and scars of affliction, he was yet cheerful, docile, kind, and loyal as before. Adversity could not eclipse his cheerfulness, nor oppression dampen his joy.

The Negro is chided and criticised for this cheerfulness which is often interpreted to mean indifference, yet it is to him a natural reserve fund, an asset of character necessary to his condition, an invisible rod and staff that supports him when all else is gone. With muscle and hope the Negro faced the future undismayed by the jibes of his superiors in life-conditions, and undaunted by the discouragements which frowned in the path before him.

Along with his freedom came aspiration, a new possession which would have been useless in slavery. 


\section{ANTECEDENT CONDITIONS}

Its birth in his being gave fresh elasticity to hope, and this sought expression in education. To his bewildered mind it had been a profound mystery how his master by looking on an open paper or book could derive so much pleasure. In the early days of his freedom the black man set himself to solve this mystery. Among the ex-slaves, with few exceptions, the idea of education was, in the beginning, as insubstantial as the air, but they knew enough to understand that it could be had by the mastery of books and thus, with hungering and thirsting of spirit, they fell to study. There was no limit to the ridicule to which the ignorant searcher after knowledge was exposed, nevertheless he plodded on his laborious way. His soul was on fire for enlightenment, and in this fact lay the chief hope of a groping race.

Within a few years potent signs began to appear. From obscure and unexpected quarters came former slave boys and girls, incipient leaders of the race. The law of sacrifice to which the Negro had paid abundant tribute now began to assume expression in the appearance of men and women of worth. The former slave began to be heard and felt. Hence came the erratic, but none the less unquestioned, genius, John Jasper, of Richmond, Virginia; the oratorical C. T. Walker, of Augusta, Georgia; the gifted statesman, B. K. Bruce, of Mississippi; the wizard of finance, Richard H. Boyd, of Nashville, Tennessee; the pioneer banker, W. R. Pettiford, of Birmingham, Alabama, and, last of all to be named in this connection, the monumental race-builder and civilizer, 
Booker T. Washington. Hence, too, has come an army of worthies in the wake of these, who have gone into all the departments of human activity with astonishing success.

Necessarily, at first, Negro leaders were exceptional. They stood far apart and few, along the heights, beckoning the race upward. They were the forerunners of Negro success, the dispellers of doubt of Negro capability, the indicators of that soon to be. The generation next succeeding that of the slaves witnessed the uprising of an army of Negro worthies whose achievements astonished the world. Now, it is rare to find a Negro who cannot read and write. With steps timid and faltering, the Negro first entered on the professions, trades, and vocations, but now all of these have their worthy colored representatives.

Original theories of the intellectual inferiority of the Negro were overset within a few years, and on the part of many the original estimate of the race was reluctantly surrendered. Negro successes were regarded at first as sporadic, but objections were hushed when Negro education became general. Fact had convinced.

This is but a rough and imperfect review of the first struggles of the race, a background of the history of a people, now still achieving, still pursuing, as they face the years of the future. The survey prepares us to take up the career and labors of one into whose short life of wonderful activity were crowded momentous events, and on whose integrity the destiny of a people of millions living and beginning under the 


\section{ANTECEDENT CONDITIONS}

conditions already described, depended more than on any other. The changes that have been rapidly wrought within the last half-century have made it possible for a descendant of slaveholders cheerfully to assume the task of committing to permanent form the extraordinary life of a slave boy-a life which, through a period of four decades, was such as to elicit not only the attention and interest of the world, but its highest commendation. In the chapters which follow will be recorded the life and times of Booker Taliaferro Washington, the famous Negro educator, reformer, elevator, pacifist, and leader. 
T $\mathrm{N}$ tracing the life of Booker $\mathrm{T}$. Washington, it is not to be presumed that the pen of a white biographer will be restrained to any extent from the fullest expression because the subject was a Negro. While there is no disposition either unduly to exalt his worth or to exaggerate the importance of his work, there will be accorded to him the merits of his just deserts. The simple fact that he was a distinguished American who wrought mightily in his generation for the good of both races, entitles him to full recognition and to the perpetuation of a fame worthily won.

Of not a few great Americans the conditions of birth have been low and obscure. The birth-place of at least one brilliant military commander is unknown, so humble were the conditions of his family and so great is the lack of data concerning his advent into the world. The most eager and diligent search of biographers has been a failure on this point, yet he rose to the command of the American army and became a chief magistrate of the nation. The birth of another president is wrapped in obscurity; during almost thirty years of the first part of his life he was an humble laborer, a rail-splitter, and was inured to penury and 
the deepest privation. Still another president was not able to read till after his marriage. The early difficulties of other eminent Americans might be named, but these are sufficient for the purpose now in hand.

Certainly none who attained to distinction could have been more obscure than Booker T. Washington, and his early life was handicapped by the additional fact that he was a Negro slave. Still another fact which operated most seriously against him was that his career was begun when race antagonism in the South was the severest. That one in his position and condition should have been able to attain to a station of any consequence is most remarkable, and that he should be able to master the most obstinate obstructions, and to achieve the seemingly impossible, crowns him with a degree of merit to which the others named cannot possibly lay claim. He was of a despised race; he was ignorant and poor; the tension of the times was such that under ordinary conditions any expressed ambition on his part to accomplish that which he succeeded in achieving would have invited violent opposition; and, in addition, he was without friends to advise and direct.

Born in a slave hut, on an interior plantation, near a cross-roads post office called Hale's Ford, in Franklin county, Virginia, about the year 1857 , is the earliest record of this notable man. On some of the plantations of the South the birth of each black child, the deaths of slaves, the purchase and sale, and whatever was of consequence went on record, but on the plantation on which Washington was born no such 
care was taken. Slaves knew nothing of dates, and events were remembered by association with certain other events of note. By such association Washington's mother was enabled to indicate the approximate year of his birth.

The slave child was called Booker, by which name he was known till he was quite a lad. His mother, Jane, was a cook for the slaves on the plantation. Like other slaves, she was known by that name alone, but when asked for her full name, she would give that of Jane Ferguson. Nothing is known of Booker's master other than that his name was Burroughs.

The time of the birth of this young slave, Booker, was that of a struggle, the premonitions of which were already beginning to appear. In I857 James Buchanan took his seat as president, the last representative of his party to do so for thirty-eight years. The events of the time gave a fresh impulse to the inevitable conflict. The assumed sincerity of $\mathrm{Mr}$. Buchanan in his initial statement to Congress that slavery was a dead issue, had the direct effect of reviving it as an issue, and his administration was signalized by preparation for the great, Civil War. In the same connection may be named another event which occurred shortly after the inauguration of President Buchanan, that of the opinion rendered by Chief Justice Taney in the case of Dred Scott. These deliverances seemed to sentence the slaves to perpetual servitude. That there was born at the time of these occurrences in the highest national councils at Washington, a little slave, on whom would be providentially 
imposed the supreme task of leadership in undoing the complications into which the country was at that time steadily moving, is a remarkable coincidence. Nothing could have seemed more remote than such a possibility.

While the events of the time moved in ominous procession toward a long and bloody conflict of sections, the ignorant young slave on the plantation in Virginia was subjected to all the conditions incident to such on the plantations of the South. There was nothing to differentiate him from any other youthful slave. Not the slightest indication was given in anything said or done by him of that which he was destined to become. His hard life in the midst of slavish environment was a mere matter of course. Yet from this abject quarter he was to come as a harbinger of a new era.

"Manners with fortunes, humors turn with climes, Tenets with books, and principles with times."

No less improbable seemed the emancipation of his race, yet within the next half dozen years a proclamation of emancipation would be issued, and thus would be enacted the first scene in the drama of his eventful life. Even as late as I86I, the vice-president of the Confederacy, in his famous "corner-stone" speech at Savannah, Georgia, said that "slavery was the natural and normal condition of the Negro because of his racial inferiority."

The years immediately following that of Booker $\mathrm{T}$. Washington's birth were those of turbulence. Mr. 


\section{LIFE OF BOOKER T. WASHINGTON}

Buchanan had manifestly misconceived the spirit of the times. A storm of abolition violence broke forth afresh in the North, while the contests on the floors of Congress waxed fiercer. Books in denunciation of slavery and others written in its defense, poured in a torrent from the press, and journals on both sides of Mason and Dixon's line warred with fury. Poets, teachers, professors, ministers of the gospel, editors, authors, speakers on the stump and on the platform, hastened the "irrepressible conflict." Slavery was the dominant topic around the fireside, in the village group, in the circles of hotels, and in the corridors and chambers of the national Capitol. The atmosphere was more pregnantly charged with hostility as the administration of Mr. Buchanan drew toward its close.

Meanwhile, the little slave who was destined to play so conspicuous a part in the subsequent drama, was being nursed on the lap of his slave mother on an obscure plantation in Virginia. Events in our national history were never more capricious and phenomenal than in the years stretching from 1857 to 1882 , It was an iconoclastic period. Passion raged to the subversion of judgment, and policy was often exercised in defiance of principle. Views were changed by passing events rather than by the consequences toward which they evidently tended. The coolness or deliberation of men was incapable of lofty thought and of cautious action. Terms and designations once cherished, became those of opprobrium. Excitement and not reason ruled the hour. Anglo-Saxon fervor was 
wrought to the highest degree. The reaction was destined to bring some marvelous changes.

The period of mind clashing against mind was followed by that of contending armies in battle. Virginia was the chief theater of the long struggle, but the scenes of carnage were quite apart from the region in which the young slave, Booker, had passed out of the swaddlings of babyhood to the activity of boyhood with no other prospect than of being a toiling slave as his ancestors before him had been.

When the armies of the Confederacy had capitulated and the war was over, a new era came; the slave was forever free, the great Emancipator had been assassinated, new complications had arisen, the passion of contention was still rife, the victors were pressing their issue to contemplated consummation, the defeated were still resisting as far as they might, and there came a strain to the utmost tension between the former master and the erstwhile slave.

It was a time of political agitation, and political parties were each playing for the utmost advantage possible, the one riding at high tide, the other resisting to the utmost. On the ex-slave fell the consequence of it all. Without any positive or direct agency in the events which so vitally affected him, he was the burden-bearer of the results of the continued contention. That which had been true for many years concerning the black man was still true.

The years immediately succeeding the close of the Civil War were chaotic. With reference to the late slave population they were peculiarly so. Without 


\section{LIFE OF BOOKER T. WASHINGTON}

initiative because long dependent on others, ignorant, penniless, homeless, and foodless, - scarcely could the condition of any class have been worse. In bewilderment these unfortunate people were scattered, many hanging about the camps of the conquerors, others wandering idly here and there, multitudes swarming the cities, while not a few threaded the highways of the country hungry and in search of employment elsewhere than on the plantations of their late servitude, the impression being that to labor on these would imply anything other than freedom. It was a period of dark transition to the Negro.

Nor was it less so to the whites. The old system was broken up. Extensive plantations, once yielding immensely, were now lying idle. Land was a burden to the former slaveholder. Gloom had come where before there had been contentment and ease. It was a period of irritation resulting from the dire effects of war. Business in the South was stagnant, and the price of goods high. The races now standing apart regarded each other with distrustfulness.

When the armies of the Confederacy surrendered Booker T. Washington was a mere boy. $\mathrm{He}$ heard the terrors of the situation discussed by his elders. $\mathrm{He}$ recalled in after years the impression made at a period when children become receptive of the things occurring about them. He heard of the surrender of armies, and of freedom, without understanding its meaning, and shared in the shifting movements of his perplexed people. As before stated, simultaneously with the comparative settlement of conditions, came 
the desire of the freed people for education-the first real aspiration of the emancipated Negro. The first schools for them were thronged alike by the aged and the young thirsting for enlightenment. Not infrequently in the same crowded schoolroom were gathered, grotesquely and yet pathetically enough, the spectacled grandfathers and grandmothers, and the small children, all burrowing into the mysteries of the blue-backed speller. The delight afforded by the acquisition of the alphabet, and the ability to spell syllables of two letters, was an incitement to bore with increasing labor and zeal into the profounder mysteries of orthography. In these excitants the clumsy boy joined with the other children, and, indeed, with those of every age, with a genuine ambition occasioned by the excitability of the situation.

It was some years later that the vision of achievement began to loom for him on the horizon of the future. He was impressed by the unusual struggles of his people to gather knowledge as well as by the disadvantages which encumbered them. The ex-slaves were very poor, and the few schools provided for them were, for the most part, very indifferent. A few Northern teachers had come South to aid the freedmen in their educational struggles. But they were socially ostracized and otherwise embarrassed.

Then came the era of reconstruction. The most designing of low politicians from the North uniting with a similar class from the South, entered on the work of deception, by pretense of kindness to the poor, deluded colored man; but they brought to his already 
weary shoulders a new burden, involving him in fresh trouble. And when they had to flee, they left the Negro in his helplessness, with the results to shoulder. Demoralization waxed into hostility, and then into violence.

The years of the boyhood and the young manhood of this sketch were those of deepening depression to his people. Throughout the states of the South the situation grew worse as time went on. They were the years of the first venture of the Negro into the sphere of independence-those of the first steps in experimental citizenship. This was offset by a corresponding growth of irritation in the whites. Intent to demonstrate in some way his sense of liberty, the Negro would not readily comply with the wishes of the whites, and this would arouse increasing sensitiveness, as the now assertive black man had just previously, as a slave, been plastic and docile. The whites could not yet understand why a Negro should not obey when ordered, and when he declined, it was taken as an expression of impudence, and friction would ensue.

The first efforts of Negroes in the spheres of independent action, especially in that of industry, were generally derided because of their awkwardness and blundering, though in some instances the friendlier and more sympathetic of the whites would aid them in their local endeavors, especially in the formation of their religious organizations.

The Negro leader of the time was a politician, which made him especially obnoxious to the whites, while the colored ministry of the period was generally illiterate 
and obscure, and therefore without influence. For a long time the only point of contact between the races was that of employer and employee. To add to the irritation of the time, detachments of federal troops were stationed about the country, vested with authority, to whose commanders reports would be made by the Negroes, and occasionally white men would be placed in prison in consequence. Greater fierceness was aroused when Negro constabulary squads were sent out to arrest the whites. These conditions prevailed for a period of fifteen years before Booker Washington appeared on the scene. 


\section{III}

\section{A COMMON LABORER}

7 HE sudden burst of freedom for the slaves of the South, an event ushered in practically after the surrender of the Confederate armies, was the occasion of boundless joy. The proclamation of freedom by Mr. Lincoln in 1863 , two years before, was a merely formal deliverance at which the slave owners at the time only hooted, so sanguine were they of final success. Slavery was destined to await the final surrender of the forces of the South.

To an ignorant people the full significance of the gift was not at first understood and appreciated. The general idea of the boon was the crudest. As slavery to the slave meant labor, so to him freedom meant a reversal of condition-it meant immunity from toilit meant rest. Beyond that conception as a final idea, the ordinary slave thought did not go. Consequently, with slight exception, the Negro was not disposed, when freed, to labor on the same plantation from which he had come, nor for his former owner. Neither was he disposed to adopt the name of the master; when he came to assume a surname, he generally took that of another, sometimes arbitrarily, sometimes from some former owner of his ancestors.

Among the earliest ambitions of the late slave was 
that of a middle letter or name. If his given name was "Thomas," he would attach to it some other of his own choice, brothers and sisters of the same family bearing a variety of assumed names. Again, the middle initial might signify a name or it might be merely what they called their "entitles." On the plantation as slaves they were known by their given names only. To the recent slaves this assumption of a name was one of the necessary accompaniments of freedom. Their ambition was to have their names sound like " de white folks"."

With the passing of the first passion of joy of the liberated slave, came the stern, cold pinch and pressure of necessity. Labor was still as exactingly demanded as before, but it must now be done on a basis entirely different from that of slave regulation. Every one must now become his own regulator, both with respect to the character of the work to be done and the wages paid. Here the ignorant black was at a great disadvantage. He knew nothing of the value of wages and less of the value of money. Rates for labor were low, prices for goods high, and the possession of a few dollars was a peculiar delight. In his ignorance he was exposed to every sort of extortion and disadvantage, of which not a few of the whites availed themselves, although, on the other hand, many dealt with the strictest honesty.

Another serious handicap to the blacks was that of the dramshops. It was a period when disreputable saloons held sway. One was at every crossroads, while in every village there were a number. Denied intoxi- 
cants in slavery, the Negro now exulted in the privilege of drink. The barroom flourished at the expense of his victimized ignorance. This induced crime and, in turn, violence. The irritation prevailing, the ignorance of the blacks, and the abundance of liquor, produced a situation the most appalling. Amidst these early conditions moved the future leader of his people. A mere boy yet, scarcely beyond the period of childhood, he was already anxious to improve his condition. In quest of the best position possible, his stepfather had gone to the salt mines in the Kanawha Valley of West Virginia, whence, later, he summoned the family to follow.

At this time Booker had scarcely turned into the teens. He helped dump the meager household goods into a cart to start overland to West Virginia several hundred miles away. Wide and deep streams were to be crossed, besides mountain ranges. He must walk for the most part, as the roads were rough and the team of oxen was small. This was Booker's first venture into the world. Till now he had scarcely been beyond the horizon of his plantation home. Barefooted and bareheaded he trudged slowly along the way following the wagon. Sharing in the eagerness of others of his race for educational enlightenment, he had not yet learned the first letter of the alphabet.

A long, tedious journey of weeks brought the poverty-stricken family to Malden, West Virginia, the center of the salt and coal mining region. Bad as the domestic conditions had been on the plantation, they were here even worse. A temporary shanty 
standing among many others, the abodes of the miners, with only the scantiest comfort, and with abounding filth, bad water, coarse food, a reeking atmosphere, vice shocking and open, and plenty of hard laborthese made up the elements of the new surroundings. $X$ Here Washington was to live and labor for years as a common workman. He was duly assigned to work at the salt furnaces along with a mass of laboring men, rising sometimes at four in the morning to begin the labor of the day. It was here that he learned the first characters in the rudiments of knowledge. Each saltpacker had his barrels numbered, that of the stepfather of Booker was i8. Without knowing the meaning of the figure, he learned to recognize it wherever he met it, and know that it meant eighteen.

Booker was not indisposed to labor, he did it uncomplainingly, but within him the fire burned for knowledge. To his ignorant but sympathetic mother he made known the intensity of his desire, but her consolation was slight, as she could only say to him that maybe someday it would be better, and he could learn to read. He had seen other boys with spelling books, and he craved to own one too. By some means his poor mother was enabled to buy him one. This was a joy unspeakable. He longed to master it, but how? Not a person in all the laboring community knew a letter of the alphabet. He must seek himself to unravel the mysteries of this, the first book he had ever held in his hands. At odd moments during the intervals of labor he was hard at work on his mysterious speller, seeking to evoke its hidden meaning. 
There were white overseers about the camp, who doubtless would have been glad to help an aspiring lad over his alphabetical difficulty, but he knew but little of the whites, and was shy of them. He knew enough to know that a mastery of the alphabet was essential to the acquisition of the rest, and by some means he hammered it out for himself, and could combine the letters into short syllables, but the pronunciation of these he had to wait a future opportunity to learn.

Conditions slightly more favorable came a little later. A colored youth who found his way to Malden from Ohio, having had some advantages in the public schools of that state was able to read with ease. Among the miners and salt-packers, this young man was regarded a prodigy because he could actually read, like a white man. At the close of each day he was surrounded by a group of eager listeners to hear him read the newspapers. Booker watched him closely, studied him with eager care, and many a time left his presence, longing to be able to read as did he and resolved to learn. He was willing to stop when he could do that, as he then thought. This became to him a fresh incentive to his already intense desire to have an education.

The advent of this partly-educated youth had a stimulating effect on the community, and soon there was a general desire for a school for the colored children. This proved an entering wedge to a change in the mental and moral uplift of that really depraved community. But where was a teacher to be had? Some suggested the engagement of the Ohio youth, 


\section{A COMMON LABORER}

but he was too young to govern a school, and that suggestion was dismissed.

Meanwhile, another colored man from Ohio came on the scene. He was an ex-soldier from the federal army, and in addition to his ability to teach, he had the advantage of maturity. He was employed on a slender salary, each patron paying by monthly installment for the services of the teacher. For two reasons it was deemed wise that he should "board around "that is, by turns, spend one night with each of the patrons. It was thought that it would arouse the people from their lethargy of degraded existence, to have a person of advanced culture in their homes, and that thereby he would be the better able to afford aid to the pupils in their studies. The list of homes was duly made out for the teacher's visitation, the school was opened, and the round of visits begun. "Teacher's day" became an event in each home in the community. There was every preparation to make his visit a pleasant one. For once, the squalid surroundings were cleared up, the house was put in as perfect order as possible, and all the domestic arrangements underwent a reformation. The result was a gradual change in the squalid community. People found that conditions could be improved, they liked it better than the original circumstances, and the place gradually began to change, and the people to improve in every way. These little things were a turning point in that community, which now started upgrade.

Similar changes were beginning to take place elsewhere among the colored people of the South. As 
yet, no provisions had been made in the South for a public school system. In truth, the country was a scene of general desolation. Blackened chimneys stood sentinel over the ruins of many towns and cities. In many instances, farms were still as they had been left by the tramping armies. The struggle on the part of all alike was for a livelihood. The one-armed soldier was at work in the fields, and the once wealthy land barons were concerned about making ends meet. A great industrial system had suddenly collapsed into a common crash of ruin, and the people were in perplexity. Besides all this, an ex-slave population of millions was adrift, restless, ignorant, aimless, homeless, and leaderless. Conditions were chaotic.

On its own initiation, the freed race began to found schools-to found them in their ignorance. It was a racial groundswell. About five per cent of the emancipated people could read and write, and these were not slow to inject the spirit into the rest of their people, and by the time that the states were ready to inaugurate a system of schools, no class was more responsive than the late slaves. Some of the former slaves who had heard of colleges and universities, but had never seen either, aspired to found such for their people. The most remarkable instance occurred at Louisville, Kentucky, where a group of unlettered exslaves met in an old building in August (succeeding the close of the war, in April, 1865) and, though bearing the marks of slavery on their bodies, and simply knowing that a university meant a place of learning, took steps to begin a school which gradually 
developed into what came to be known as the State University of Kentucky, a large and flourishing college for colored people which stands today in Louisville, with buildings and grounds in the heart of that city. Throughout the years, from that early time till now, it has done excellent work, not alone for the colored race but for the commonwealth of Kentucky, and is still a great educational lighthouse to a struggling people.

To this work of the race throughout the South, these people were actuated, not because any possessed prosperity, for they were extremely poor, nor by any prospective wealth, but purely in recognition of the necessity of education for their people if they were to be able to cope with their peculiar difficulties, and rise in the scale of civilization. The money contributed to this end, no matter by whom, was never more worthily given. To study this movement, at a time so inauspicious, and with an outlook so unpromising, is to see that the southern Negro, made over anew from his ancestral savagery of two or three centuries before, is not a comedy race. In these beginnings was the germination of a people whose coming worth and importance would challenge the admiration of the country at large, and, in some respects, that of the civilized world. It was the first great movement toward a race awakening, and from a situation like this was to come forth a leader who should rapidly scale the heights as a stimulator, leader, and exemplar.

The matter of religion had much to do with the new quickening of the race now in possession of a 


\section{LIFE OF BOOKER T. WASHINGTON}

new freedom. Two causes operated to prompt the freed slave of the South to an awakening from mental lethargy. One of these was his impulsive emotionalism and the other, the friendlessness of the situation. In his wretchedness the Negro knew God. His first, and practically universal ambition was to learn to read the Bible. Under the impulse of this initial passion the aged and the young alike thronged into the day school, the Sunday-school, and the first rude churches established by themselves. That this so largely escaped the attention of the local Christendom was due to the sway of the current passions of the period. If the current had then been diverted into proper channels conditions in the South would doubtlessly have been marvelously changed.

The ambition of young Washington had been quietly but deeply stirred by the prospective school in his community, but he was destined to profound disappointment. He had proved a valuable laborer in the manufacture of salt, always prompt, willing, active, and reliable, and his stepfather, lured more by desire of gain than by that of mental improvement, did not share in the movement for the establishment of the sorely-needed school. He sternly decided that a hand so valuable as Booker could not be easily spared from the salt furnace. The gentle mother disclosed this fact to the aspiring boy, who heard it with bitter and sullen disappointment. Still he would not give up, nor banish hope. The old "blue-back" was still his property and he would continue to delve into its hidden mysteries. The chagrin experienced was en- 


\section{A COMMON LABORER}

hanced by the passing by the furnace each afternoon of bevies of gleeful colored boys and girls on their way homeward from school, while he, a barefooted and bareheaded laborer, was toiling at the hot furnace. With a feeling of sadness he listened to their cheery laughter, and envied them their good fortune.

In slight amendment of his disappointment, in which his doting mother shared, he was able to make arrangements with the local teacher to study at night after the toils of the day were over; but even this slight pittance of advantage could not be had until he had enlisted the persuasive powers of his mother in begging the unfeeling stepfather to grant this poor chance to the boy. By plying his mother as a sort of mediator between himself and his stepfather, Booker was at last able to quit from nine in the morning till four in the afternoon in order to study at the local school. This advantage, however, was gained at the cost of unusual exaction. He had to be out of bed at four in order to hurry away to the kilns; laboring there till nine o'clock, he would then scamper away to the distant school. Though the advantage gained was in part penal for his persistency, he would turn it to the greatest possible account.

An incident which occurred in this connection is as amusing as it was pathetic. In his overweening desire to learn, he wished to gain all the time possible, and in a conflict between his ambition and his conscience, he thought of turning forward the hands of the big clock in the office by which the affairs of the industry were guided. Having done this several mornings, by 


\section{LIFE OF BOOKER T. WASHINGTON}

thus gaining additional time, it was found that the clock was running awry and the work was disturbed in consequence. Seeing that the clock had either been tinkered with or was running irregularly, the superintendent locked it away, and depended on his watch for future guidance. Casuists must determine how much moral turpitude was involved in the doubtful act of the aspiring stripling.

On entering school, Booker, by which name alone he had been known, must enroll his full name. He had learned from some source of a great man named Washington, and he thought of calling himself Booker Washington, but he felt that he must, of course, have a middle name, so he injected that of Taliaferro. $\mathrm{He}$ thus gave his full name as Booker Taliaferro Washington, by which he was afterward known throughout the world.

Another incident occurred in this connection which, though trifling enough in itself, indicated the character of the Negro youth. He had never worn a hat or a cap, and was the only pupil who went to school bareheaded. This was a source of embarrassment, and he laid his case before his mother, who told him that she had no money with which to buy a hat, nor had she any prospect of getting any. Still the lad persisted, and to satisfy him she managed to get hold of a small bit of jeans cloth, sewing the sides together somewhat in the shape of a cap. She placed it on the head of the proud possessor, and the difficulty was solved.

Not a moment was lost by the youth in his applica- 
tion to his books, but his privileges, small as they were, were soon cut off by his stepfather. To this sudden deprivation he regretfully submitted, and went into the mines as a common miner. However he clung to his books, and engaged the service of a teacher who agreed to give an hour or two of private instruction at night. Hurrying to the completion of his assigned task in the mines, he would bathe, snatch a hasty supper which his kind mother would always have in readiness, shift his clothes, and hasten to meet his teacher some miles away, remain as long as possible, return to his hard bunk, and by four in the morning resume his tasks. The spirit of hope so characteristic of his race never forsook him during those days of gloom, and he still cherished the belief that he would find a way to procure an education.

In the resounding caverns voices are easily heard, and one day while the youth was plying his pick, he overheard the conversation of two colored miners. They were discussing the matter of Negro education, and Booker overheard an allusion to a school where black youths could work their way through. Extinguishing the lamp in his cap, he crept through the gloom toward the miners in order to hear more clearly. Neither of the conversers knew just where it was, but the name of the school was Hampton. This gave fresh hope to the toiling lad. He would seek it till he should find it. He hid the information in his heart, and resolved to reach Hampton, no matter where it was.

In his eager search for the desired information, he 
learned that the school was in distant Virginia, but this did not affect either his zeal or his purpose. He bent all his energies toward the attainment of his cherished hope. He presented the matter to his elder brother, John, and the proposal was made by the brother that he would assist the younger as far as he was able, with the understanding that when Booker should complete his studies he would, in turn, assisi the older brother. To that devoted brother Booker was largely indebted for his ability to go to Hampton. John would deny himself much in order to enable the younger to get through, and he was willing to wait and labor till this could be consummated. The agreement was finally carried out, and though the elder brother was eclipsed by the splendor of the younger, he became in future years a valuable ally to Booker in his struggles at Tuskegee.

Captivated by the new prospect of the gratification of his ambition, toil to the youthful Booker now became sweet. He had visions of coming success as an educated man, for beyond the attainment of an education he did not yet consider. A perennial optimism possessed him, and unpromising as the outlook was in his poverty, he was cheered by the hope of one day being able to reach Hampton. True to the principle by which he was actuated through life, he would still labor on, hope on, and do well the tasks assigned him. "Seest thou a man diligent in his business? He shall stand before kings, he shall not stand before mean men." 


\section{IV}

\section{HAMPTON INSTITUTE}

DISTINCT purpose was now before Washington. He kept up his random studies as 1 best he could, and meanwhile continued to learn what he could of Hampton. Besides talking it over with his brother, he spoke to his mother of his plans, but she had little encouragement to offer, save to say that she was willing to do anything for the interest of her children. He was reminded of their extreme poverty and of the slight prospect of improvement. Still the lad believed that a way would yet be opened for him to go. One thought encouraged him-he had learned that at Hampton any worthy colored youth would be allowed to work his way through, and he was neither too proud nor indisposed to labor. He thought not of the expenses that would be incurred by his stay there, but was sure that if he could ever reach the school, he would find a way of pushing himself through. This philosophic disposition characterized the life of Washington throughout. He would make good the present as the surest means of future success.

In seeking to devise means for reaching Hampton he decided to apply for a position as a servant in the home of the owner of the mines, General Ruffner, 


\section{2 LIFE OF BOOKER T. WASHINGTON}

whose wife was from Vermont, and had the reputation of being difficult to please. Servants had been frequently dismissed by her, some having been turned off after remaining but a short while. However, Booker was sure he could please her, and sent his mother to solicit the job. The result was that he was engaged on trial at five dollars a week. He appeared before Mrs. Ruffner with fear and trembling, and was at once set to work. He no more closely studied his work than he did his new mistress. Perfectly docile and polite, he sought to satisfy her in every minute particular. He resolved to give the fullest satisfaction, and succeeded. Mrs. Ruffner was very exacting, but to this the boy did not object, and in subsequent years he reverted to his experience and training in the Ruffner home as elements of his success. Among the requirements was that of being scrupulously frank and honest. The exactions imposed were right, in every particular, whether of service or of character, and Booker felt that no one could object to being right and doing right. To the youth, unused to the demands of cultivated life, the drill and discipline of that home were a blessing.

For about eighteen months Washington remained in the home of the Ruffners and without the slightest difficulty. Mrs. Ruffner sympathized with his plans for the future and allowed him a few hours each day to attend school, after his tasks were done. Finally she permitted him to employ a tutor to come on the premises each day to hear his recitations.

Having saved a small amount, Washington rọ- 
solved in the fall of 1872 to go to Hampton. He was encouraged by the demonstrations of his people, most of whom seemed anxious to aid him in his worthy endeavor by giving him small sums of money, and wearing apparel. But his chief reliance was his brother. After all, he had not sufficient funds to defray his expenses for the five hundred miles to Hampton, but even with an inadequate amount, he determined to start.

With a small cheap satchel containing all that was his, Washington set forth toward Hampton, and soon learned that his money was altogether insufficient for the trip. The railway' fare was five cents a mile, and the expenses were increased by reason of the fact that at certain points along the way he had to travel by coach, which was much more expensive. But he decided to go as far as he could, and rely on the conditions of each juncture to provide for the future.

Having reached the limit of the railway from Malden in the direction of Richmond, he took the stage over the mountains, being the only colored passenger on the coach. When the coach reached a wayside inn for the night, the inn-keeper denied him food and lodging, even in an out-house. He was hungry, and the mountain air was cold, but there was nothing left to do but to tramp up and down the road throughout the night to keep warm.

Thence to Richmond the trip was attended by much 'difficulty. His purse was now empty, and he was forced, when he could do so, to beg a ride on the 
train; again he would walk or else ride on vehicles that chanced to overtake him as he plodded his way. Richmond was reached at night, and without a cent in his pocket he ventured into the city. His condition was well-nigh desperate. He had never before been in a city of any consequence, he was a total stranger, unused to the city ways, was hungry, worn, travelsoiled, and depressed. With his little satchel he tramped up and down the streets, and in his extreme hunger was tantalized by the piles of bread, pies, cakes, and fruits at the stands along the way.

At a late hour of the night, overcome by fatigue, he slipped unobserved under an elevated plank walk on the street, and, cold and hungry, pillowed his head on his satchel, and slept, though disturbed throughout the night by the passers above his head. Creeping from his place of rest in the early morning, his first thought was to find some employment as a means to relieve his hunger, and to enable him to prosecute his trip onward to Hampton, still about eighty-five miles further on. Fortunately he found men unloading a vessel of pig iron, and applied to the manager for work. He was gladly engaged, and by this means not only relieved his immediate wants but was able to make sufficient to enable him to reach Hampton.

Without further delay he went on, reaching his destination with just fifty cents in his pocket. A fresh dilemma now confronted him. The first step in the fulfillment of his ambition had been taken. But he was without means, in a strange place, where no one knew him, and where he must rely on his wits for 
future guidance. It was a crisis to the raw youth from the country.

Summoning all his courage, he went with the rest of the newly-arrived students to the office of registration. When his turn came the registrar scanned him. He had a bland face, was courteous and polite, but dirty and forbidding in appearance. A question or two was asked, but there was some hesitation on the part of the registrar, and Booker was not permitted to enroll as were the others, but told to stand aside for the present. All the other applicants being disposed of, the registrar gave him a broom, a dusting brush, and some cloths, and told him to clean a certain room. He fell to his work, sweeping, dusting, and scrubbing the surface not alone of the floor, but of every piece of furniture, the blinds, sills, and walls. The task completed, he again reported to the registrar and invited inspection. She subjected the room to the most rigid examination, using even her cambric handkerchief to test the thoroughness of the cleansing. This over, Booker was permitted to enroll. Better still, the proficiency shown in clearing up the room led to his appointment as janitor, by means of which he was able to work his way through the session.

Washington could desire nothing better than this unexpected turn of affairs. There were yet other embarrassing considerations, such as provision for clothing and books, to say nothing of numerous incidentals, but he would meet each emergency as it should arise. In these incidents was afforded 
the index of the leader that he was to become in the extrication of his people from distress. His confidence, coolness, and sanity, readiness to lay under tribute whatever was within sight that would conduce to success, temperamental equableness, force of will, high ideals, and contentment for the time with the best that could be had, were remarkable qualities that stamped the embryonic leader. Difficulty he expected, but he was ready to meet it as it came, was willing to stoop to necessity in order to conquer-in these lay the germs of future greatness alike of soul, mind, and heart.

If Washington's difficulties had only begun, the way to success was also open. The resources of his manhood would now be called into active play, and the conditions were to be such as would result in the expansion of his many-sidedness. Along with the struggle for mental development would be that of his character in the wrestle with forces in the contest for success. His mastery of difficulty here would be prophetic of his ability to grapple with the herculean obstructions which lay far in the future. The stamp of destiny was on him, though he now saw no farther than the demands of the stern present. $\mathrm{He}$ was actuated by one consuming ambition, that of procuring an education, but in accomplishing this, in his fierce struggles with penury, he was doing far more. His moral fiber was developed side by side with his gradual mental improvement. The enforced conditions of severe labor and frugality to which the youth was subjected at Hampton, would have been regarded by 
many, even of his own race, as beneath the position of a student at college; rather than undergo them, many would have rebelled. But lowliness is essential to loftiness.

"Lowliness is the base of every virtue, And he who goes the lowest, builds the safest."

At this time the odds were greatly against the colored youth. He might have sullenly pined, and in despair have said: "Where's the use, I am only a Negro." A view like this might have been at the time abundantly justified, but no obstructions moved him from his original purpose and plans. He would let the future take care of itself. The success of the present was to him sufficient for the time, and to make that secure would be a guarantee of future success. This was his abiding motto through life, as was abundantly illustrated later during his struggles at Tuskegee.

The work of the janitorship was heavy and exacting. Often he might have been seen panting from his excessive labor, with his broom resting against him, mopping the perspiration from his face, while there was the pressing demand for preparation for the classroom; but he was confident that he could master the difficulty in some way. Reduced to the extreme of poverty, he had to make every possible makeshift in order to make ends meet. He had but one suit, which was often soiled by labor and yet it had to be clean for inspection each day. An only pair of hose had to 
undergo a daily laundering at his hands. Uriable to buy books, he must borrow from such students as were willing to lend. The lot of no one could have been harder.

To the rough youth from the plantation and the coal mines, who had never known comfort, the conditions at Hampton were extremely odd. Neither on the plantation nor at the mines had he ever slept in a bed. A hard bunk or a pallet of rough straw had been his bed from babyhood. Even stated hours for meals were to him a novelty. Knives, forks, and spoons he now used for the first time. Sleeping between sheets was to him at first amusing and seemingly unnecessary. The great buildings, large and commanding, with their various departments, were to the raw youth astonishing. But every scene was one of inspiration. Not a waking hour was to be lost. The double task of the janitorship and preparation for the classroom, was daily his. He was possessed of the ambition both to hold his place in his classes and to perform his work of drudgery well. Others might find time for recreation on the playgrounds, or lounging on the seats under the shade trees, but he must continue his work, either with his books or his brooms and brushes. Still he never repined, but wrought with a spirit of cheerfulness throughout.

His thought was all the while engrossed with the concern of duty well done. There was never cessation of work, but to this he was inured by past experiences; and no temptation could lure him to negligence. The labor performed was enormous, but he was able to do 
it. Throughout he was quiet and reserved, never obtruding himself on the attention of any, but uniformly courteous and polite, and by this course he won his way to favor, not only of the students, but of the officers of the school. Best of all he attracted the attention of the faculty. It was seen that in the uncouth stripling there was an element of rareness. His exact compliance with duty, of whatever character, first won attention and then sympathy. He was dutiful above most others, unceasing in labor, intent on cleanliness, and so studious withal, that teachers began to aid him by gifts of small sums of money and by special personal assistance. It did not escape the attention of the teachers that this unusual and exceptional student was embarrassed by his engrossed attention to that only suit of his. It was duly observed how embarrassed he was to preserve his outfit from inevitable threadbareness, and at the same time subject it to constant scrubbing and cleansing. It was a conflict between two practical laws, the perplexity of which he could not well master.

There was one element in the character of young Washington which is perhaps the most exceptional and indispensable one to success of any, and that is, subordination to authority. This he yielded, not from policy, nor with sullen reluctance, but readily, from a sense of duty. One of the most comprehensive of the virtues, when this obtains, it compasses other and lesser virtues. Where prompt obedience to authority is merely mechanical and is rendered for temporary advantage only, with the spirit of proper subordination 
absent, one becomes insincere, sordid, shriveled; but where it is accepted as unquestionably right, and obedience is rendered in exact proportion to requirement, the character necessarily expands in nobleness. Had there been no other element in this young Negro, that one was a sure guarantee of success.

Immense was the gain made by Booker $T$. Washington when he attracted the attention of General Samuel C. Armstrong, the Principal of the Institute. General Armstrong had been an officer in the federal army, and he applied the rules of the camp, in many particulars, to the management of the school. In founding the institution, he had promptly recognized the necessity of rigid discipline in molding and shaping the leaders of the colored race as it then was. Laxness, slovenliness, indifference, he would not tolerate, and he was the more determined to exact their opposites at that time, than he might otherwise have been. It was the first school of that character established for the race in the South, and he would set a pace for the future. In addition to his military exactness were his profound kindness and disinterestedness. In him were blended just the qualities needed for an important initial venture like the one at Hampton. Born the son of a missionary to the Hawaiian Islands, he inherited in rich measure the evangelistic spirit of his parents. Graduated from Williams College, in 1862 , he became a member of the 125th regiment of New York Volunteers, where he rose from the rank of captain to that of colonel. Later he commanded a colored regiment, won distinction for gallantry, and when 
mustered out of service it was with the rank of brevet brigadier-general.

At the close of the war, an immense population of blacks, wandering and aimless, gathered in Hampton, and General Armstrong was impressed with the importance of founding a school there, to meet the immediate and future needs of this unfortunate people. Enamored of the enterprise from the beginning, he gave his life to the task. Far too little is known of this pioneer hero in a cause so timely. Whatever may have been thought of him at that time, General Armstrong was a benefactor to the entire South. The results of his labors have been reaped in all the states of the South in the equipped men and women whom he sent out as torch-bearers to a benighted people. Gallant as General Armstrong was on the field, he was braver to assume a task like this and at a time like that. He was emphatically a benefactor alike to both races. Facing the fiercest passion at the time, he calmly wrought and nobly achieved. Fortunately time has so toned passion that today he is regarded somewhat in proportion to his just desert.

Brought into interested contact with the raw but unusually promising colored youth from West Virginia, General Armstrong thenceforth became increasingly interested in him. A man of affairs, a student of character, and favored with wide observation, he was much impressed by the struggles and sacrifices of young Washington, whose exceptional spirit became a source of hopeful inspiration to this pioneer racelifter. He quite understood how easy it was to delude 
those unsuspecting young people with a thin veneer of education, and he was resolved on the rigid exaction of duties that related to the fundamental necessities of the black people in their outset on life. He studied with rigid incisiveness those of the colored boys and girls who gave promise of future leadership, and, often subjected them to tests of which they were unaware. Washington did not know at the time, that General Armstrong had discovered in him unusual qualities, and that he was keeping a close watch on his conduct in order to the future usefulness of the young man. But General Armstrong was the force behind the successive stages of Washington's future career. 


\section{V}

\section{THE GENIUS OF HAMPTON INSTITUTE}

7 HE interest organized and fostered by General Armstrong at Hampton, was wisely adjusted 1 to the principal needs of the colored race.
Nothing could have been more sanely conceived, nor more properly and wisely conducted. The school was not merely for the training of the minds of the young. The mere development of the minds of the colored youth at that time, would have resulted in top-heaviness and lop-sidedness. So far from rendering practical service to these people then, it would have more unfitted them for adjustment to the practical affairs of life. Not mind alone was sought to be developed at Hampton, but character, as well. This was the complement of the purpose of this Christian philanthropist in giving his life to the service of these people. They needed proper formation of character, right views of life, the full meaning of duty, and a just appreciation of manhood and of womanhood. In order to such attainment, General Armstrong introduced into the school the regulations of the camp.

Nor was this sufficient, for the exercise of the gentler virtues was just as essential to the full accomplishment of the purpose in view, as mere drill and 


\section{LIFE OF BOOKER T. WASHINGTON}

discipline on the sterner side. Firmness coupled with kindness, exactness with liberty, and patient drill in order to the development of body, mind, and character, were just as necessary as rigid regulation. It was a source of continued encouragement to General Armstrong to see how readily these requirements were complied with by the crude elements coming to the institution from the huts and hovels of plantation life.

The standard of requirement was productive of most salutary results. It produced a beneficent atmosphere, for it came to be a principle at Hampton that one must not only be a recipient, but a dispenser, as well. The spirit of the school was one in which there was exercised proper interdependence-mutuality of help. As the pioneer leaders of an undeveloped race, the young men and women thus fitted at Hampton would be able to erect a standard of life for their people. From the time of his entrance into the institution till his retirement, each was impressed by this principle. He was helped in order that he might, in turn, help others.

The first year at Hampton had been passed by Booker T. Washington. He had entered the school with the barest rudiments of technical knowledge and with but slight acquaintanceship with the ways of the world. The little that he had previously acquired was angular and irregular, and needed to be brought into symmetrical shape, and made consistent with much else required by the course at Hampton. As already seen, he was beset by severe difficulty in providing 
means of self-maintenance during the year, but, somehow, he had been able to reach the close of the first session.

The year had wrought a marvelous change in the young man. While none the less intent on his educational purpose, he now had an entirely different view of its application. His ideas had been limited to the attainment of knowledge, and he had had no specific end in view. To what he would devote his life had not occurred to him. After the close of the first year at Hampton the boundary of the once near horizon had been pushed back. He now breathed a different and purer atmosphere, and things did not seem as in former days. His ambition to accomplish the most possible in text-books, instead of being slackened was increased. There had come into the life of the stripling new purposes, chief among which was the desire to acquire qualifications sufficient to enable him to aid his people in deliverance from their peculiar situation. Just how this was to be done he did not know, but the study of their condition and acquaintanceship with their needs had aroused this new desire. This he had received at Hampton.

It is not easy to appreciate the nature of the difficulty involved in the undertaking of General Armstrong and his associates at Hampton. Only the most skilled instructors could equal the demand of that peculiar situation. The work done was both educational and evangelistic, both preparatory and directory. Young slaves who had grown to incipient manhood and womanhood, in the presence of a civilization 
in the benefits of which they were only the slightest recipients, must be qualified to enter that civilization at an advanced stage. Not only so, but as the vanguard of their race in an anomalous era they must be able to establish a standard of life worthy of a great people. To assume thus the transformation of a large mass of young ex-slaves who would bring with them to the school their rude plantation characteristics, and to knead this mass into respectability while at the same time inculcating the principles by the exercise of which they must become race-lifters, was a task worthy of any man. The means by which this difficult work was done were subtle and ingenious. There was no bewailing the condition of the colored race on the part of the teachers, nor any appeal to the emotional side of the colored pupils, nor yet driveling admonitions on piety and religion. But the regulations and requirements of the institution were pitched on a plane so high as to create a condition from which came the beneficent and manly spirit which pervaded Hampton throughout.

Everything taught and done had reference to that which was expected to be taken away from the institution as a guide to future life. Students were impressed by the fact that the advantages which were theirs were denied millions of their race who were altogether as worthy as themselves, and that they must go to these as inspirers, lifters, and helpers. It was this influence that had thus turned the thought of young Washington into a new channel. It gave purpose to life, and seriousness to work. He would 
henceforth meet at each step new suggestions of value for that which was to come.

Right on the grounds of the school there was daily exemplification of these principles. While the officers and teachers governed, and taught, and rigidly enforced the regulations, they did so with an air of helpful interest. The spirit was not difficult of inculcation, therefore, because it was communicated from every source of authority to the humblest pupil on the grounds. In consequence of this, so thoroughly imbued became the students that they would often reduce themselves to straits of sacrifice in the interest of others. Without this, the poor stranger from West Virginia could not have advanced. As already stated, he was at first forced to borrow the books from which to study. He was the janitor, often seen with his broom on his shoulder about the buildings and grounds, and the favored treated him with the cordiality of an equal. Not only books were lent, but small sums of money among the students; the sick were cared for and tenderly nursed, and when arrival of fresh installments of students over-ran the limits of accommodation, the students already settled would willingly accept scantier comfort by the surrender of their rooms, and by going into improvised quarters of tent life, till better arrangements could be made. This was invariably done in a cordial and cheerful spirit.

Qualities like these developed in the future leaders of the race were destined to immense effect, in a variety of ways. There was current at the time the 
idea that education would spoil the Negro, unfit him for usefulness, and give him a sense of consequence that would invite friction. The education inculcated at Hampton was, and still is, a complete refutation of this theory, which is as groundless as it is ungracious. Nobody ever saw a Negro "spoiled" by real mental development and genuine culture. Harebrained individuals of the race, there doubtless are. Those who mistake a thin veneer for solid mahogany are just as apt to be supercilious as the same class of any other race, and no more. So far as superficiality goes, observation teaches that no race can lay claim to monopoly. Most of the students who have gone out from Hampton, Tuskegee, and other great colored schools are a thorough refutation of this prejudicial fling.

Washington's painful experiences were not yet over. The close of the first session brought glee to the students who were leaving for their homes in the different states, but the youth from the salt pits of West Virginia had no means with which to return to his distant home, and, more, he had no means of subsistence to be anywhere. Anxious to get away to obtain work, he sought to sell a second-hand coat for three dollars, but those who wished his garment were unable to pay for it. With clatter and laughter, the boys and girls were leaving, the doors and grounds of the school were closed, and silence supreme came, and Washington had to go somewhere, he knew not where.

Finding at last a job in a restaurant at Fortress 
Monroe, he entered on his work, but the wages were extremely low, being slightly more than enough to defray his cheap board. The session had ended at Hampton with the encumbrance of a debt of sixteen dollars on him, and this he was anxious to cancel. To him sixteen dollars was then an enormous amount. The debt preyed on his high sense of honor, and to pay it was to him a consuming desire above all others. He worked hard, scrimped, lived in a most niggardly way, did his own laundrying, went without needed clothing, and turned an honest penny whenever he could, but he could not get ahead. It mortified him to think of returning to school for the next session with indebtedness of the former session still unpaid, but it seemed inevitable. One day someone inadvertently let fall under one of the tables of the restaurant a new, crisp ten-dollar bill, and on finding it, Washington was much rejoiced; but he felt that he should report it to the proprietor, as it was picked up in his place of business, presuming that he would gladly let him keep it, but instead, the owner himself laid claim to it because it was found in his restaurant. The act of the proprietor is its own commentary.

Vacation over, and with but slight means in his pocket, and the debt of sixteen dollars still hanging over him, Washington wished to return to Hampton. He was humiliated, but not unto despair. He would not give up. $\mathrm{He}$ had met severer difficulties, and while it was embarrassing, he would face the situation. After a frank statement to the treasurer, and the proposal to cancel the debt by extra labor, the 
matter was settled, and he entered on the second session with increased confidence and zeal. Much to his delight he was continued in the chief janitorship of the school, than which he desired nothing better. Relieved of some of the handicaps of the previous session he felt that he was now prepared to do the best work of his life. There was no longer novelty respecting any feature of the institution. He fully knew what was expected of each student, he had learned how to economize time in his labors, he had acquired fixed habits of study, and in spite of his poverty, none was more cheerful.

Booker T. Washington was now about sixteen years old, yet the immature youth had already become much concerned about the fate of his people. His experience as one of the lower class, coupled with the enlarged views which he had gathered at Hampton, deepened his solicitude, especially for the Negroes in the rural regions of the South. The questions often arose, "What is to become of the Negro, anyway? Where is the hope of subsequent relief? How can he possibly emerge from the incubus under which he is?"

Within the school there was no one more familiar with the deep poverty of the black man, none who better knew his condition mentally and materially, and none better prepared to sympathize with him in his dejected state. Coextensive with the growth of the thought of the youth was that of sympathy for his people. It is not difficult to see how, as a result of the conditions now centering about and within the life of Booker T. Washington, he should finally become the 
great race leader. Long after he left Hampton, he made a published statement which reveals equally the character of Hampton and the new purpose which had come to possess him. He said: "The education that I received at Hampton out of the text-books was but a small part of what I learned. One of the things which impressed itself upon me deeply, the second year, was the unselfishness of the teachers. It was hard for me to understand how any individuals could bring themselves to the point where they could be so happy in working for others. Before the end of the year I think I began learning that those that are happiest are those who do most for others. This lesson I have tried to carry with me ever since."

Notes, or data, kept by him at Hampton reveal the fact that in proportion to his increased fitness for future work, grew his chafing to get abroad in the world that he might become somewhat a means of helpfulness to others. His chief concern was his mother. She was long an overworked slave, and there had been no diminution of her labors since the dawn of emancipation. Indeed, if there had been change, her lot was the harder now, since in her devotion to her children she toiled but the more to lift them to heights which she was destined never to enjoy.

Among the numerous advantages afforded Washington at Hampton, was that of drill in speaking, or declaiming. He was highly favored in having so efficient a teacher as Miss Nathalie Lord, of Portland, Maine. Miss Lord was among the many scholarly missionaries who went South when colored schools 
were established, to aid in teaching the colored population. Denounced as fanatics, as this class was for years, no missionaries in the early days of Christianity exceeded them in devoutness of spirit, loftiness of purpose, and the amount of needed service rendered. Washington aspired to become a public speaker, for which he had peculiar gifts. The ease of manner and quiet poise which so distinguished him later before large audiences throughout the country, as well as the thoroughly modulated voice, with penetrating power, were the results of his cultivation at Hampton.

At the close of the second session of school, Washington found himself able to return to his home at Malden. This coming back to his former haunts among the salt kilns and coal mines was the occasion of a mild sensation among his people. Two years before he had left them a rough, unhewn stripling; he had developed much physically, and otherwise was vastly improved. He returned the cordial greetings of his old-time friends who alluded to him with pride as " our boy." In the rough hospitality so generously extended, he joined appreciatingly; each home would assert a special claim for a given night when he was to come and tell of the ups and downs of his experiences since he went away. The colored people have a peculiar passion for public speaking, especially by one of their own number. So Washington must be heard again and yet again, the attention being the more riveted since they recalled him as an urchin of former years going in and out among them bareheaded and 
barefooted. Sunday-schools, churches, and improvised special occasions afforded to him the amplest opportunity for public speaking.

While all this was gratifying to the young man, he had an eye to business. He wanted work. The summer was slipping past, and he had yet another year to complete his course at Hampton, and that meant money. But no employment could be had. A strike was prevailing, the furnaces no longer smoked, nor was the pick active in the mines. While away for a day from home, he received the news of the death of his mother.

Among the characteristics of the colored race may be named as one of the most dominant that of the devotion of the Negro mother to her children.' One must know the race to be able to appreciate this artless and unaffected love. Were she a mother of any other race than that of the Negro, her singular devotion would find expression in "the flower-crowned annals of song." The abiding tradition of the "old black Mammy" in the records of the South is an illustration of the supreme tenderness of the affection of the colored woman for the young. The old "Mammy" is immortalized by reason of her vital touch with the children of a dominant race, but that affection is only an index of that which she bears for her own children. The world has yet to come to a proper appreciation of the value of Negro motherhood in the promotion of the good of their children. Thousands slavishly labor at the washtub, in the field, and in various household functions, often in the most 
menial ways, simply to advance the condition of their children. As men like Booker Washington have risen from disadvantage of race, and from deep obscurity to prominence, they have never lost sight of the fact that their mothers were the chief and primary causes of their success.

The vacation was going past and rapidly; a month was already spent, and Washington could still find no employment. At last, Mrs. Ruffner, who had kindly united in the salutations to her former servant-boy, gave him temporary employment, after which a distant coal mine enabled him to find additional work. In all his varied experiences and needs, Booker Washington never failed to find an abiding friend and cordial helper in his brother, John, and never did he cease telling of that brother and of his unstinted kindness to a brother whom he found pride in aiding. In the discovery of the dawning greatness of the one, the other was willing to sink himself out of view in his disinterested assistance.

With the odds against him, it seemed at one time during the summer vacation, that Washington would have to give up all hope of returning the following session to Hampton. But the unselfish brother John came again to his rescue, dividing with him his scanty wardrobe, and, by supplementing the slender contents of Booker's purse, enabled him to see the way open again to Hampton, for the last year.

Fortunately, several weeks before the session was to open, Washington received a letter from Miss Mackie, the white lady principal, the same who on 
Booker's application to enter Hampton gave him a broom and dusting-brush to test him, as there was nothing in his personal appearance at the time to commend him. This lady wrote him to come on several weeks in advance of the opening of the session, to aid her in getting the buildings and grounds in shape. This was a fortunate rift in the gloom. The labor meant an advanced balance in the college treasury at Hampton. At the appointed time he was on hand with cheerful spirit, ready to do the bidding of the lady principal, and so he entered on his last year at Hampton.

Though a senior, Washington was still the janitor, working his way as he had done from the first. By this time, his merits as a student as well as a janitor had come to be fully recognized. He was regarded as one of the most laborious of the students. He had a strong, well-knit frame, was inured from childhood to hard service, possessed an equable temper, never fretting nor chafing, was ambitious and untiring; he absorbed suggestions and hints from all his surroundings, was careful in the mastery of every detail of school work, whether of his books or in the service rendered as janitor, found an abiding pleasure in cleanliness and neatness of person, had a growing consciousness of his forces without show of vanity or of arrogance, was notably courteous to all alike, and among the pupils was regarded as an ideal student. In the student body he came to be recognized more than any other, as the readiest man for all occasions and special events. Everyone trusted him for his 
sterling integrity, and with all, both among faculty and students, he was popular because of his uniform. temperament, affableness, and jocularity.

To special students in the graduating class there were accorded certain honors, one of which was the distinction of delivering graduating addresses. This distinction he coveted, but it was based on merit of scholarship. Yet in spite of all handicaps, he won the coveted honor, and was graduated in June, 1875 .

By dint of hard labor, both manually and mentally, Washington had reaped the honors he had so long desired. Added to his mental acquirements was a fund of practical knowledge rarely possessed by anyone on quitting college. He had often struck the hard sides of life, but was the stronger and the better therefor. He was just now budding into manhood. A severe strain of life of which he now little dreamed was before him. The commission to leadership of a race of millions had not yet been given him, but the forces were accumulating in his character and flowing into his life, and in due time an effectual door of opportunity was opened. 


\section{VENTURES INTO THE WORLD}

A 1 the retirement of Washington from Hampton, was not hailed with an ovation. Race aversion was at its height, and Negro merit was not only discounted, it was discredited, especially in the sphere of scholarship. The more meritorious he might be for scholarship the more pretentious was he considered. The times were altogether unfavorable to the educated Negro. A colored man was accounted "good" in proportion to his conformity to the oldtime requirements of slavery. One was "a good Negro" if he suffered the imposition of heavy tasks with slight compensation, and would submit to any disposition without protest. At this time, too, colored schools were regarded with suspicion, servants were poorly paid, and the common laborer among the blacks was often mercilessly swindled.

These were some of the conditions extant in 1875 when Booker $\mathrm{T}$. Washington graduated from Hampton. It was the period of reconstruction, of which to read only is to gain but a slight idea of its terrors. It was more aptly the period of the victimized Negro. Like a shuttle in a loom he was tossed to and fro between the two classes of contending whites, and it 
would be difficult to decide which was the stronger, the antipathy of one class, or the passion for spoils on the part of the other. Between them, however, the Negro was the victim. Being suddenly invested with the franchise of the significance of which millions of the race knew nothing, the occasion was seized on by a host of harpies, in the contribution to which both the North and the South shared, and the period was turned to the sad and lasting detriment of the Negro. From sordid selfishness, one class would incite to undue assertion the innocent and ignorant black man; this would often be fiercely and violently resented, and while the instigators would skulk in safety the misguided colored man was made to suffer indescribably. Vengeance and violence ruled the hour and turbulence and terror filled the land. There seemed no possibility of relief, none of race adjustment when both races were suffering, none of calmness and of conservatism. The times were out of joint, race relation was distraught. Only to show the peculiar times in which Booker $\mathrm{T}$. Washington began his career after quitting school, is this dreadful period of reconstruction recalled in this connection. It would have seemed impossible for a colored man even measurably to accomplish that which he achieved within the next few years. Least of all would a Negro, at the time, have been thought of as one who could contribute to the solution of the tangled racial conditions of the period.

With a keener insight into the situation as he neared manhood, Washington saw but little to cheer, and 
but slight chance for the Negro. No freedom of utterance was the black man's, no protest could he raise, no matter what the imposition; and with hostile passion so prevalent, with the easy versatility of mankind in the mass existing, the Negro seemed doomed. When he came out from college into the world, he started back in horror to learn of some of the atrocities perpetrated on his people. The intensity of the passion of the time was such that even the latent white friends of the Negro, thousands of whom were bound by traditional ties to the one-time slaves, dared not lift a finger or raise a voice in protest lest the blows fall on their heads. It was a time like this when the future race-deliverer left Hampton with his diploma.

Washington entered on life as he had several years ago entered school-without a dime in his pocket. It had been a struggle with him since first he had felt a rising ambition to accomplish something of worth. He was now somewhat ready for the rough encounters of the world, but he was balked by existing conditions. There was not the slightest encouragement in any direction. But he must be engaged in something. He was not above the most menial service if only an opportunity would offer for work. It was the dull season, and he thought of some watering resort where he might find employment for the time. Unable to find work in the South he sought the East, and at a fashionable summer resort in Connecticut, he engaged to serve as a waiter in a hotel. The work was new and untried, and he was awkward in his new 
vocation. The fashionable ones at a certain table assigned him, were severe in their denunciation of his deficiency, and he fled the dining-room from sheer fear. He willingly accepted a subordinate place as dish-carrier, for this he could do, while learning the ways of the resort and acquiring from observation that which made a successful waiter. When he found that he could successfully move in the groove required, he again assumed the rôle of waiter with decided success.

The season over, Washington accepted the position of teacher at his old home at Malden. This was the same school which he attended in former years as a barefoot and bareheaded boy, and from which he was so suddenly and ruthlessly withdrawn by an ignorant and unsympathetic stepfather and assigned to work in the mines. While the school had grown in size, its character was not changed. Inefficient teachers had been unable to classify the motley group ranging in age from the smallest child to matured men and women, so that the first care of the new teacher was that of the reconstruction and classification of the school, and his next, that of the personal condition of each. The pupils were generally indifferently clad, and wore their clothes in a bungling way; there was a demand for much soap and water to be applied to their persons, their teeth had never known a brush, their hair never a comb or brush, their shoes were shabby and often stringless or untied, and there was work for the young civilizer as well as for the teacher. A brief time was all that was necessary to bring into 
the schoolroom a complete transformation. There came a pride to each pupil as was shown by a neater appearance, the boys now wearing cravats, and the girls with rosebuds or bits of ribbon in their hair; the books were no longer soiled, the floor was kept clean, order and quietude came to possess the school, and thus Malden became a dim index of future Tuskegee. The home life of the community was also changed. Whitewash was given the fences and the humble homes of the black people, flowers were planted about the little homes, and other signs of improvement were evident. If the schoolmaster was abroad, so was the civilizer and reformer. With kindly aid the young teacher was here and there, with advice and sympathetic interest. Backward students were sought out in their homes at night and helped over difficulties, an occasional old man or woman who wanted to learn to read, was aided, the sick were visited and cared for, and wherever there was needed service that he could render, it was given. The Hampton ideals were equaled as far as practicable, and the colored population of Malden was undergoing a great change.

This was the first opportunity afforded him for giving expression to the sentiments cherished while he was a student at Hampton. Much of the colored population in the region of Malden was degraded, as a result of the mining operations of the section, and thus a sphere sufficient to enlist all the forces of thought, time, and energy of the young civilizer was afforded.

The condition here witnessed suggested to Wash- 
ington the comprehensive needs of his people everywhere. That which he saw in the neighborhood of his original home was necessarily true of the condition of the colored people throughout the country. If by the infusion of even slight aid the spirit of the people could be aroused, as was shown at Malden, what might be the result of a general movement of the kind? He found the people encouragingly receptive and responsive, and if a system could be devised by means of which the masses of the blacks could be reached, the most wholesome and salutary results would follow.

He appreciated the fact of the existence of serious difficulties. There was a sentiment altogether unfavorable to Negro development. The common estimate of the whites throughout much of the South, concerning the Negro, was quite low. The result of the reaction of this spirit largely disheartened the Negro, often demoralized him, and had not a little to do with depressing him toward the straits of criminality.

The opposition to the Negro at this time was enhanced by the appearance of certain pretentious publications which appealed to the worst passions of the time to the financial advantage of the authors of these notorious effusions. The earliest of these to appear was called "Ariel," and it proposed to show that the Negro was the serpent that beguiled Eve. By ridiculous assumption and a pretense of scholarship this small but bitter pamphlet appealed to race prejudice at a time when it was most sensitive, much to the detriment of the ignorant Negro. "Ariel" was 
equaled in its preposterousness by still another pamphlet which soon after appeared under the title, "The Negro a Beast." The title indicates its character, and equally its sole design. While for some reasons these are unworthy of respectful notice, they are now recalled in connection with that particular period in order to show the temper of the times. These worthless and absurd publications, while ridiculed by the thoughtful, had the effect of generating passion in the most inflammable element of the whites.

Then came the period of the Ku Klux Klan, and whatever merit may attach to the claim that this organization was necessary in order, in popular parlance, " to keep the Negro in his place," certain it is that it was diverted to much abuse, by unworthy persons employing it for reasons of violence against the former slave. Such was the awe and sense of insecurity in certain quarters of the South that no Negro knew when he might become a victim. Whatever else may be said of the work or purpose of this organization, it left in its wake the recrudescence of savagery known as mobocracy.

The peculiar elements entering into this period are recalled in order to indicate the inauspiciousness of the time for the entrance of a young ex-slave on the work of race reformation. The two races, the whites and blacks, were cloven asunder in mutual distrustfulness, and any point of racial contact seemed most remote. Nor was it yet contemplated by Washington that he would undertake other work than that he was doing at Malden. His work, first of all, had to be 


\section{LIFE OF BOOKER T. WASHINGTON}

fundamental and adjusted to the conditions then prevailing. No one had yet appeared who was able even to indicate what the preparatory work for these people could be. It was widely hinted at, at Hampton, but a Hampton could not be located in every community, and there must be means found for the dissemination of the wholesome principles there suggested. Hampton suggested the principles, but the application of these to the millions scattered through many states was not so easy. This way was yet to be discovered. The ex-slaves had to be taught certain rudimentary elements of civilization, without the possession of which they could not begin the upward climb of racehood.

Not least among these was that of the essential meaning of an education. Generally speaking, they had emerged from slavery a grossly ignorant mass of humanity. In slavery their ignorance was accounted as one of the indispensable adjuncts to service and usefulness. For them to have learned the history of their servitude and of the efforts made by the abolitionists to procure their freedom, would have engendered restlessness and perhaps revolution. The sole security of slavery was, therefore, dismal ignorance. In order to this, means of information must not only be withheld, but the heaviest penalties imposed by law on any who dared to give them instruction. Here was encountered the same difficulty as that encountered by the Moravians, who were the first to give the gospel to the Negro, when their missionaries went to the West Indies. For teaching the gospel to the igno- 
rant black laborers on the sugar plantations of the Indies, the two original missionaries, Dober and Nitzschmann, were imprisoned. William Carey met the same obstruction as a missionary to India, when from motives entirely mercenary the British East India Company sought to suppress him in his efforts to evangelize the people. This was the condition in which the emancipated man of the states of the South emerged from servitude.

His original idea of education did not exceed that of personal satisfaction. Beyond that he did not at first peer, for he was incapable of doing so. He had to be taught that education was a means to a useful end. Happily he was eager to learn, but it was that he might read the newspapers and the Bible. There was a time when even Booker Washington placed no higher estimate on the acquisition of knowledge than just this. Independent of wise and progressive leadership, the race must have remained in this condition. But the leader was in process of preparation, and from the gathered store of suggestion from Hampton, he was already beginning to apply at Malden the principles there gained. That which he later achieved was only a vast expansion of the embryonic efforts which he made in the little town in the Kanawha Valley. He had to teach his people that in the ultimate outreach of an acquired education the object was one of race and of world-wide beneficence.

The other necessary element of civilization, the knowledge of which the freedmen of the South had to acquire before the race could fairly start on its ascent, 
was the meaning of a home and of home life. In estimating the progress made by the Negro since his freedom, but slight notice is accorded to that of his rapidly-improved idea of home life; yet it is one of the highest evidences of his advancement. At his emancipation the ex-slave was practically without the idea of familyhood. Proverbially affectionate as the black race is, as shown by its loyalty and devotion, this sense of home-life had been made to suffer in slavery along with the debasement of all other virtues. The germ had to be touched into vitality, and as it sprang into life, it had to be directed. The slave knew nothing of real home-life. The elements which enter into that life, unity as well as diversity, the tenderness of care, the love of the old place called home, the discipline of parents, the variety of affection among the different members of the home, and all else that really constitutes home-life, were practically unknown to him. He had no home. He had an abiding-place which to him was much like the perch of the fowls, or the barn to the home-coming brute at the close of day. That was not a home where the chief elements of furniture were a hard bunk or two for a household, a few backless stools, or inverted boxes on which the tired slave could sit. Nor was it a home where the family might at any day be dismembered by the sale of the parents or the children, occasioning sometimes such separations that the families were never again united. One of the primary essentials of the exslave was that of learning the meaning of home.

The proverbial fondness of the Negro for early 
and sacred associations invested the little cabin home on the old plantation, and the burial place of his dead in the little clump of trees hard by, with a reverence that was remarkable, but it was not because of the joy of home-life there experienced, but rather because of sad memories. The idea of home had first to be generated among the emancipated blacks, then would follow the thought of making it comfortable and attractive. How readily this could be done was illustrated to Washington at Malden. Realizing the moral influence of the ownership of a home and of lands, he continued through life to urge this upon his people. Ho insisted, and rightly that a landless people are a dependent people, and that the Negro, in order to rise in the scale of excellence, must own his home and farm. By thus combining the two essential ideas of home and the true meaning of education, the Negro was ready to enter on civilized life, and not till then. For generations he had been living within full view of civilization, had gazed on it as an idle spectator, without the opportunity of appropriating it, but now that the opportunity was his, the coming leader saw that without proper training the race would continue its vague blundering. To the extent of his opportunity, he was demonstrating his idea at Malden.

It will be readily seen how stupendous was the task that awaited Washington within the next few years. The race was in confusion. Some white teachers and missionaries had come southward to enlighten the late slave, but they were without the advantage of understanding the Negro in his depressed condition, and 
while their service was valuable, only one who had been through the tribulations from slavery all the way, was able to weld the race into symmetry of sentiment and of life. Hence Washington was raised up.

The conception of real life derived by Booker $\mathrm{T}$. Washington, at Hampton, was a revelation, for, as Lessing says, "Revelation is education coming to the human race." It is just as true that education is revelation. These cardinal ideas, once possessed, would put the race into the way of procuring other acquisitions relative to the true life of a home and a true conception of life.

Washington had no patience with the Negro possessed of an assumed sense of personal consequence and importance, with nothing else to indicate it than a flashy cravat, glazed shoes, a jaunty hat, a long coat, and a cigarette. Himself intensely practical, he sought to impress this lesson on all others of his race, and to this end labored till the summons came at last. This led him, whether in his instruction in the classroom, on the platform, in the council, or as a visitor in the homes of his people, to dispel certain erroneous notions which came early to possess so many members of his race. His work was many-sided. Though himself not a minister, he often found it necessary to dissipate the ideas of many who claimed to have a certain mysterious " call" to preach, which, especially in the early stages of freedom, sought expression in a stentorian roar, stamping the floor with the feet, and frantic and frenzied action. With unsparing criticism he attacked this and much else, in his own inimitable 
way, and exposed its folly. His example as a public speaker, calm, poised, self-possessed, simple, logical, and direct, set a pace which subdued much of the extravagance of the clerical tyros of his people.

At Malden his sphere was limited, but then he was quite young. With him as with every other genuine teacher, while he taught others he was really learning more than they. Numerous were the erroneous tendencies checked by this chosen leader. That which was his, he imparted, and so practical and timely was his wisdom, and so aptly expressed in every way, that he was heeded. He never ceased to urge that knowledge is an acquisition to be practically wielded, as one would use an instrument or an implement. To have and not to use was clearly an abuse. Thus he regarded with contempt those of his race who were pedantic, and who, in disregard of the essentials of their own tongue, strove for a mere smattering of the ancient classics in order to excite the wonder of the ignorant, recalling the quaint lines of the English poet :

"For many a lad returns from school, A Latin, Greek, and Hebrew fool; In arts and knowledge still a block, Though deeply skilled in hic, haec, hoc."

It was not that Washington undervalued a knowledge of the classics, for he highly prized it, and rejoiced in meeting a really learned black man, but superficiality coupled with assumption he profoundly despised and stoutly opposed. His risibles were now and then aroused by meeting one of his race with a 


\section{LIFE OF BOOKER T. WASHINGTON}

scholastic veneer and a superficial varnish smeared -over an ignorant surface. He regarded with sincere pity men of his race who in the misguided period of reconstruction were raised to positions for which they were not qualified, and who, in subsequent years, bore their original official titles while performing the most menial service.

From all distorted notions he sought to divert the attention of his people, and in order to save them from the misconceptions of life he would insist that each begin at the lowest rung of the ladder, and ascend as rapidly as he might. He sought to show that there was no nigh-cut in education for anyone, and certainly not for the Negro, and that merit would be as readily recognized by those whose judgment was worthy, for the genuinely deserving colored man, as for any other. In substantiation of this view he would point to men like Senator B. K. Bruce, of Mississippi, an acknowledged statesman; to Henry $O$. Tanner, the great American painter, and to Paul Laurence Dunbar, the bard of the Negro race, all of whom received recognition because none could deny their claims. Men like these were frequently pointed out by Washington as ornaments of the race, men who would be prized by any people, because of their genuine value. 


\section{VII}

\section{IN THE VESTIBULE OF HIS LIFE WORK}

W

ITHIN the narrow compass of the small work done by Washington at Malden, we see the blossom which was prophetic of the coming fruit. The magnitude of that which was there done is not to be measured by its restricted limitations so much as by its predictive significance. He was seeking to do nothing great, and he did not, at Malden, only as that done related itself to his future career. Malden was Tuskegee in embryo. He infused his spirit into not a few of his own race there, fitting a number for entrance at Hampton, among whom were his devoted brother John and another of his brothers. The vision of service had been caught at Hampton, and in a modest and most unpretentious way, he was conforming to that vision in this his earliest effort. Each step upward threw back the horizon and widened the prospect. At the time, he was not aware that he had found the clew which, when followed, would lead to the heart of the chief difficulty by which his people were encumbered. Hitherto the clew had not been discovered, nor by anyone even remotely suggested. Regarding the situation generally from without, and casually, the wisest and best thought of it only as a "problem." 
By the sudden turn of the wheel of revolution a vast jumble of incoherent elements had ensued, presenting a spectacle to civilization such as the world had never before seen. The situation was one not only tremendously novel, it was overwhelmingly perplexing. If the race recently freed was confronted by difficulty, no less so was the dominant white race. The freedmen were in the South in massed millions. What was to be done with them? To expel them, even if such a thing were possible, would be to cut the chief artery of labor, without which the lands of fabulous fertility would fall into desuetude, and the multiplied needs of service would go. Yet to retain them in their present condition meant perpetual friction between the upper and nether millstones of society.

The thought of bringing to the South an element of labor imported from abroad was sometimes suggested as a means of relief, and measures looking to that end had been introduced into some of the legislative bodies of the Southern states. But so far from a step like this leading toward solution, it would only result in the aggravation of conditions, for then there would be introduced an additional element of discord and friction. This was the view from one side of a most serious situation.

From the side of the emancipated blacks it was equally as bad, if not worse. The Negro was poor and ignorant, rough, and in his present state had no place in life. He was eager to learn, but there were no facilities for instruction, and the belief was prevalent 
among the whites that increased enlightenment would mean decreased efficiency. He was without training in the new sphere of independence, and without judgment. Some points of sympathetic contact with his former owner existed, but they were not of a character that conduced to general race elevation. They were more of pity than of substantial and enduring helpfulness. Pity is generally a most commendable virtue; but in this instance, as applied to the liberated black race of the South, it tended to contempt and humiliation, and this, in turn, to degeneration.

In brief statement, this was the bi-racial condition in the South at the time now under review. It gave birth to the expressions, "The Negro Question" and "The Race Problem," the very utterance of either of which in almost any circle would awaken prejudice and suggest perplexity which boded no good to the recently emancipated. How were the difficulties which embarrassed the situation to be removed? This was the ominous question of the hour. Its answer lay in the womb of the future. Years must be required to answer it.

Meanwhile a former slave boy, an agency least suggested to any, was being gradually equipped to press the solution to the front. He no more conceived it then, nor even remotely conjectured it, than any other. Providence is full of surprises. A solution equally acceptable to the members of both races and, at the same time, commending the Negro race, would remove much serious misapprehension. While doing this would not entirely remove racial hostility, it would 


\section{LIFE OF BOOKER T. WASHINGTON}

so effectually tone into soberness the tension of public sentiment that an attitude of thoughtful consideration would follow. A new sentiment would have, first of all, to be brought about and so far as then appeared, there was no one to do this. Conciliation must be had before consideration.

As has already been shown, it was not possible, at the time, for a Southern white friend of the colored race to espouse its cause, even had one been so disposed; for had one lifted a voice or raised a finger in behalf of the Negro he would have found public sentiment very much opposed to the step, and would have invited only railing outcries from the seething vehemence then prevalent. At the same time, it would have been thought more impossible for one who had been a slave to do this. But there was coming about a means which would eventually find expression. God hid his power in a young colored man and set him forward to give expression to the solution.

To resume, now, the narrative, Washington was destined to encounter a twofold difficulty of immense proportions. The social, political, and moral conditions of the whites were a most serious barrier, while the poverty, ignorance, and scattered condition of his own people, with no means of intercommunication, was another. Still he firmly believed then, and did to the last, that his people would eventually come to their own by downright merit, a quality that could not fail to recommend itself even to the obdurate. Nor was there wanting at least a partial desire on the part 
of some of the whites to see a change from existing conditions.

In the fall of 1878 , realizing his own scholastic limitations and deficiencies, Washington decided to go to Wayland seminary, at Washington, and prosecute his course farther. While doing this he would obtain an acquaintanceship with a side of the life of his people entirely new to himself; this would give him not only increased facilities of instruction but a wider view of life. The information which he was destined to gather in the national city, aside from his studies, was just as essential as that at Hampton. Conditions were vastly different from those which he had known at the school on the Virginia shore. At Wayland seminary he met many colored youths with plenty of money to spend, no matter whence it came, and they would spend it and pass into oblivion without once being heard of by a great race in distress. They wore fine clothes, and with gloved hands played the rôle of sport, as they drove fine horses along Pennsylvania Avenue. Colored girls were there, who in their anxiety to "shine in society" obtained money in vicious ways, and went the road to ruin. Not that this was generally true of the spirit of that school, but it was sufficient to give to the practical and studious mind of the young man despair of anything hopeful for the race from a quarter like this. No matter whence these boys and girls had come, he had sprung from the commonest walks of the life of his people, knew their distressing needs, their lack of direction, and scenes 
like these did not appeal to his judgment, but they rather saddened his intensely earnest spirit.

But this was not all that he met in the national capital. In Congress were men of his own race who were able to bear themselves with ability in the councils of the nation. They did not have to assume an air of bumptiousness in order to excite attention to an assumed consequence, nor did they have to cringe in suppliance of due recognition-they were simply men of ability among others. These were not without valuable suggestions, while they were a source of inspiration to the younger man, already serious in his impression of the importance of the race becoming that of which it was worthy and capable.

Between the two classes there was a far cry. Washington would accept the lessons from the one, and reject the other. He was greatly inspired and impressed by Senator Bruce of Mississippi, who, though a colored man, disarmed the prejudice of all by the simplicity and naturalness of his manner, and by his courtesy to everyone alike. Such was his bearing that when, later, he retired from the senate, Hon. L. Q. C. Lamar, who afterward was on the Supreme Court bench, took occasion to speak at some length on the merit and ability of his retiring colleague. Senator Lamar was a man of proportions sufficient to accord to the colored senator the merit of his just desert, and sufficiently courageous, even at a sensitive time racially, to defy unworthy sentiment against one because of his color. There was in all this, abounding suggestiveness to the receptive and judicious spirit of a man 
like Washington. There were others of his race in Congress by whose brilliancy and force he was impressed, but by Senator Bruce he was most captivated because of his naturalness and the utter absence of the supercilious spirit.

Up to this time the contact of Washington with members of the white race had been only of an incidental character. His first years on the plantation were spent apart from them, and only slight occasion had since that time been afforded him for touch with them. He had shown unusual timidity in approaching any white person during his career as a laborer, and the bearing in the mansion in which he served at Malden, made him squeamish, for fear that he might incur the disapprobation of Mrs. Ruffner. Although at Hampton he had come into somewhat closer touch with General Armstrong, still he regarded the bearing of this great principal as being due more to his position as a teacher of Negro youth than to genuine and sincere friendliness. His superficial view was due largely to the violence of the $\mathrm{Ku}$ Klux Klan and other agencies, and to the fervid tone of the Southern papers of the period in which the Negro was a special object of denunciation. All this created in him a sense of awe bordering on fright.

Hence his astonishment was the greater when, the close of the year at Washington, he received a formal invitation from the leading white citizens of West Virginia to go before the people of that new state in advocacy of the transfer of its capital from Wheeling to Charleston. For more than a year the 
matter had been agitated, and popular sentiment had at last reached a pitch that made legislative action necessary. That he had arrested the attention of the whites in his undemonstrative work at Malden was now quite plain, but Washington himself had had no idea of it till the receipt of this most courteous invitation. Here was added another element to his future career, and from a quarter most unexpected.

Without hesitation, accepting the invitation, he proceeded at once to West Virginia, and threw himself into the spirited canvass, speaking throughout the state day and night for three months. His calm bearing on the stump, devoid of ostentation, his ready utterance and free, jovial manner, with a quaint humor lurking in his sallies, and, withal, his utmost respect for all opponents, won for him immense popularity. He would never suffer himself to be drawn into warmth of expression, no matter how pert the sallies made, or the flings offered. Without bluster or rant, so characteristic of colored orators of the time, he was so forceful and convincing that the masses heard him gladly, and his speeches became the subject of much favorable comment. It was difficult to decide which class more appreciated his addresses, the whites or the blacks. He received little short of an ovation throughout the entire state. While Charleston won the location of the capital, more than that resulted to Washington from the heated canvass. The young colored orator had demonstrated the capability of his race in excess of any impression hitherto made in that state. He had inserted the wedge of cleavage 
in public sentiment respecting the Negro, at least in West Virginia.

As a result of the campaign, Washington was earnestly solicited-by-members of both-races-to-enter politics. It was urged that he would at once take an advanced position and prove the peer of any of his race then in public life. This solicitation did not fail, for certain reasons, to appeal to him. He had just seen the positions of consequence held by men of his race in the national capital, and the position of the white race in politics seemed secure, while the Negro needed to be represented. Still he saw but little in a political position that would reach and affect the race in its depths and varied needs, and to the welfare of his people he had dedicated his life, so he would not listen to the flatteries of his persuaders.

Washington was not indifferent to the political privileges which he wished to see his people enjoy, but there were other considerations which were of far more fundamental value than political rights. In this view he was nat supported by some of the leaders of his race, but this did not affect his opinion. He felt that for that which would come politically to his people they could well afford to wait, in view of the necessity of other possessions more important. Washington's idea was that the Negro needed economic independence far more than political; he needed more the possession of land and a home, and the education of his children.

Just after the West Virginia campaign, Washington was invited by General Armstrong to deliver the post-graduate address at Hampton at the approaching 


\section{LIFE OF BOOKER T. WASHINGTON}

Commencement. To him the offer of an honor like that was most gratifying. While he had graduated with some distinction from Hampton, he had been the college janitor throughout his collegiate career, and was as much distinguished for his ability to sweep as for his scholastic qualities. He was not in a position, therefore, to expect the distinction. In high appreciation of the honor he set himself to the preparation of an address on "The Force that Wins."

As he went toward Hampton in compliance with the honored invitation, he passed over the same route pursued several years before, and naturally his thought would revert to the difference between his condition then and now. Then he was an ignorant pauper going in quest of a place of which he had heard and the direction of which he had learned from others. Now he was passing over the route under conditions quite different. Then there were railway facilities in the direction of Hampton only in part, now the gaps had been filled, so that he could travel the entire distance by rail. Then he suffered from unavoidable hardships, while now he had ample means of comfort. Then he was utterly unknown, now he was recognized by those who knew him as the foremost young man of his race. In coöperating with self-effort, Providence had wrought a wonderful change.

The address was delivered at Hampton, the congratulations were numerous, and the young orator returned to his home, with plans still unformed for the summer and fall, when he received a letter from General Armstrong offering him a position at Hampton 


\section{HIS LIFE WORK}

with some unusual advantages to do advanced work in the prosecution of his studies. For the time Washington was unwilling to surrender the work so auspiciously begun at Malden, to which point he had returned with a view of enlarging the educational facilities of his people; this would be the easier since he had made so many friends in the canvass of a few months before. He felt sure of aid which had been hitherto unavailable, and the opportunity was favorable for planting a good school at Malden. Yet, while reluctant to give up his cherished project, he felt that he might enlarge his facilities for usefulness by going to Hampton, and therefore accepted the offer made by General Armstrong.

The position assigned to the young man at Hampton was a novel one, and he at first doubted his ability to meet its demands. It was an experiment made by General Armstrong to test the ability of the Indian to learn. More than a hundred young braves had been procured from the western reservations and brought in a body to Hampton. Fresh from the interior reservations, they were wild, and totally ignorant of the ways of civilization. Assigned to a separate building on the grounds of the Institute, Washington was to room in the same building and have complete oversight of them, and, with the aid of assistants, train them first in the rudiments of civilization. Their faces were smileless, their eyes keen, they wore blankets, and a long tuft of hair down their backs. Washington had some misgivings of the submission of the Indian to the discipline of a Negro, but 


\section{LIFE OF BOOKER T. WASHINGTON}

he would combine kindness with becoming firmness, and he soon found that the Indian would yield to these as readily as any other. The long hair had to be clipped, and the blanket exchanged for a civilized garb, again'st both of which the young bucks of the plains at first protested; but finally they were induced to yield. He was encouraged by the progress made by his novel pupils as with the readiness of their response to his orders. If the Indian was a novelty in the school, the surroundings were equally a novelty to the Indians. Regular bathing, certain meal hours, the enforced regulations of study, and, most of all, the immense buildings, were sources of unending wonder to the young men from the wilds. Not one of them could at first speak a word of English, but by degrees they acquired a knowledge of the tongue and gradually came to glide into study along with all others.

After spending a successful year in this novel work, General Armstrong requested Professor Washington to take charge of a large and growing class of indigent students who had found their way to Hampton without means, and who could study only after the work of each day was done. These had to labor during the day to meet expenses, and to study at night. He succeeded in infusing an earnest spirit into this mass of unpromising students, and stirred them into diligence by naming them the "plucky class." $\mathrm{He}$ could the more readily adjust himself to their demands, for he had not long been outside the same class himself. These earnest boys and girls proved to be among the most studious of the school, and to be 
able to go out from the institution with certificates of proficiency from Washington was to each a consuming ambition.

As we now come to the eve of the entrance of Washington on his monumental work at Tuskegee, it is interesting to regard the rapid progress made by him within a few years. The condition of no one ambitious for an education could have been more discouraging than was his. Every possible obstruction was in his way at the outset. If one like him could succeed, none need despair. He met with cool and resistless courage every difficulty that disputed his way, and won. He acquired power in the process of turning every difficulty into an element of success. In the annals of America there is no trophy of democracy that outshines Booker T. Washington. No matter what the odds were against him, he declined to be discouraged. This was the master motive of his life. As we shall have abundant opportunity to see later on, his difficulties grew in corresponding magnitude with his advanced positions. If encouragements came, they were attended by difficulties of corresponding size. While he had encouragement to advance, he had discouragement often sufficient to appall and to check. But he believed that there was a way out of every trouble, and to this thought he steadfastly clung and by it was stimulated till the difficulty finally gave way to his irresistible pluck and downright doggedness and unconquerable persistency. Absolutely nothing could thwart him. He believed in himself as does every man who succeeds. 


\section{LIFE OF BOOKER T. WASHINGTON}

Back of all this was his soul-possessing idea of aiding others, especially of his own race. Lured at first solely by the idea of procuring an education, this gradually succumbed to another dominant thought which was injected into his life, and that was to turn that which was his, as won, to the good of his fellows. Then, too, his judgment was not only cool and clear, but discriminative. Of course this was largely the result of training and experience in his varied ups and downs. He was without impetuosity of decision. He schooled himself to temperamental calmness. While naturally gifted with coolness, he re-enforced this with a growing stock of observation and instruction, and calmly weighed men and affairs. $\mathrm{He}$ was never hasty of utterance. Many times was he subjected to a fierce fire of criticism, and he knew the importance of preserving a golden silence. He knew when to speak and when to keep quiet. Even in his younger years, before he had entered on the herculean task of his life, these elements attracted the attention of those who knew him best. $\mathrm{He}$ philosophically recognized the limitations imposed on him by reason of his position in life, and did not chafe under them, nor resist them, but falling into the current, he watched for every passing advantage, seized it, and turned it to good account. Devoted to the good of his people, he never lost sight of any advantage that would contribute to that end. Many did not agree with his methods, his motives were often questioned, but he held on his way, and when the curtain fell on the scene of his life, his career had vindicated 


\section{HIS LIFE WORK}

the purpose that had dominated him, and in the aggregation of the results it was seen that none other of his time and of his race had approximated the good that he had wrought not only for his people, but for the entire country. 


\section{VIII}

\section{TUSKEGEE}

TEAR the eastern confines of Alabama, located close to the center of the state, is the county of Macon, one of the famous Black Belt region, noted in the days of slavery for its production of cotton. The seat of justice of Macon County is Tuskegee, one of the interior social and wealthy centers for which the South was at one time noted. Like many other points in the South, Tuskegee was the residence of a number of wealthy planters whose plantations lay in the adjacent regions, tilled by numerous black slaves. The homes of these land barons were distinguished by splendor, refinement, all the evidences of affluence, and by the copious hospitality for which the old South was proverbial. In them were hosts of well-dressed colored servants-porters, maids, laundresses, cooks, coachmen, butlers, and hostlers. It was a typical Southern town of the olden days. Within its limits were institutions of learning of high order which lent significance to its culture. Its streets and roadways were lined at long intervals with the architectural beauty and gravity of the old colonial mansions of the rich planters, while its places of business were sufficient to meet the demands of an inland town. 
In the year 1857 Tuskegee was at the height of its social and educational splendor. It was classed as one of the leading interior towns of Alabama, and from it went forth judges, congressmen, educators, and, at a later period, men who won renown on the fields of battle. At the time alluded to, nothing seemed more inevitably perpetual than Negro slavery. There was no other thought in the minds of the people in that tranquil community of wealth. They were undisturbed by the outbursts of oratory in New England and elsewhere, against the institution of domestic slavery, addresses concerning which they would leisurely read, as well as of the proceedings, sometimes of a stormy nature, in Congress. James Buchanan had just taken his seat as the fifteenth elected president of the United States, and in his first annual message to Congress had complacently said, in substance, alluding to the Kansas question, that since the agitation of slavery was now over, the country might return to matters of grave importance. Just after this deliverance from the president, Chief Justice Taney had rendered his famous decision in the Dred Scott case, in which he took occasion to recall, in justification of his action, that of the original builders of the nation: "They [the Negroes] were at that time considered as a subordinate and inferior class who had been subjugated by the dominant race, and had no rights or privileges but such as those who held the power and the government might choose to grant them. They had for more than a century been regarded as beings of an inferior grade, and so far inferior that they 


\section{LIFE OF BOOKER T. WASHINGTON}

had no rights which the white man is bound to respect; and that the negro might justly and lawfully be reduced to slavery for his (the white man's) benefit."

Assurances like these from the highest possible sources calmed into serenity apprehensions that might arise in the minds of any. Evidently all lawful holders of valuable slave property, the most valuable of all Southern assets indeed, were to retain these beings in perpetual servitude, to till their fertile fields and to fill each year their coffers.

In the same year, I857, a slave child was born on a Virginia plantation, of an ignorant black cook, who was destined within the next twenty-five years, to appear on the scene at Tuskegee as the harbinger of a new order induced by the intervention of many changes. The events were to come in an order of logical sequence-a long and bloody war, slave emancipation, political and social disorder, during the prevalence of all which Tuskegee would decline, like every other Southern community. This infant slave was destined to come to relieve confusion by a method all his own. He would accomplish that which was baffling the sagest statesmen and the ripest philosophers of the time, and bring order out of chaos. The emancipation of the slave had induced an entanglement of both races, and this slave boy was to discover the means of relief. It is difficult to find in history a parallel to a condition so anomalous. Yet the means by which all this came about was thoroughly logical.

Of the change wrought at Tuskegee within the quarter century lying between 1857 and 1882 , nothing 
more need be said than that it had come about in a regular but revolutionary order. The abolition of the institution of slavery had resulted in the overturning of the South's industrial system, which reposed on the labor of slaves. The freedom of the slave in his ignorance and poverty had set him adrift, and the whòle situation had resulted in race friction and alienation, to the detriment of both white and black races. Thoughtful men of both longed for a change in the situation. The past was full of darkness and sorrow, and the future was altogether uncertain. " To the dominant white the situation presented a perplexing problem-to the disturbed black man it was an occasion of deep sorrow. The novel situation induced by the sudden emancipation of millions of slaves and by their transformation into citizens, resulted in a change so appalling as to bewilder the wisest. No hint or suggestion of relief came from any quarter. The tension was just such that any suggested means of deliverance from the situation would have been hailed with delight. Grave concern had come to take the place of disappointment and passion. Even the most vehement among the whites had become sobered by the protracted disturbance, the tendency of which was in the direction of that which was worse. On both sides of the race line there were serious concern and profound perplexity.

It was at this juncture that a few colored men, late slaves, made an humble overture to the Alabama legislature for an appropriation of money sufficient to found a school for the training of young colored men 


\section{LIFE OF BOOKER T. WASHINGTON}

and women as teachers and leaders of the race. This suggestion was the only feasible one that occurred to them as the beginning of a course that might bring relief. With but slight confidence in the virtue of the proposed plan, the Alabama legislators felt that for the sake of an experiment the sum of $\$ 2,000$ might be risked from the treasury of the state. Still, only slight faith was had in the success of the proposed undertaking. Nor must the small amount be spent for any other purpose than that of paying teachers. Beyond that restriction and that of naming Tuskegee as the location of the proposed school, the measure did not go. With practical unanimity the step was regarded as one of folly, ridiculous, and a wild-goose chase. However, if by the use of the trifling sum of $\$ 2,000$ invested in Negro brawn and brain, any good could come, they were willing to incur the risk. The nature of the measure itself would seem to place the success of an undertaking like this in jeopardy at the outset. No land was provided, no buildings were bought, or erected, nor any provision made for these necessary concomitants, nor for the slightest equipment of the school. However, if with the little dribble the colored people wished to provide teachers and leaders, they might proceed to do so!

But what could a mass of ignorant, penniless people do with a sum so slight, in the establishment of a school that was expected to produce leaders and teachers from their own ranks to direct their people through a crisis so dire? They had no means of their own, no land, no idea of how to establish a school, and no 
teachers, even if the school were founded. The provision, instead of aiding, only served to embarrass the situation the more. It was not that the Alabama legislators were indifferent to the seriousness of the situation, but they simply had no confidence in either the ability or the capability of the Negro to do anything but to wield the implement of labor. He was deemed as utterly incapable of the acquisition of knowledge beyond the barest rudiments, which opinion was reenforced by the theory that education would spoil him. It would fit him for a sphere in which the Negro could find no place, while it would ruin him as a laborer. A boon to all others, education would prove only a bane to the Negro. The idea of it was hooted at as chimerical, and laughed at as a fool's errand. If the coming generation could be made better tillers of the soil, well enough, but the idea of Negroes attaining to scholarship, and to ability to teach and to lead anybody was preposterous! This was the current conviction at that time.

However, the more thoughtful and serious of the colored race would not give up. They would see what might be done. Influential white citizens of sympathetic temperament were enlisted, most of them only partially; but one, George W. Campbell, of Tuskegee, a merchant, banker, and an original owner of slaves, was seriously sympathetic in behalf of the movement. Plain, direct, matter-of-fact, and intensely practical withal, Mr. Campbell felt that it might be encouraged with some promise of ultimate success. At any rate, an honest venture might disclose a workable plan. In 


\section{LIFE OF BOOKER T. WASHINGTON}

his efforts he was seconded by Lewis Adams, an unusually wise and wide-awake ex-slave. For the opportunity which he had enjoyed, none of his race was wiser, none more sagacious. In the days of his servitude he had acquired skill as a shoemaker, a harnessmaker, and a tinner. These two, a white man and an ex-slave, coöperated initially in the movement.

The legislators had done their work and had gone to their homes, dismissing any further thought of the chimerical dream of a normal and industrial school for Negroes. The seriousness of the undertaking had come to repose on the white man and colored man already named. They began to cast about for a practical beginning. What could possibly be done? No white man would assume to establish a Negro school, and the Negroes in their universal ignorance had no one to propose for the management of the school which existed as yet only in imagination. In truth, there was but little to be managed, when only $\$ 2,000$ was available, and that was so circumscribed by limitation as to make it practicably unavailable. Nothing could have been more farcical than for an ignorant race, utterly pauperized, and without the slightest idea about founding a school of any character, to assume a task like this.

Once enlisted, Mr. Campbell began to correspond with well-known educators and others relative to the possibility of finding a colored man capable of assuming a task so serious within itself, and the more serious because not a cent was available for first establishing 


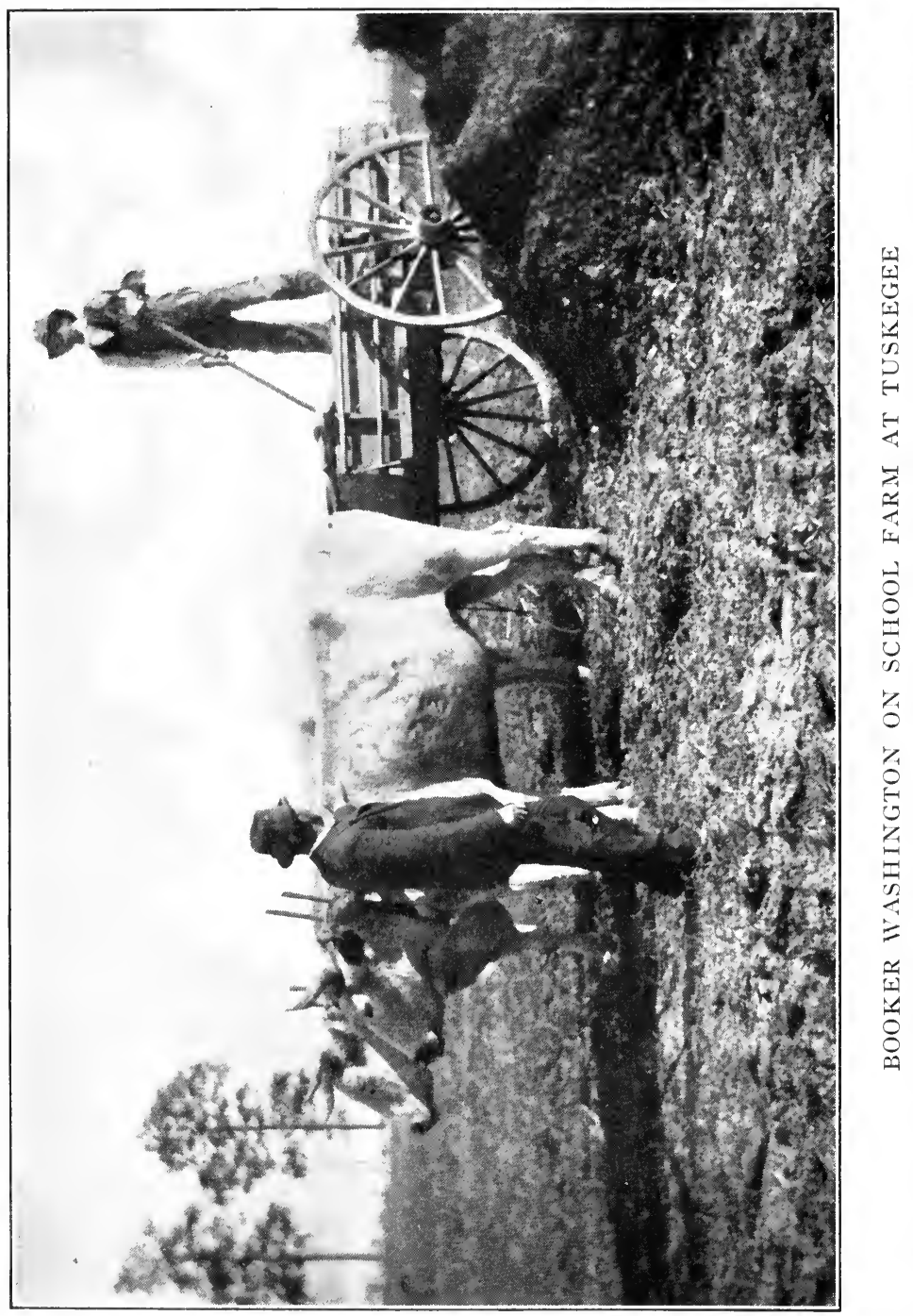



the proposed school. Throughout it seemed a comedy play, if not a roaring farce.

As a result of his correspondence Mr. Campbell came upon the fact that at Hampton, Virginia, there was a colored school devoted to the preparation of teachers for intellectual and industrial education, and he was informed that he might be able to receive some illumination in relief of his perplexity by writing to the Principal of the Hampton school, General Samuel C. Armstrong. This led to an exchange of letters between Mr. Campbell and General Armstrong, the latter stating that there was a young man at HamptonBooker T. Washington-whom he could recommend.

At the time, Washington was absorbed in his night work at Hampton, or in encouraging his "plucky class." General Armstrong had submitted the matter to Professor Washington, under the impression, gathered from the drift of the correspondence, that new buildings with adequate equipments were in readiness for the assumption of control by anyone whom he might recommend. After a time he received a telegram from Mr. Campbell: "Booker T. Washington will suit us-send him on."

The dispatch was received on Sunday evening while General Armstrong was conducting the chapel exercises at Hampton. When the exercises were over, he read the message in the presence of the entire school, and it was greeted with wild applause. Congratulations followed in abundance, and Professor Washington began to prepare to go to Tuskegee to take charge of what he at the time thought was a great 


\section{LIFE OF BOOKER T. WASHINGTON}

school, with ample buildings and adequate equipments.

On reaching Tuskegee in May, I88I, he was not only greatly surprised but profoundly disappointed to find the situation just as it was. What was he to do? $\mathrm{He}$ had been sought, highly recommended, and sent, but he found absolutely nothing with which to begin save the slight appropriation. He was young, being only twenty-four, and had never faced a serious responsibility, was a stranger in a strange land, and without reputation. In addition to this, he was the representative of a race of people against whom there existed much hostile sentiment. They were poor and illiterate, and the few strides they had taken in the life of freedom were mostly mistaken ones. There was much racial hostility and almost universal distrustfulness either of the capability of his people or of their integrity. As a strange young man with an education, he must encounter the strong sentiment against an educated Negro. His condition was little short of being deplorable.

Almost any other would have been paralyzed in spirit by the appalling situation. He could have gone back to Hampton fully vindicated after explanations. Who could blame one for declining to undertake the practically impossible?

After mature deliberation Washington resolved to try out the situation to the utmost. But how was he even to begin? He had no means at hand through which to reach the people in order to solicit patronage, now an unquestioned necessity. For a Southern newspaper at that time to have alluded in any way to a 
prospective Negro school, or to a colored teacher coming from Virginia to establish a school for blacks, no matter for what purpose, would have created a stormy sensation. Even had there been facilities of advertisement, his people could not read. For the same reason, it was folly to think of correspondence by letter. There was nothing left him after his final decision to venture, but to go boldly out among his people in the country, visit them as rapidly as possible in their homes, and solicit what patronage he might. To this course he was absolutely shut up.

After conference with his two friends, George W. Campbell and Lewis Adams, both of whom assured him of their sympathy and the utmost of their support, he entered on his canvass. In making his way into the country he had to avail himself of any means possible to go from place to place. Many times he would tramp considerable distances, again he would be conveyed in a buggy or wagon. He found the condition of the colored people miserable in many ways. The huts in which they dwelt were often but little better than pig-stys, their food was scant and poorly cooked, they lived as they had in the days of slavery, an entire family in a cabin of a single room. Yet in an effort to appear to be living in an advanced condition, not a few had bought on the installment plan cheap but ornamental clocks, though unable to tell the time of day; on the same plan, they had organs, pianos, and other musical instruments, yet none could play; large and profusely gilded Bibles, yet none could read. In the neglect of much else that was valuable, 


\section{LIFE OF BOOKER T. WASHINGTON}

the men could talk politics to the extent of announcing to which party they belonged, yet had not the slightest conception of the significance of the franchise. In short, he realized that there must be an arrest of present conditions along all lines to save the people from degeneration. Hard as was the lot chosen by himself, there was an under joy within it that changed the bitter into sweet.

The incongruous condition of his people was to him grotesquely and pathetically ridiculous. It appealed to one who, "though young in years, was in experience old." One thing was clear, and that was that at the present rate there was no hope for the Negro race. He saw at a glance how rapidly they must decline in public esteem, and gradually sink into degeneration. Many false notions must be expelled and right ones substituted, and the eyes of the people must be lifted toward the ideals of civilization. In order to this, there was to his mind but one course to be pursued, and that was for the race to begin at the bottom principles of life and work as rapidly upward as possible. The utter absence of school-houses in the country was enhanced by the fact that they were useless so long as there were no colored teachers. His people worshiped, for the most part, under brush arbors, and the preaching which was dispensed consisted almost entirely of vociferous outcries by the minister, so-called, who would say next to nothing, relying on his intonations of voice and violent antics to create frantic excitement among his auditors rather than to impart instruction.

Washington was beset before and behind with every 
conceivable difficulty. He soon found that while there were many friendly whites there were many others who seriously doubted the propriety of the venture on which he had entered, thinking it one which would undermine the value of the Negro as an economic factor, the theory being that in proportion to his education would he decline as a contributor to prosperity. There was some cheer in the fact of the toleration of "a risk" in that direction. It implied that they would watch his venture, and be governed accordingly, and this imposed an obligation on himself that burdened his spirit.

The summer of $188 \mathrm{I}$ was over. The canvass of a limited territory had closed, and arrangements had been made to open the industrial institute for colored people in two dilapidated buildings, one a run-down church building and the other a nearby cabin. Thirty students from the town and the adjoining country presented themselves for enrollment, and with these shabby beginnings the school began. Most of the members of the student body were teachers, some of whom had already reached middle age. Their notions of what an education meant were the rudest and crudest possible, some even venturing to suggest that they wished "to push right through," within a period of three or four months at the most, get their diplomas, and hurry back to their schools. All this suggested to the young man the tremendousness of the task that he had assumed.

He firmly announced his double aim in conducting the school,-the construction of character, not pro- 


\section{LIFE OF BOOKER T. WASHINGTON}

fessedly, but positively, and utilization of education. To make these two principles mutually aid and supplement each other was the basis on which he began and which he continued throughout his career. His people had freedom, but they had not yet learned how to apply it to the best use. They were in a wilderness of confusion. That which they mistakenly did, indicated that they would do the right thing if shown. The extravagance in expenditure for useless articles in their homes was not without a favorable side. It showed that these illiterate people were seeking to be worth while, and this course seemed the one most conducive to that end. The fad of adopting long names and middle names was not without suggestion of a commendable ambition which was ill-directed. All this quackery he would replace with that which was solid and substantial.

Distressing as was that side of the situation, there was another equally so. The Negro had till recently been a valuable chattel, but was suddenly transformed into a citizen. Not only was he a valuable asset taken away, but at a time when the country was in ruin from the war. Irritation and pent wrath occasioned by this condition were visited by some on the passive black man. Then the turbulence of the reconstruction period was still a memory of the immediate past. In not a few counties of the Black Belt the blacks outnumbered the whites, sometimes six to one. In a number of the original slave states, the populations, white and black, were about equal, and in perhaps more than one, the blacks outnumbered the whites. The murmur was that 
for more than ten years these people had been free, and they had been years of turbulence. They were still groping in darkness, were still the same mass that they were when they were liberated. The discussion of the Negro as a menace to civilization was common in conversation as well as in the press. Numerous theories obtained as to the ultimate result of this, none of which was favorable to the unfortunate blacks.

What could be done to relieve the situation? In the tension of the times, sweepingly decisive plans were proposed, some the most inhuman possible. The old-time idea of colonization was openly advocated. The slogan, "This is the white man's country," became to some a dominant note that thrilled. A western reservation was suggested, then Mexico, and again Africa. That this did not assume some sort of shape was due to two very practical obstructions, one of which was its cost, and the other, the indispensableness of the Negro as a laborer. A few openly advocated annihilation, but this was ridiculed by the many. Still the fact remained, still the problem pressed.

All these, it will be observed, looked only in a detrimental direction to the Negro. The forces of elevation were only partly and weakly urged-those of education and of patient evangelization. Force and not suasion was the sentiment, not universal, but general.

Nor was this yet all. The short-comings of the Negro were exaggerated by reason of the sensitiveness of the times. Those in search of faults in others are apt to find them. In his ignorance and blunder- 


\section{LIFE OF BOOKER T. WASHINGTON}

ing, his short-sightedness and obtuseness of moral character, all of which were in some part, at least, the fruits of slavery, Negro vice and criminality abounded. This elicited violence on the part of those violently disposed. Whatever the profession of the Negro, he was, on all hands, suspected. Then came the indiscriminate judgment of the Negro. A criminal was taken as an apt representative of the entire race. A crime was charged not only to $a$ Negro, but to the Negro, including the whole of the people.

This is a fair representation of the spirit of the times in the interior of the South when Professor Washington made his advent at Tuskegee. It is now recalled only for the purpose of making visual the enormity of the difficulty confronting the youthful leader in his embryonic venture at this particular time. He saw that without systematic direction, and without clearness of aim and distinctiveness of purpose, nothing could be done.

Perhaps the severest test of the moral poise of character to which Principal Washington was subjected was that by a contingent of his own race who objected to his idea and policy of undertaking to provide a foundation basis of labor for the race, as a fulcrum for race-lifting. His purpose was misapprehended, his views were distorted by not a few. To some it bore the aspect of degradation rather than of elevation. To others, it was interpreted to mean the frank acknowledgment of the inferiority of the colored race, while to others it implied the return to practical servitude. Washington would have his people disregard all 
else than the laying of a race foundation sure and firm, in order that thence they might gradually climb upward, being amply able to take each ascending step of the grade by the firmness of the footing already secured. His conception of a bottom race beginning at the bottom, in the region right about it, was vindicated alike by logic and by history.

The opposite course, that of the race seeking by a single bound to vault to the summit, was against the simplest law of nature and in direct conflict with all racial history. Of this he had known the most lamentable exhibitions. He had seen the shoddy and superficial fellow with a smattering education, decked in the garb of the latest fashion, who found no sphere in which to move because there was none. He had seen the unequipped and the unprepared tumble from his superficial eminence because he had none of the forces to maintain him. He had observed with interest and concern the laudable but mistaken efforts of his people in the far interior, seeking to find the way to respectability by the purchase of showy tinselry and ornamental books and furniture for which they had no earthly use, while the children remained unfed and unclad, and their miserable places of abode were but little better than the stalls of oxen.

Against all this folly he set himself, not captiously nor abusively, but patiently and persuasively, and was willing to go into the trenches of the struggle alongside them in their honest efforts to aspire while he would direct. Misjudged, misinterpreted, and often misquoted, he persevered, and when the end came, he 


\section{LIFE OF BOOKER T. WASHINGTON}

left in many thousands concrete evidences of his work.

True, his resources at the outset were contemptible enough in aspect, but they embodied the germ of a new civilization, the norm of a new race, the hidden power of a people who during fifty years of disadvantage exceeded in progress any other race in history within the same compass of time. Washington was a sincere believer in his people. He loved his race, and transmuted bitterness into respect, and hostility into interest, by that which he demonstrated in the unquestioned capability of the Negro. 


\section{IX}

\section{SUPREME DIFFICULTIES}

W

HILE only a bare outline of the situation in the South at the time that Principal Washington began his life work at Tuskegee has been given, sufficient has been presented to show how colossal was the task that he had assumed. $\mathrm{He}$ would secure a sure footing as he advanced. If he had but little either of substantial means or of encouragement, he would make the most of these, and by mounting them, he would gain a view of the steps next succeeding; and if the process was slow and irksome, it at least had the moral value of accomplishing thus much, which was an advance of that from which he had risen. A heroic philosopher, he met conditions as they came, with calm and unblinking front. His was a singleness of aim, a oneness of purpose, that of raising his people to the height of commanding respectability by the possession of virtues which to reject and despise would condemn the despiser. His material was exceedingly crude, but good-naturedly he would mold it into shape by a process altogether natural, and in the end would make the result vindicate itself.

By every means he was qualified for the task. His was no empty theory; he worked by the hard, stern rules of experience, rules he had already tested. $\mathrm{He}$ 


\section{LIFE OF BOOKER T. WASHINGTON}

himself had been in the deeps, as far down as any. He knew the pathway of emergence. Naturally optimistic, courageous, inventive, resourceful, sympathetic, a race-lover and a race-lifter, he knew every step of the way, and thus endowed, he was divinely appointed to the kingdom for a time like this. $\mathrm{He}$ met force, harsh and frowning as it was, with an ability of achievement that sealed the lips of the gainsayer. He was profuse in deed, rather than in promise.

Gathering his little band of unpromising students within the walls of dilapidated buildings, he would demonstrate first to them the possibility of achievement against odds. At times a stretched umbrella had to protect him against the rain pouring through a decayed roof while he stood book in hand, to instruct and inspire. If at other times the umbrella was necessary to shield him from the leaky roof while he snatched his hasty meal in the tumble-down cabin, he was inspiring his pupils by an example that made heroes and heroines. This spectacle of heroism is worthy of the encomium of any pen, yea, it is worthy of the emulation of any. The demands of the time were rigorously exacting, but he had the pluck to meet them. Had he been other than a struggling Negro, sympathy and support would have flowed to him in confluent currents, but he, and he alone, had to receive the dire predictions of failure and endure the whispered innuendoes that the upshot of the whole thing would be the engenderment of mischief in the heart of dangerous Negroes. Taken all in all, it is impossible to conceive of a situation the endurance of 
which surpasses in severity that which he was compelled to undergo in these opening years at Tuskegee.

$\mathrm{He}$ gave vent to no rash promises of success. He regaled none with rosy dreams. When reviled he reviled not again, but with philosophic fortitude bore all in cheerful silence, and labored on. Out of the depths of his own discouragement he sought to inspire courage in the hearts of his people, and in the midst of bitter environments he was still courteous to all alike. Having but little, he would use that to the utmost. Thwarted in one direction, he would turn, with his wounded spirit disguised, calmly in another. Members of both races were prodigal of advice and suggestion, to all of which he would listen with due respect, and then onward plod his own way, guided by a judgment derived from the exigencies of a trying situation. . The numerous instances of discouragement recorded by him in later years in a jocular strain did not move him the width of a hair from his quiet and settled purpose. When a colored brother undertook to lecture him most seriously in derogation of his policy, by telling him that labor was originally cursed, and that therefore to teach to labor was criminally wrong before the Most High, it only appealed to the humorous side of his nature. When accused of being in collusion with the whites to bring his people back into slavery, because he strenuously enforced the duty of diligent activity, he was willing to wait for the future to bring the answer of vindication. Thus he stood with steadfast footing, and bravely met whatever came, without waver of purpose, or diminution of 


\section{LIFE OF BOOKER T. WASHINGTON}

effort. The young man had an ideal, and he would test it to the fullest.

It is eminently fair, in this connection, that appropriate mention be made of the earliest and most worthy assistant of Professor Washington in the outset of his struggles at Tuskegee-Miss Olivia A. Davidson. With exceptional scholastic advantages, she had had much experience as a teacher and successful manager, and her connection with the school at the outset was most fortunate. The distressing condition of her people in the Black Belt lured her more than anything else to join with Principal Washington in his proposed venture. Tempting offers of remuneration failed to divert her from her purpose to aid in the Tuskegee enterprise, and to her more than to any other was Principal Washington indebted for his success in establishing his renowned school. She brought to her difficult work at Tuskegee a most worthy record not only of scholarship and of experience, but of sympathy for her struggling race to which she was ardently devoted. Then, too, she was a woman of rare judgment and of acute discrimination. A graduate of Hampton, her course was subsequently enlarged by her graduation from the Massachusetts State Normal School at Framingham.

A woman of excellent culture, tact, and taste, she was exactly suited to the demand of the situation at Tuskegee in the beginning. The advent of two strange colored teachers at Tuskegee, one from Virginia, and the other from Ohio, would excite not a little suspicion concerning the effect which they would 
have on the Negro population, but so soon as Principal Washington and his able assistant came to be known, they became popular with the leading people of the town. The admirable judgment and race loyalty of Miss Davidson are illustrated by the fact that during her course of study in New England she positively declined to deny her race identity, even though assured that she could do so because of the lightness of her complexion. She openly said that she was a Negro, was proud of the fact, and wished, as one, to assist her people to make the term "Negro" as honorable as any race name. She bore no small part in framing the original policy of Tuskegee, and in view of that which the school has done for the good of the country at large, she is worthy of the gratitude of all the people, irrespective of race.

Had these two worthy and accomplished people been content with mere text-book drill, nothing would have been easier than to have restricted their efforts to this alone; but together they sought the highest and widest equipment of their people for the serious issues of life, and never wavered in their devotion to the attainment of the greatest good. That which they together sought was to make men and women who would become helpers to the vast and needy multitude.

Hailing almost altogether from interior plantations, the colored youth, who sought the advantages offered at Tuskegee were at first largely indifferent to personal cleanliness, either of their persons or of their clothing. Their food on the plantation had been a uniformity of cornbread and fried bacon, and as 


\section{LIFE OF BOOKER T. WASHINGTON}

for tooth-brushes, most of them had never used them.

Nothing was clearer to these worthy and scrupulous teachers than that to do no more than to develop the minds of these young people would have made them totally unfit for life. A course like this would have educated them away from the practical affairs with which they were most familiar. But what could be done to improve conditions in their shabby quarters? Neither Washington nor his able assistant had means to improve conditions. They fully understood the impossibility of the best results-either mental or moral-from conditions like these, but there was nothing left them but to make the most of that in hand, and keep a close outlook for better things as they would be suggested from time to time.

The vision which haunted Washington was that of a fully-equipped school in which mental and manual effort would go hand in hand, so that ability to cope with life's requirements would be acquired by each pupil. He was the more concerned about this with respect to the first students who came to Tuskegee, because in their artlessness and ignorance they disclosed the fact that they were seekers after education as a means of relief from manual or physical effort. The latter would remind of slavery, the former of freedom and independence. To give mental instruction the first year, was all that could be done, and in doing this the utmost was done that was possible with the character of students on hand. Washington continued to dream, however, of a time in the future when 
his perplexity would be relieved by means of ample facilities for training the head, heart, and hands.

If this ideal was to be realized, land, buildings for shops, recitation rooms, dormitories, laboratories, a library, and all else pertaining to a first-class institution, were necessary. But how were these to be had? At that time he had no one in mind on whom he could rely for so much as a cent. His acquaintanceship was very limited. He could not then name a man or woman in all the country to whom he could go with a proposal for aid. He believed, however, that where a necessity was so urgent, a race so eager to advance, and yet so low in the scale of even the ordinary conditions of real life, a way would be eventually opened, however remote it now seemed. One of Washington's staying qualities was that of faith. He believed in himself, in his fellow-men, and in God. It was Napoleon who said: "All the scholastic scaffolding falls as a ruined edifice before one single word -faith."

Fortunately for Washington at this time, land in the South was-very cheap." It went begging in every market. The collapse of slavery had thrown on the market millions of valuable acres that could be had at amazingly low prices. While he had not a dime to invest in land, he could create means by his own exertions, and he was on the alert for any opportunity that might come his way. Investigation brought to his knowledge the fact that lying just outside Tuskegee and running up to its limits, was an abandoned plantation of five hundred acres on which were the ruins of 


\section{LIFE OF BOOKER T. WASHINGTON}

an old-time mansion that had been burned. The original dining-room, a stable, and a hen-house still remained. The land was on the market for five hundred dollars. It was not fertile, yet it was good, and by methods of reclamation and fertilization could be made very productive. While the cost was quite low at that figure, it was high to one who had no money. The combined assets of both Washington and his able assistant were not so much as one-tenth of the proposed amount. However the terms were made easy by the offer of the property for one-half cash, and the balance within twelve months. By making this arrangement, they might occupy the property at once. Washington had had his eye on this tract for some time, and was willing to accept the terms offered, if only a little while could be allowed him to see what could be done. He at once wrote to the treasurer of the Hampton school to know if the amount of two hundred and fifty dollars could be lent him. General Marshall, the treasurer, promptly replied that of course he could not use the funds of the school for such a purpose, but that he would himself lend the proposed amount on the assumption of the responsibility of the loan by Washington.

The kind offer was accepted, and without delay the new owners took possession. The buildings were in a dilapidated condition, not having been used for a number of years, but, practical to the bottom, the plucky Principal began to repair them for use as classrooms-the dining-room, the kitchen, the stall, and the hen-house. Every student was set to work at 
the expiration of school hours, the Principal leading in the labor. This did not pleasantly impress the country school-teachers-the idea of manual serviceand some of them protested that they had come to college, and not to labor in repairing old houses. But when they saw the vim with which the Principal himself went at it, in sheer shame they followed. The houses were duly repaired in the most economical way possible, and gotten into shape for classrooms.

This was no sooner done than Washington went to work to clear land for a crop to be planted during the ensuing spring. Here again the teachers objected, but Washington had thrown off his coat, and gone to work with such vigor that they forgot their mistaken dignity and importance, and followed. The uplands fast assumed an aspect of activity. The old houses reclaimed gave to the situation a new look of life, while the cleared surroundings suggested progress. The fresh movements on the hill stirred the attention of the town, and the locality was visited by not a few to see the wonderful transformation that had taken place. Suppressed criticism came to an end in the town, and with prompt interest the people began to applaud where before they had objected to the location of a "darkey school" in their midst. This was a matter of growing delight to Washington, who well understood that while most of the whites were friendly toward the project, there were others who had misgivings, and were only waiting for something unfavorable to occur so that they might be able to say, "I told you so." Now that the opposite was taking 


\section{LIFE OF BOOKER T. WASHINGTON}

place, the sentiment of the community was in a friendly direction. Success always wins applause, and effectually seals the lips of opposition. With keenness of vision Washington saw this, and more, he saw that he was going to win the favor of the community, on which his venture in establishing a successful school so much depended. Without the friendship of the whites, he knew that success was impossible. Private opinion is weak, but public sentiment is well-nigh omnipotent.

That sentiment was practically demonstrated when Miss Davidson began to canvass the town for aid with which to meet the first note. Every white friend gave something, and the gift was accompanied with words of assurance and of encouragement. This same indefatigable assistant held festivals, suppers, and divers entertainments, to which the whites contributed, but most of their gifts were in the way of direct donations. The news of the success thus far attained spread through the colored population far and wide, a thrill was created everywhere, the whites were talking of the wonderful young colored man and his pluck and progress, and students came in increased numbers. Negroes took fresh courage, breathed more freely, and were profuse in their varied contributions to the advancing cause. A chord had been struck that awoke new energy. The quiet demonstrations on that upland outside Tuskegee set people to thinking, and light came where before there was darkness.

The scene was pathetic in many of its aspects. Every colored man and woman was eager to aid. 
When unable to give money, they would bring as offerings a division of what they called "plantation truck"-beans, peas, sugar cane, molasses, bedquilts, ginger cakes, fresh meat-anything that could be turned into money. One donation Washington long afterward recalled, and always with emotion. An old, ignorant colored woman, in garments worn and faded, but clean, sought her way to the Principal's presence with a bandana handkerchief in her hand. With upraised eyes, filmed by age and hard service, she said: "Mr. Washin'ton, God knows I don spent de bes' days of mer life in slav'ry. I's ig'rant and po, an' all dat, but I knows what you an' Miss Dav'son a'tryin' ter do fer de collud race, an' whiles I ain't got no money to gin yer, I don fotch dese six eggs what I's been savin', an' I wants yer to put dese eggs inter de edication of dese here boys and girls. I's too old merself ter git any good out'n it, but I kin help a leetle."

The Christmas holidays came, affording a new chapter to Washington's observation of the needs of his people. An army of them from plantations near and far, poured into the town, where in masses they floated aimlessly along the streets, many in rags, and the few who had small sums of money investing in gewgaws, candy, snuff, tobacco, and liquor. Days of pauper jollity were indulged in, and it was next to impossible to employ any of them in any labor, for it was "Chrismus times," and labor was therefore not to be thought of. Not till New Year's Day came, was work in order. But to the teachers, ambitious for the 


\section{LIFE OF BOOKER T. WASHINGTON}

progress of the race, the scenes of drunkenness of both sexes, were most shocking and discouraging. Fireworks, firearms, and razors, all freely used by the intoxicated Negroes, resulted in numerous casualties, and a harvest of petty lawsuits was a logical aftermath of the Christmas. Here was suggestive work for the missionary teacher.

During the winter months of the first session, the hours outside of school were devoted to the preparation of the newly-cleared land for the approaching crop. As plans developed, they would, in turn, create others. Each successful development was closely followed up, and with increasing encouragement conditions were improving. While Washington was making Tuskegee, Tuskegee was making Washington. All successful action is reaction. "Nothing succeeds like success." By dint of unflagging effort and rigid conservation the two hundred and fifty dollars lent by General Marshall was repaid within three months, and the entire debt of five hundred dollars was wiped out within five months-seven months in advance of maturity. To the efforts of Miss Davidson, afterward Mrs. Washington, the cancellation of these debts was mainly due. Together the two teachers planned, and the assistant executed.

The school was now in possession of valuable property, in a location destined to become one of the most noted on the continent. Both races were cheered in so far as they were in sufficient touch with that which had been done, and confidence grew. Other lands were later bought, till the tract after a number of 
years was increased to more than 2,200 acres. An old blind horse was given Washington with which to cultivate his land, but after the payment for the whole had been made, there were no means with which to buy implements; but someone gave him an old hoe, and with this implement and the old blind horse he made his first crop. Every pupil had to labor, or leave, and the rule thus early adopted served as guide to that which all other future applicants for admission into the school were to expect. It served to overset many false notions entertained by his people, but this was what he wished. No one surpassed him in the desire to see his people come into the possession of wealth and learning, but the road to these lay not along the surface of bare assumption. It must be substantially and fundamentally buttressed and ballasted. No man of his race saw this with equal perception at that time. Any other method was that of shoddiness and hollowness. In the face of protest, and breasting opposition, he would proceed to the end. Tuskegee and its achievements tell the story. While the students were laboring at odd hours, they were meeting their current expenses, but this was not all-they were learning the art of doing something that was worth while. This was, and still is, the Tuskegee idea. He taught the honorableness of labor as the highway to independence. The idea is a capital one for any and all to grasp.

The fact must not be overlooked that to Booker T. Washington, the ex-slave, belongs the distinction of establishing the first agricultural college in the South. 


\section{LIFE OF BOOKER T. WASHINGTON}

Its principles were first demonstrated by him. Long in advance of the now noted schools of that character, one of the chief features of later educational methods, he demonstrated on the barren soils of the uplands lying outside Tuskegee how lands can be reclaimed and brought to such a degree of productiveness as to be made valuable. Now, in each state, there is a great agricultural school doing just those things which Washington had done many years before their establishment, and done them as a necessity to a race groping through the gloom for a means of relief. The chief difference between the original school founded by Washington and those later, established in the states is that the students actually labor at Tuskegee, and learn by labor, whereas in the great state schools the work done is mostly in "experimentation." With Washington it was all along lines of experience rather than of experiment.

Financially straitened, nothing was wasted at Tuskegee. Every scrap of everything could be turned to some useful end. The first aim was to produce supplies for the school, but in doing this much else was accomplished. Washington's economical management had already begun to arrest serious attention. He was not only lifting a race out of the mire, he was setting the pace of the redemption of the entire South under the new order to which it was brought as a result of the Civil War. He published no bulletins, advertised no methods, offered no suggestions through the public prints to others. He simply did things! Nor was he seeking to do anything great, he was not 


\section{SUPREME DIFFICULTIES}

even aware that he was doing great things. He was absorbed in the idea of getting his people fairly afoot that they might stand erect and gain a place in American life through merit. Simply and without demonstration he wrought to the benefit of both races in all that he achieved. 


\section{$\mathrm{X}$}

\section{CULTIVATION OF CORDIAL RELATIONS}

TJ HATEVER be the underlying purpose or motive of those who have seen fit to subject Booker $\mathrm{T}$. Washington to criticism and animadversion, the great fact of his successful career is now a matter of history. In trailing the successive steps of his life even up to this time, it seems impossible not to commend that which was done. He was not a noisy man, he was free from ostentation, sought no special methods to bring himself into notice, and when he spoke, whether to his own race or to the whites, he was listened to with profound interest, because he spoke words of wisdom that none could gainsay. All heard him gladly, and only when his language was subjected to microscopic sharp-sightedness and tortured into meaning other than that which he sought to convey, was there ever a question raised. A few times, but only a few, were his utterances challenged. He spoke both South and North, before all classes of people, spoke openly on all subjects, often trenching on grounds the most sensitive where there were ears eager to detect the slightest insincerity to the people of the entire nation; but never was anyone able to force into his lips, even by the most tortuous misinterpretation, anything unbecoming. Speaking 
freely on so many occasions when he might have slipped into unbecoming speech, it is amazing that he did not at times fall into erroneous diction, but no such instance is to be found.

The reason of this lies in the fact that as a man of sincerity he always spoke the truth. While it may have been, at times, distasteful to some, that was no fault of his, if fault there was. The truth, and not Washington, was responsible for itself. Whatever else may be susceptible to answer, a fact never is. It shines by its own light. If he won the confidence of the white race, he did it with honest speech and an horrest-ine Tie condoned nothing: He was not-a mendicant at the feet of offenders. He was careful, and therein lay his wisdom.

The policy pursued by Principal Washington in studiously seeking to maintain cordial relations with the white race evoked not a little adverse criticism, especially from members of his own race. To this criticism there may be given two answers, one of which is that the result is in vindication of his policy. He overcame existing difficulties, and gave to the colored people a propulsion forward far in excess of anything done by any other of the race. Complaint and criticism may be cheap, while that which he accomplished was most difficult of performance. The complaint lodged against Washington that he fawned and cringed at the feet of the white race in order to obtain financial aid in the prosecution of his work, seems strained, both because of the character of the contributors and the occasion of the gifts. The lib- 


\section{LIFE OF BOOKER T. WASHINGTON}

eral donors to Tuskegee were not of the type of men and women who could be wheedled or cajoled into the gift of large sums of money, nor, again, would the donations be made by them to a cause that did not commend itself by undoubted merit. The reflection is thus really diverted from Washington to the liberal contributors to the work at Tuskegee. In addition, the critics do Washington much unintentional honor in assuming that by the exercise of a magical force he could extort these liberal sums from the most cautious of givers.

If the basis of the adverse criticism and complaint be that by compromise, adulation, or fawning Washington was content to disregard the claims of a great and needy race in the promotion of his personal ambition as the founder of Tuskegee, then we have a mere theory contradicted by an undeniable fact. That Washington did succeed in establishing a great college at Tuskegee the effects of which are immense to his race, is beyond dispute. That he not only established the school, but that it is a standard of race elevation is beyond denial. That in accomplishing this, he at the same time wrought a marvelous change in race relationship is unquestioned. That any other course than that adopted would have fallen short of these results, seems clear. That which was actually achieved phenomenally, and a theoretical complaint, are thus set over against each other.

Booker T. Washington was sometimes severely arraigned for not more openly espousing the cause of his people in the South, with respect to much from 
which they suffered socially, politically, and otherwise. The charge, sometimes implied, and again pro nounced, is that because of the position in public confidence attained by him, loyalty on his part demanded that he be heard in a more emphatic way than he was, and that his silence was due to sinister motives of undue if not treacherous deference to the white race. That this is as utterly void of foundation in fact as that already challenged can be clearly shown.

That injustice is done the colored race is a fact lamentably true, and a matter of common knowledge. That this injustice is often imposed for no other reason than that of race aversion, is also a fact. That, politically, this injustice is manifested in the indiscriminate disfranchisement of the blacks, without respect to merit, is also true. That, though sought to be ingeniously disguised in ambiguous phraseology and vague terminology, the fact remains of the existence of taxation without representation, and more besides which is in utter disregard of the constitution, is a fact that cannot be denied. That injustice and forceful cruelty are officially unseen in instances not a few, is beyond denial. None recognize these conditions more promptly than do thousands of the best white representatives in the states of the South, and in tones not to be mistaken, they have inveighed against them; and while these conditions are slackening in their virulence, it is a reflection on American civilization that they exist at all, and the more so that they should have had a sway so wanton in the past; but the condition is here, and must be met not as a theory but as a fact. 


\section{LIFE OF BOOKER T. WASHINGTON}

The problem created by a total disregard of the sanctity of official oath and by wanton murder under the sham guise of chivalry, and the entertainment of antipathy for a reason no higher than that of the pigment of complexion, is one far in excess of an attempted shift of responsibility by dubbing the difficulty a "race problem." If there be a race problem the Negro is not responsible for it, for from the outset his position has been of enforced passivity and victimization which must ultimately appeal to a higher than human tribunal, and which must just as ultimately result in retribution; but up to this time this appeal seems to have been of slight avail. Eminent white men have stood bravely on the floors of constitutional conventions in solemn protest of these wrongs, and have sought to stay the drastic framing of fundamental law by the wholesale and indiscriminate adoption of such absurd provisions as "grandfather clauses," but have failed. Men like these could do so with immunity, but a colored man, no matter who he be, could not. It boots absolutely nothing to say that a procedure like this is unjust and should not be, and that is precisely what was said by fair and fearless men, but all the same, the constitutions were adopted. That an august court of the nation, presided over by an ex-Confederate officer, is, in the exercise of sheer justice, squaring enactments like the ones alluded to in the constitution, is a matter of some relief, but that is only recent.

Denounce the whole-system, if one may, it is nevertheless the will of the majority, and that is the genius 
of democracy. The present writer bows with servility to no sentiment when he expresses the conviction, as he has frequently done, that the line of the right of enfranchisement should not be one of race or color, but one of character. Civilized progress can proceed on no other basis. It is an utterly indefensible procedure to turn away a man of culture and of education, one of good repute and of property, because his face is black or yellow, while an ignorant, unworthy, and incompetent man is permitted to vote because his face happens to be white. To make reply to this that the one is a white man and the other a Negro, is childish aversion too petty to be seriously answered.

Dr. Washington was in a position to do many things, and do them well, for the benefit of both races, but he was not in a position to do everything that needed to be done, nor was any other of either race. He pushed his way to great success and nobly achieved by many successive steps against odds the fiercest. Had he even sought to comply with the implied requirements of his critics respecting the political conditions of his people in the South, that which he was doing would have ignobly failed. The vials of wrath would have been unstopped, and Booker T. Washington would have been obliterated, and Tuskegee would not be. If there be a commendation of his wisdom for any one thing more than for another, it is that he abstained from giving utterance to the things impliedly demanded by his opponents.

The case would have been vastly different had he 


\section{LIFE OF BOOKER T. WASHINGTON}

openly and avowedly endorsed all this procedure. Then the charge of disloyalty might have been laid at his doorsteps. Then might he have been charged with treachery. But none of these things he did. There never came a juncture when he did not do all that was possible. To many things he had to submit in silence because at the time silence was golden. $\mathrm{He}$ was on the ground, was a Southern man, knew Southern sentiment from close observation and study, was a profound student of the most minute of current affairs, loved his race, as his career shows, and deduced his conclusions as the man of wisdom that he was.

That he was not indifferent to certain junctures which here and there arose was illustrated by his conduct when into the constitution of Alabama, the state of his adoption, there was incorporated the "grandfather clause" which many of the ablest elements of the convention resisted, and afterward, in a canvass of the state, sought to defeat, Washington said that the high standard of citizenship erected for the attainment of the Negro should incite him to fresher endeavor to attain to it, and should not occasion undue discouragement. This was far from servile acquiescence in the measure, and far removed from treachery. He knew the situation, and would not sacrifice the possibility of doing great good in many ways, by unwisely and even uselessly inveighing against the impossible. $\mathrm{He}$ was too wise a man for that.

Yet in total disregard of all the conditions involved, Washington was made a target of unjustifiable criticism because he did not unwisely pronounce himself 
apenly against these things which could have resulted not only in failure of attempt, but which would have eventuated in undoing his superior work. There are some reformations and corrections of abuses for which the world will have to wait. There are lagging conditions which need to be brought up abreast of those now in advance. The condition already described is one of them. To seek to pluck the fruit before it is ripe is to do no one good. By his reserved silence on some things, Booker T. Washington was neither cowardly nor sycophantic, but he was wise and levelheaded.

Take the matter of lynching. If he had denounced it as a recrudescence of savagery, he would have been correct. Had he designated it as murder, he would have done no more than to give expression to that which is contained in the statutes of the codes of both human and divine origin, but it would possibly have cost him his life. He kept a faithful record of the number and character of the outbreaks of violence called lynchings, and at the end of every year would publish them to the world, thus educating public sentiment. It may be claimed that this was a cold procedure, but what more could he do? There was no possible chance of activity or of interference on his part at the time of the commission of these crimes.

So, throughout his career, from the outset to the close, Dr. Washington sought to preserve the best possible relations between the two races living in close neighborly touch, and so taught his people. To him it was a study of the best and most effectual means of doing 


\section{LIFE OF BOOKER T. WASHINGTON}

this. More than once the effort was made to show that he sold the rights and principles of his people for a mess of pottage, when, in truth, all his life lay in the other direction. He never lost an opportunity to urge a plea in their behalf, nor was there ever cessation of effort to improve their condition. Had he adopted the policy urged by those who could so easily criticise, and who insisted that he should do so in virtue of his opportunity, his career would have ended, and that which the race so munificently reaped in consequence of his life, would have been lost. The instance was never known of his being before white audiences when he did not present with telling effect the strongest pleas in behalf of his people. This was sometimes done good-humoredly and with not a little sly irony, but it would prevail when other methods would fail. Had he, instead, been violent, or even offensive, he would have cut short his career, obliterated his influence, and undone that already achieved. His method of emphasizing the prevailing disparagement and inequality of advantage between the two races, was illustrated in an address before a crowded house, composed of members of both races, in Atlanta, several years before his death.

The largest theater in the city had been procured, and both races were interested in his visit, which was extensively advertised. In the course of his remarks on that occasion, he alluded to the struggles and disadvantages of his people, in the race for education. Taking up the report of the superintendent of education of Georgio, he quoted the figures of the amount 
appropriated to the industrial education of the whites, and in contrast read out the amount given to the colored schools, an amount much less. With a characteristic smile he laid the copy of the report down and naively said that he knew his race was rapidly increasing in importance, but did not before know that it had so distanced the white race that it required so much more to sustain the white schools than the colored ones! The bit of irony was so keen and the insinuation so clever that it evoked a roar of laughter and round after round of applause in which both races equally joined. It amused while it cut like a rapier, and had a most telling effect. That hit of genuine wit and of sound wisdom was widely quoted and became an effective agent of good.

He surrendered nothing, gave up no conviction, but was ever studious of ways and means for the promotion of the interests of his people. $\mathrm{He}$ was his own counselor as to huw this should be done. That he may at times have erred, is admitted. It would have been extraordinary had he not, but when the multiplicity of situations into which he was brought is understood, and the aggregate of the results is had, his errors appear negligible in contrast with his extraordinary success. Like the lithe sapling of his own Southern forests, he bent to the storm while it raged, and when it was spent, he was still standing upright, while stubborn trunks, in attempting to withstand its fury, fell. By methods of his own devisement he was constantly injecting important lessons into the situation. His people, from the beginning at Tuskegee, 


\section{LIFE OF BOOKER T. WASHINGTON}

yes, as far back as Hampton, were the supreme concern of his life. He often asserted before white audiences that he was proud of being a Negro, and he besought his people to cultivate race loyalty and pride, not vaingloriousness, and to make the race, though now backward and young, one of which every member could be proud. By means like these he commended his people to the other race, disarmed suspicion and criticism, and won his way to the esteem of the best of the white race. He taught the interdependence of the two peoples living in immediate contact, and that the merits or demerits of the one would react on the other.

Illustrations of the effect of a policy like this were abundant, even, in the beginning of the history of Tuskegee Institute. As intensity of interest increased, the young blacks continued to come to Tuskegee, so that it was evident that a large new building was necessary-the first to be erected. As before, no visible means were at his command, not a cent, and there was no substantial prospect of obtaining the necessary quarters. However the new building became a topic of general conversation, not only among the colored people, but among the whites as well, and the discussion made it popular. The cramped quarters and meager means of instruction at his command begat sympathy in pace with the growth of public interest. The necessity had become extreme, and much to his surprise, he was visited by a prominent white citizen who owned a mill some miles away, who proposed to the heroic teacher that he would haul all the 
lumber needed for the new building, place it on the ground, and give him his own time in which to pay for it. While the Principal expressed his gratitude for an offer so generous, he frankly told the mill man that he had no means at command, and no prospect of any, and doubted the wisdom of assuming a risk so great. But the mill owner insisted on doing it, and within a few days the lumber was stacked on the ground.

This meant a revival of the suspended interest on the part of the collectors and solicitors of the school. Dr. Washington and his able assistant, Miss Davidson, at once began a campaign of activity to raise the required amount. A public meeting of the colored people was held in behalf of the movement, to which a lively impulse was given by a Negro laborer from the country, who happened to be present; when the appeal was made he arose and contributed two large hogs to aid in the erection of the proposed building, and in illiterate eloquence, pleaded with his people to unite in sacrifice and devotion for the successful erection of the first building. The effect was electrical and the result most beneficial to the Negroes residing in that region. This incident is mentioned in order to indicate the trifling means at the command of Washington at a critical juncture of the school, and to show the influence which he was acquiring over his people.

Little by little money was collected and husbanded by Dr. Washington and his assistant, and the walls of the new building began to rise. It is due to the liberal 


\section{LIFE OF BOOKER T. WASHINGTON}

gifts of Mr. A. H. Porter, of Brooklyn, New York, that requisite funds were made available for the completion of this much-needed edifice. In recognition of the timely benefaction, the building which still stands as a monument to his liberality, bears the name of Porter Hall.

The straits to which Washington was frequently subjected were illustrated in connection with the erection of this first building. His people had an unenviable reputation of incurring debts with a disposition to ignore them. Washington found this to be one of the chief sources of the existing troubles between the races. He resolved by a course of promptness in meeting his obligations to demonstrate to the whites how honest a Negro may be, and thus set an example worthy of emulation by his own people. It so happened that a note for $\$ 400$ was due on a given day, and when it was made, there was every indication of his ability to meet it. The day preceding that on which the note was to be met, came, and Washington had not a cent. To the young man it was an occasion of agony. Not only would his reputation be involved by his failure to meet his promise, but his example to his people would vanish. The night before the day of the maturity of the note was one of sleeplessness. Morning came, and there was no prospect of his ability to take up the note. The mail from the east reached the institute at ten in the morning, and in the mass of letters received was one from his indefatigable assistant, Miss Davidson, containing a check for just $\$ 400$ ! More than once in his heroic 
struggles were his faith and courage thus signally rewarded.

In the erection of this new building Washington continued to put into execution his well-defined plan of accomplishing a double result by having the students perform the labor. By building this hall they would be able to meet their personal expenses while erecting the structure which they so much needed. The reluctance of some of the colored teachers from the country to engage in manual service, was the more pronounced because they had long ago divorced themselves from such in the rural regions whence they came and had betaken themselves to the dignified pursuit of teaching. To have it understood at home that a young colored teacher had engaged them in manual labor, under the guise of a college course, was more than had been bargained for. But Washington had tact in demonstrating the wisdom of his policy without much ado, and the work went on. Besides the results already named, this course on the part of Washington had the direct effect of disabusing the minds of the whites of the superficiality and artificiality of Negro education. He banished prejudice while developing the minds and characters of his people. 


\section{XI \\ THE INTEREST DEEPENS}

GENERAL survey of the situation in the
South at this period will serve to show the
growing success of Booker $T$. Washington in his novel undertaking, under conditions so embarrassing. By the advent of 1882 , a lull had come in the disorder which had so long reigned in the states of the South. In recognition of the now clearly inevitable, the people had begun to discuss the matter of "accepting the situation," which was only another way of saying that they would set themselves to the work of adjustment to new conditions. A new generation was coming to manhood and to the assumption of the responsibility of public affairs, and the disposition to face things squarely was rapidly obtaining. The idea of seeking to bring the immigrant from southern Europe as a laborer was disappearing, and the black man was coming to be recognized as the only one who was adapted to Southern sentiment and to the tillage of Southern soils.

In some instances colored men were beginning to demonstrate their force by the purchase of land and by successful tillage. The colored man was fast gaining self-reliance. The former slave was not only buy- 


\section{THE INTEREST DEEPENS}

ing land on terms satisfactory both to himself and the original owner, but he was building his homes, stocking his farms, establishing his churches and schools, and tilling the land with increasing intelligence. A few educated colored ministers began to appear here and there, in place of the noisy and frantic class whose emotionalism had too long prevailed as a dominant feature of worship, while Tuskegee, as a lighthouse in a dark and stormy sea, lent increasing relief to the scene.

Pelitical agitation was still rampant, there had come on the scene a new class of politicians. The Southern politician prior to the war had usually been of the highest type of society, a gentleman of leisure, to whom politics was somewhat of a diversion in the humdrum of life, but nevertheless, from pride if from no higher motive, an efficient officer. That class, once the wealthiest, was now more concerned about a livelihood and the rehabilitation of the country, while the man of lesser note and of much less force, had come to the front as a seeker of political honor. He was generally intent on popularity, no matter at what cost, and while worthy men were still retained as representatives of the people, those of the secondary class predominated. Here was a turning-point in the political dominance of the South in the councils of the nation.

This lesser class found an apt slogan in the race question, and it was resounded from every quarter, to the detriment of the Negro. He was the usual text and topic of the ordinary stump orator. The topic was 


\section{LIFE OF BOOKER T. WASHINGTON}

a superficial one and therefore well adapted to his mentality, hence he used it with not a little vociferation. It was through this means that not a few cheap men found their way into position, some coming to occupy the highest places. Nor is the end yet with some of that class.

Out of the conditions of that period grew a situation most lamentable. The prevailing sentiment favored nullifying the vote of the Negro, by any means suggested, and thus it was popular, in making the returns of a given election, to count the Negro out. The enfranchisement of the ignorant blacks was an undoubted political blunder, fully as detrimental to the colored race as to the white, till the colored man could come to know the significance of the ballot. Yet the wholesale demoralization of young white men who prided themselves on stealing votes and stuffing ballot-boxes, brought results from which the South is still suffering. If there was no logical justification in the vote being placed in incompetent hands, equally there was none in the wholesale demoralization then overlooked and indirectly encouraged.

These conditions are recalled to keep within sight of the situation at that time. These facts, however unpleasant now in their retrospection, represent the strenuous times in the South at that period.

From these facts may be seen the difficulty encountered by a young man of the despised race who, while not openly resisting this condition, was seeking to avert the results, so far as he might, from his own disadvantaged people. One of the worst features 
was the example set by the dominant race. The colored man, accused of being a servile imitator, unfortunately imitated the worst examples quite as much as the best. To turn their eyes away from scenes like these was the task of the young colored reformer at Tuskegee. To bring cheer in the gloom of despondency, is not easy for any man, and especially formidable was it to a young Negro. Yet, in spite of the worst conditions, he kept heart and labored unceasingly on. Had it been possible at a period like this for some towering white leader to rise, and with conciliatory spirit and by the pointing of the unerring finger toward the right, direct both races to different courses, the situation in the South to-day would be much improved. To say that it was impossible, by any means, to bring about a change for the better, was concretely answered at Tuskegee.

Amid all these conditions, Washington acted with consummate wisdom and extraordinary foresight. At this distance he glitters like a star in the darkness of that time. No matter what took place, he stood with the steadfastness of a Roman sentinel, and continued his fundamental work for his race. He drilled a pioneer army which would one day be able to demonstrate to the world the capability of his people and demonstrate it by actual deed. To him this was infinitely better than to go on the stump and with ravings and pleadings uselessly spend his force by word of mouth. An attempt of that kind would have fallen on leaden ears and enraged sentiment. Discounted as he may have been at the time by some, 


\section{LIFE OF BOOKER T. WASHINGTON}

his wisdom stands vindicated through the vista of years.

No thoughtful man will say, at this distant day, that this young teacher, trainer, leader, and reformer was not wiser than his generation. No one will now assert that he did not with prophetic and philosophic ken recognize that actual worth would stand appraised, when duly demonstrated by his people, while theory would take to itself a thousand wings and fly away. Who does not recognize the wisdom that he displayed when he insisted that merit would force its own recognition and appreciation, though it be wrapped in a dark skin? Now that the questions of more than three decades ago can be approached fairly free from partisan bias, historic appraisal may be awarded the conspicuous actors in that disturbed drama. Now that Booker $\mathrm{T}$. Washington has wrought and gone, and the tomb seals in silence his tongue, and his spirit of conciliation has passed, let the truth in its fullness be spoken without reservation, and in no uncertain way.

Returning to his cherished project at Tuskegee, we follow for the time the successive steps of its development. He enters on his second year. He is yet generally unknown save to a few friends here and there about the North to whom Miss Davidson has been able so to present the situation at the South and especially at Tuskegee, as to enlist slight sympathy. Weary and footsore she had tramped the streets of different cities, told the story of struggle and sacrifice both of the builders of the school and of those who came to learn, and succeeded now and then in 
procuring a small amount to go at once into the work. The uncouth boys and girls, together with those of more mature years, continued to go to Tuskegee from the plantations, increasing all along the embarrassment of the founder, and thus the struggle went on.

During the second year of the school there was apparent one fact which gave great encouragement to the Principal, and that was the growing loyalty of these rude students to the cause which could hardly as yet be called a school. There was a recognition of their identity with the school. It had now become their school. The labor expended by them in making it had enlisted their interest, and had the moral effect of identifying each boy and girl, no matter how crude at first, with every interest there fostered. Not the slightest abuse of the property, not even defacement of the rude walls, was tolerated by these black youths who found pleasure in alluding to " our buildings" and "our school." Loyalty to the location was already budding, much to the gratification of the young Principal. With acute observation he noted the germination of sentiment like this, and took fresh courage.

The first crop gathered from the soil adjacent to the premises was not large, but it was exceedingly helpful in the replenishment of the food supplies, while the moral worth of the labor to the pupils was of even more profit. Washington was not slow to learn that in the latitude of Tuskegee, vegetables of some kind would grow any month in the year, and having abundant land he would turn it to profitable 


\section{LIFE OF BOOKER T. WASHINGTON}

account. While he was making men and women of the rough material which came to him from the plantations, he was also making sturdy character by training them in the practical arts. In this training lay the redemption of his people.

On the part of Washington there was a homely insistence on industrial expansion. On the land bought was an abundance of brick clay, and he undertook the manufacture of bricks, though ignorant of the art. He tried twice, and failed. The third attempt would have succeeded, but the kiln collapsed just before the bricks were fully burned. Each effort was attended by increasing signs of rebellion on the part of the students. Brick-making was severe drudgery, and for three successive times their labor had come to naught. Some were disposed to quit outright and return home. Others wrote home in complaint of the drudgery, and the Principal was taken to sharp account for his treatment of boys and girls who were sent to college, and not to slavish labor. Irate parents notified him that their children were no longer slaves and were sent to Tuskegee to study. He replied in consolatory and encouraging terms which satisfied some, but not all. If a student withdrew, he indicated by thus doing that he was not of the class that Washington wished, and his place was soon filled by another who would conform to the regulations.

After some delay in the matter of brick-making, Washington resolved to make still another effort. Not only did the students protest, but some of the teachers joined in objecting to a fourth attempt as 


\section{THE INTEREST DEEPENS}

futile, claiming it had been demonstrated that brickmaking could not be done at Tuskegee. But assuming the responsibility, Washington determined again to try. His money had given out, and he was sorely pressed for just a few dollars with which to make another experiment. Going to Montgomery, he found that he could pawn his watch for fifteen dollars, an amount sufficient for the fourth experiment. With this amount he again tried, and was vindicated in his judgment by the success of the effort-and now he had bricks to sell. The watch was unredeemed and therefore lost to him, but he had the bricks and had found the means of making them. White purchasers of his product would come on the ground to buy, and would thereby become acquainted with his general plan, and thus a new point of contact would be gained. Besides the market value of the bricks, skill and labor had been given the students, and means had been supplied for the erection of buildings for the school. Not a few of his young men seeing the profit in brickmaking became themselves proficient in the art, and, having mastered it, went into different parts of the country and established profitable plants of their own. It came to pass that when it was known that these manufacturers of bricks were from Tuskegee, that was a sufficient guarantee of the value of the product. The points of practical contact with the outlying world were thus multiplying, and the wholesome influence of Tuskegee was increasing.

Though still quite young, crude, and weak, Tuskegee Institute was now fairly on its feet. Slight as 


\section{LIFE OF BOOKER T. WASHINGTON}

the progress had been up to this time it had served the valuable purpose of showing what could be done. The success was at least encouragingly suggestive. The less worthy young people shunned the school because of the labor required, but others sought it as a means of equipment. This meant better and more select students who would contribute to the increased order of the school, and who, in going out from it, would illustrate the type of work done. The officials of Hampton on learning of the growing success of Washington came one after another to note his progress, actuated by the double motive of witnessing the expansion of the industrial idea there inculcated, and of seeing the success of one of their own students.

This was an additional incentive to the enterprising Principal and a wider advertisement of Tuskegee. Success was begetting success. There was no prescribed boundary in the mind of Washington as to the future of the school. His plan was to extend the limits of the crafts and industries to the utmost possible. No sooner was one well established than he would address himself to another. The students must manufacture everything on the ground and construct everything to be used. Bricks would mean additional buildings, and buildings would mean devotion to some industry, and the industry would come to mean independence in the race of life. From the beginning Tuskegee became a hive of industry in books and in handicraft.

The close of the second session found the new building still unfinished. For more than a year it had been 


\section{THE INTEREST DEEPENS}

creeping up by slow stages as money was available to enable the work to go on, and as the students at odd times could devote to its completion a few spare hours. It was at this time that the Principal himself decided to go North in search of possible means with which to carry the building to completion. Heretofore his active and able assistant had done the soliciting, but now both would go, and by their combined efforts make a supreme attempt to procure funds sufficient to finish the much-needed structure. Washington was yet unknown, was young, being only twenty-six, and was naturally timid in pressing his claims. To be able so to present his cause as he himself knew it to be, was a matter of grave concern to the inexperienced solicitor for the needed aid. In his self-distrust he thought to procure a recommendation from a friend of his in New York who was connected with a missionary organization. He supposed the privilege of aiding a colored friend who was doing a work so commendable, would afford delight to the official of the missionary society, but to the utter disappointment of Washington the supposed friend not only declined to indorse the young Principal by giving him a letter, but otherwise discouraged him and advised him to return to Tuskegee at once, make the most of that within reach, and never again undertake to annoy Northern people about money for colored schools. Washington listened in silence, interposing not the least objection to all this gratuitous advice, and then went his way as he originally intended. He relied on the worthiness of his cause, and while he was rewarded 


\section{LIFE OF BOOKER T. WASHINGTON}

with no considerable amount, he was able to make some additions to the growing building.

After the opening of the following session, Washington resolved to celebrate his first thanksgiving at Tuskegee in the chapel of the new but still incomplete Porter Hall. Rev. R. C. Bedford, a white minister of Wisconsin, who was the pastor of the colored Congregational church at Montgomery, was invited to conduct the exercises on Thanksgiving day. The announcement that services were to be held in the new building was heralded through the country, accompanied by a cordial invitation to all to attend, and the result was an overflowing congregation. Till this time the colored people had never observed Thanksgiving, and many attended to learn its meaning. Interest in the school was deepened, the enthusiasm of the colored people increased, and some substantial aid was realized as the result of this first Thanksgiving service in the new building. To Washington it was a gratification that his white friends at Tuskegee shared in the pleasure of the first occupation of Porter Hall.

Among the numerous perplexities encountered at this time by the ambitious Principal was that of the best disposal of the pupils of both sexes who were coming in increasing numbers to attend the school. $\mathrm{Up}$ to this time, these unripe boys and girls who came from the plantations, were forced to find board where they might, and were scattered here and there about the community without oversight, all of which was suggestive of demoralization. Would not a condition 
like this effectually defeat the scheme in the fertile mind of the Principal by immorality to which both sexes would be exposed? To have the students under his immediate eye was his desire, and means must be found for the consummation of this much-desired end. $\mathrm{He}$ would make of the new building a dormitory as far as his means would justify, but how about the boarding? He conceived the plan of excavating the foundation, making a basement, and using this for cooking and dining purposes. Again enlisting the muscular energy of the students, the cellar was dug, and while in its rough condition it more nearly resembled a dungeon than the cooking and eating department of a school, still it was the best that could, at the time, be done. Yet there was still the difficulty of procuring stoves, tables, and table-ware even of the plainest and most inexpensive kind. The students could construct rough tables, use improvised stools and boxes for seats, and as for the cooking, that had to be done on the outside on blazing fires and coals. Spoons, knives, and forks were not to be had except in limited quantity, and these implements would have to be passed from student to student, while at table. While this did not conduce to the development of refinement, it had to serve the present purpose. The test was a severe one both to the Principal and to the students, but the man in the lead felt sure of ultimate success.

While at this period the outlook was a gloomy one, there was no thought of failure on the part of Washington. He had gleaned all possible, it would seem, 


\section{LIFE OF BOOKER T. WASHINGTON}

from friends in the North, and while he had made friends of the whites of the community, they were still poor, and could aid only slightly. The local merchants were willing and glad to give credit to Washington, and urged him to venture, and rely on the future for means to meet his obligations, but he was too wise to go farther than the prospect would justify, and kindly declined the proffered credit. Not only was his reputation at stake, but that of his people, who were altogether too ready to avail themselves of any credit possible, and thus become the victims of the merchant. For the sake of example, if for nothing else, he would not be unduly enticed to purchase. At numerous junctures in his complicated work the temptation was great to overstride in the incurrence of risk, and many times a single blunder on his part would have brought down in a common crash of ruin the unfinished fabric, but the brake of caution was always on the wheel of progress, and he knew just how far to venture. Experience and endowed wisdom were the elements that made the brake. He could not now afford to fail, for on his work reposed the success of millions.

Encompassed by difficulty of every sort Washington was still optimistic. He believed that there was a way out of every difficulty. He counted the cost of each contemplated stride, set the difficulty over against the advantage, and acted on the judgment of the occasion. He was many times effectually stalled, but he made the most possible out of the present, and still hoped for the future. The period immediately 


\section{THE INTEREST DEEPENS}

under review was the most testing time in the experience of the young man. He was standing on the brink, with everything, apparently, against him, yet the fact that he stood and wrestled with giant difficulties showed him to be the man that he was. Without a cent of money, with so many dependent on him, with the difficulties thick about him, without ability to see an inch ahead, he still stood, exhibiting a moral courage rarely witnessed. 


\section{XII}

\section{STILL ACHIEVING, STILL PURSUING}

7 HOUGH Booker T. Washington had been at Tuskegee but little more than two years, he had established a character second to that of no one in the community. His work was the subject of general comment. He was discussed in numerous circles of both races, and the unanimous conclusion was that he was a remarkable young man. The third year came and went with increased elevation in public esteem.

Much as he had done in the general improvement of the grounds and the school, he had accomplished far more by his moral influence. He had extended the scope of his industries, the number of attendants had greatly increased, he had successfully met each emergency as it arose, but in the exercise of a silent influence he had done more. He had brought heart and fresh hope to his people, had infused both inspiration and aspiration, had revealed the possibility and capability of his race, had erected a standard of character and of success, had become an object lesson to a race in despair, had elicited energy and force where he found only apathy, had become a mediator of peace and good-will between the races at a time when passion was the fiercest, had arrested attention when no one of different temperament could have done so, had 
won increased esteem for himself and his people at a period when it would have seemed impossible, and had compelled recognition of Negro merit on the part of even the most prejudiced.

One of the most striking evidences of the greatness of Washington's character was that he kept his own counsel. He had few confidential matters to communicate. Others would talk to him about still others, but he was careful to be silent. He discouraged gossip amc ng his people. Not a few times was he whisperingly: approached with bits of confidential tidings about certain white men, in order that he might be on his gh. ard against them; while he listened, he answered not a yord. Some sought to advise him how to vote, and to impress on him the importance of his taking a prominent lead in certain movements, but he would never con mit himself to anyone, either with respect to his sentments or his purpose. He was gravely informed more than once that if he wished to know how to vote, he could watch the whites, and always cast his vote the other way. This was given him as the controlling rule in the politics of his race. But no one was able to quote him concerning any matter of doubtful question. Indeed he was sometimes accused of doing certain things of which he was entirely innocent, yet he seldom sought to correct their inaccuracy.

When, in later years, there was much ado over the rumor of Washington's having dined with President Roosevelt, he did not undertake to correct the statements which widely obtained throughout the press of 


\section{LIFE OF BOOKER T. WASHINGTON}

the country, and are still quoted as facts. He stated to an intimate friend at the time that there was nothing in it but exaggeration by some omnivorous correspondent at Washington who in his desire to make a "scoop" had spread the report. The occasion which gave rise to the rumor was a very trifling incident. Mr. Washington had occasion to see the President on some matters relating to the school, and $\mathrm{Mr}$. Roosevelt was too busy at the time of his call to give him the required attention, so he asked him to return to his office at noon when he would be privately 1 anching, saying that then he would be glad to go over the matter with him. Washington came at th: time named, and while the conversation was in r rogress the president's luncheon was brought to his office on a large waiter. Remarking that there was sufficient for both, Mr. Roosevelt offered to share with his caller, who could not have declined ard be polite. While they went through the business they ate the limited luncheon, after which Mr. Washington left.

Both the president and Mr. Washington underwent a severe fire of criticism because of the reported formal "dining" at the White House, but neither thought it worth while to explain to the public what actually took place. Why did not Washington publish the facts as they were? To have done so would have raised a storm of controversy, and invectives would have flown like bullets in battle. Once the storm was started it would have passed beyond control. It was Washington's policy never to be betrayed into newspaper controversy. Like other things conjured up 


\section{STILL ACHIEVING, STILL PURSUING 169}

against him, he met this report with silence and suffered the sensation to spend itself.

Each successive step taken at Tuskegee, though logically necessary, involved new difficulty and embarrassment, due to the lack of means. Like all other schools of consequence, that at Tuskegee was a spender of money. No school of worth can exist save as a consumer of means. It gives not back dollar for dollar, in kind, but is a creator of channels, not for money alone but for the things that make for social advancement and financial prosperity. Means from some source had to be created by Booker Washington in response to the demands of advancement. The opening of the modest and unpretentious boarding department at Tuskegee Institute was noised far and wide, and in greater numbers the pupils came trooping in. For all these not only must food be provided but beds also. With all his resources exhausted with his exhausted plans, difficulty and embarrassment increased. In one direction was success, in another was seeming failure. The pressure of the burden was great.

Filled to overrunning as the humble boarding department was, the Principal was compelled to have recourse to renting some neighboring shanties for a large number of boys. These were bare rooms, the walls abounding in open cracks, and the winter nights were bitterly cold. The Principal was doing his best, and he so impressed the students. To a spirit of less nerve this would have been an occasion of despair, but Washington held on, planned on, and labored on. 


\section{LIFE OF BOOKER T. WASHINGTON}

In the midst of these scenes, he would sometimes wake at night and lie listening to the hoarse roar of the wintry winds without, and from sympathy for the boys in the bleak cabins, he would arise, dress, and go to the wretched places. There he would sometimes find a number so grouped over a small fire as to be able to use a common blanket stretched around all, and held tightly by those at each end of the semicircle. He would often sit down with them, offer what cheer he could, and assure them that so soon as conditions could be made better, the suffering students should have the benefit of them. Thus it was that he retained the confidence of the students, none of whom, either while at Tuskegee or after leaving there, was ever heard to utter aught against the sympathetic Principal. The heroism shown by these black boys from the plantation might have been displayed by superior beings, but heroism was never more sublime than here.

As has already been said, this was the most severe testing-time in Washington's life. The conditions were sufficient to appall anyone. The temptation was great to avail himself of the advantage of the credit offered by local merchants, but the fact that he declined to venture into debt redounded, in the end, to his credit. The confidence which he had come to enjoy on the part of the worthy whites of the South was illustrated on one occasion while he was going on a Pullman from Augusta to Atlanta. Just after getting aboard at Augusta, Washington was discovered by two ladies whom he had known in Boston, and to whom 
he was indebted for contributions to his school. He was embarrassed when they invited him to a seat with them. The presence of Southern men on board, in the face of so kind an invitation from two benefactors, threw him into a quandary. There was nothing left but to accept the invitation, be the consequences what they might. But this was not all. After he was seated, dinner was ordered by one of the ladies, and his embarrassment became sorer still.

He noticed that the gentlemen on returning from dinner had gone into the smoking-room, and so soon as he could excuse himself from his Boston friends, Washington sought the smoking-car, as he was sure that if his unavoidable conduct awakened opposition it would be developed in the smoker. To his unspeakable surprise and gratification, on entering the smoking-room, he was kindly greeted by each of the Southern gentlemen, some of whom went so far as to say to the colored principal that he did not know them, but that they knew him. Then they proceeded to congratulate him on his growing success at Tuskegee, advising him of the fact that they were regarding his work with peculiar interest, and assuring him that no one of either race was doing so much for the promotion of race amity as himself.

The thorough disinterestedness of this expression was a peculiar delight to Washington. These could have been none other than expressions of sincerity, and coming as they did from Southern men, without any special occasion to evoke them, they occasioned the profoundest satisfaction. Till then he was not aware 


\section{LIFE OF BOOKER T. WASHINGTON}

that the school at Tuskegee had awakened any public interest. But here were gentlemen of affairs and of wide observation, who were expressing the most encouraging delight in his enterprise and progress. It is a remarkable fact in connection with Washington's career in the South that he was never insulted by a Southern white man. He was many times exposed to conditions when insult might have been expected; he went often through the rural regions where aversion was intense, but no one was ever offensive to him. He was invariably treated with the utmost consideration.

To what was this due? To many ignorant whites he was totally unknown, and yet they accorded to him the utmost courtesy. It was not due to the fact that it was his habit to truckle or fawn, for that would have awakened contempt. None understand the Negro better than the Southerner. Sycophancy on the part of a colored man amuses a Southerner and elicits a bandying of jocularity at the expense of the Negro. The only explanation of the peculiar treatment universally accorded to Washington was that his pearing compelled it. He neither assumed nor cringed, but invariably bore himself with a naturalness and a poise which to have disregarded or disrespected would have been a reflection on the one guilty of such discourtesy. In his frequent intercourse with white .men, whether on matters of business, or in ordinary conversation, they were impressed by the idea that they were not speaking to a colored man, but simply to a man. He gave no impression of borrowed polite- 


\section{STILL ACHIEVING, STILL PURSUING 173}

ness or assumed courtesy, he had no obsequious air, and the consequence was that he received the utmost courtesy. He was free without undue familiarity, agreeable without assumption, and courteous without palaver or the slightest display of servility. He met every man with the civility with which one man meets another. If he was remarkable in this respect, it was only remarkable naturalness.

Whatever may be said to the contrary by vague theorists, the policy of Washington was the only sane one. It embodied the two elements of increasing consideration of the strong for the weak and aspiring, with a growing and responsive strength for the weaker. All transitional periods in individuals and in peoples are trying, both to those who are passing from one stage to another and to those who have to bear the experience. To overcome in both opposing directions was the task set the freedmen of the South when the note of emancipation sounded. They had first to vindicate their claim to fitness in the social framework by unquestioned merit and not by verbal assertion alone. They had to commend themselves before they could command respect. This could not be done by the enactment of formal laws, but must be through the process of natural laws. Other considerations than those of merely barren rights had to be taken into account.

As a matter of judgment and without sacrifice of principle, Booker Washington maintained that in order to permanent solidity of condition for the relations of the races in the South, conciliation must precede cooperation. Without the former of these the latter 


\section{LIFE OF BOOKER T. WASHINGTON}

is impossible; and without the latter, neighborly residence in the states of the South is equally impossible. It is one thing, as he contended, to prate about certain "rights," and continue race strife with only trouble and friction continually ensuing, and quite another thing for the colored race to win its way to confidence and esteem by dint of merit.

$\mathrm{He}$ insisted that the gain by the colored man of the sane and conservative sentiment of the South would bring with it a growing sense of equity and justice which would serve to protect the Negro against an element whose unfriendliness would grow commensurately with the expanding worth of the colored man. $\mathrm{He}$ was fully aware of the fact that as the once enslaved race should acquire self-consciousness and come to take on worthy ambition, antagonism would result with a certain element of whites, Negro advancement would excite unrest because they are hostile to the progress of the colored man.

Frequently demonstrated as this was, an incident which took place on the Georgia Railroad, a few years ago, affords a striking illustration of this unworthy sentiment. The white employees of the road sought to have all colored firemen expelled, not because of inefficiency, but because they were Negroes. What should be done with this aspect of opposition? Just what was then done. A tribunal of white arbitrators to whom the matter was submitted, forthwith reduced the issue to one of equity, and decided, not that the employees of the road should be retained, but that, irrespective of color or aught else, where the authori- 


\section{STILL ACHIEVING, STILL PURSUING 175}

ties should engage a man for a given service, his compensation should be equal to that of every other similarly engaged, and that if his work was satisfactory to the officers of the road, no one should be interfered with in the discharge of his service. This settled a principle finally in the South, and settled it on the basis of merit and of equity.

This is the central principle for which Washington so long labored as the one which would ultimately conduct his people from darkness into light, and in demonstration of this policy, he continued his work at Tuskegee from the outset of his career to its close. By extraordinary skill conditions were produced at Tuskegee within a few years that reversed much adverse theory concerning the Negro race and compelled patriotic acquiescence. The change there wrought was so prophetic of permanent good and so indicative of unlimited benefit to both races, that there came a growing enlistment of interest in behalf of the Negro, interest which was coextensive with the knowledge of the work done at Tuskegee.

While the recognized representative of the colored race, Washington came, after a time, to be thought of as a boon to both races. The development of the inherent qualities of the colored man, as a component part of society, meant much for the white man. One who makes even one man good, makes many better. That which mere wordy argument could not accomplish was being achieved with practical result at Tuskegee. Washington was answering all the ominous predictions concerning the Negro by indisputable fact. 


\section{LIFE OF BOOKER T. WASHINGTON}

$\mathrm{He}$ was arresting current and erroneous theory by tangible demonstration. He was exploding in rapid succession mistaken ideas of the Negro,-by showing that he is not only a man, but one of vast capability. He was silencing the original hoot of ridicule by summoning from the depths of long-buried gloom the latent forces of his people.

It is therefore not a matter of surprise that the thoughtful of the white race came to hold Booker T. Washington in honored esteem. Indeed, he had by his own genius created a condition which logically compelled recognition of his own personal merit and that of the work he was doing in the transformation of character. While steadily commending himself by his course and his work to the public irrespective of race, he was not without opposition on the part of certain leaders of his own people who openly asserted that "the white South naturally agreed with Mr. Washington, and the white North thought they saw here a chance for peace in the racial conflict, and safety in their Southern investments." * Sentiments like these were thrown as so many obstructions in his way, much to his embarrassment. Men like these in the ranks of his own race found their counterpart in the ultra element of the white race, which could see no possible good that could come from the Negro, no matter what was done. But in spite of these limited contentions, the work at Tuskegee went on, and as the institution grew so grew favorable public sentiment. With Washington success was succeeding.

* W. E. B. Du Bois: The Negro, p. 226. 


\section{XIII \\ THE PROSPECT WIDENS}

T $T^{\mathrm{E}}$ come now to contemplate Booker T. Washington after the laborious work of years. For a number of years he labored in restricted obscurity, and was suffered to work out his plans in his own way, the only interest excited being that of seeing the result of his experiment. Even this was known and observed by but few.

The confidence which comes as the result of final success has now arrived. The tangled surface of the hill once crowned by the mansion of a slave owner had largely relapsed into original conditions. The charred ruins of the burnt mansion were overgrown with tangled vines and riotous weeds, and there was a scene of silent desolation unrelieved by the few small buildings left by the fire which had destroyed the original home of the planter.

The whole face of the surface has now been cleared of its débris, the stunted growth that had sprung up has been removed, and the few minor buildings are devoted to valuable service. The adjacent forest has been brought into cultivation, new painted fences surround the patches and gardens, and excellent buildings have come to fill much of the space. Driveways mark the surface, and graceful walks wind here and there amid shady trees, and across lawns em- 


\section{LIFE OF BOOKER T. WASHINGTON}

broidered with grass and flowers. Well-tilled farms, experimental gardens, hot-houses, ranches of different kinds, and all that relates to a great industrial school now extend over a wide area, where a few years ago there were all the signs of abandonment. In the different buildings are groups of well-dressed students of both sexes at systematic work, while beneath the shades are other groups engaged in quiet study. The utmost order and discipline prevail, and the utmost courtesy is shown by all to visitors.

Mr. Washington has already been North a number of times, and a number of friends of the school have visited it as a result of its reputation, and in order to see the man who had wrought such wonders from nothing. The aid with which to establish the institution had been difficult to get at first, but increasing success had made it increasingly easy to obtain funds. Among the many ties that have come to rebind the two sections since the temporary separation of "the sixties," none has been more fruitful of good than that of the service rendered at the most crucial point of the South's overshadowing perplexity, centered at Tuskegee. The dissolution of the general difficulty there begun, and so amazingly fostered by a mediatorial agent who sprang from the ranks of the slaves, deserves the recognition of being perhaps the most distinctive contribution to the rehabilitation of the prostrate South.

Washington had no superficial race pride which he would offensively fleer at the white race. $-\mathrm{He}$ as much desired an amicable relationship between the races as 


\section{THE PROSPECT WIDENS}

he did the elevation of his own people. He came not with observation, but quite the contrary. He wrought not with noisy demonstration of rash thundering and wordy tumult. His was the opposite course. Considering this plan as the dissolvent of the strained condition, he so taught and trained those under his immediate tutelage, and enforced the principle so far as he might among his people throughout the country.

$\mathrm{He}$ was often deeply grieved by the inequality of treatment accorded his people by those possessing force and authority. He was shocked by the awful atrocity of lynching and of other cruel outrages, the power to perpetrate which was derived solely from superiority of advantage. He often insisted that the strong could well afford to be kind to the weak, but he declined to be betrayed into the slightest encouragement of redress by violence. He would protest with all his manhood, but he would not offer resistance. Because of this influence exerted in a way so salutary, at a time so tumultuous, there is due a debt of gratitude on the part of both races, to Booker T. Washington, that can never be canceled. Had the policy pursued by Washington with his great influence among his people, been one of resistance rather than one of conciliation, the results would have been horribly different. He could have inflamed the race as could no other. That he was the man he was, and that he did that which was done, places both races in the South under obligation to him.

During the first years at Tuskegee, Washington sought neither to disguise nor to display himself. 


\section{LIFE OF BOOKER T. WASHINGTON}

Neither of these was to him a matter of concern. He was seeking to work out a practical principle, and to him this was all-engrossing. He would generate the force of initiativeness in his people, and at the same time seek a fair chance for its display. This chance the race had never enjoyed since it set foot on American shores. He was slowly hewing his way through accumulated obstructions in order that his people might find a place in American life where they would be able to demonstrate their ability to contribute to the good of society and of civilization. He was laboring at a point of juncture most important to both races. At such a juncture, with marvelous success attending his efforts, he could not escape observation. In proportion to the growth of his success attention would be diverted from the turbulence of passion which had hitherto swayed the public, to the man who was bringing things to pass. The consequence was that when Washington came to achieve wonders with resources of his own creation, the fact resolved itself into an appeal which could not be disregarded. While creating a condition more favorable for his people, he was at the same time creating a new public situation. In consequence of this, the neighboring whites at Tuskegee, and others beyond the South, came, one by one, and in increasing numbers, to the rescue of the man who was accomplishing so much. In the exercise of his genius he was blending the interests of the two races in a way that would bring mutual helpfulness.

As Tuskegee rose into prominence the attendance 
increased and this, in turn, led to an increase of facilities. The erection of one edifice called for another, just as the introduction of a new branch of industry necessitated the creation of another. As the institution became known, the task of raising funds was not so great, and yet the increasing necessity which called for larger amounts made their procurement more difficult. The consequence was that the labors of Mr. Washington continued to increase as the institution developed. As the pressure of necessity came, he proceeded as if the resources were in hand, as not to do so would check the progress of the school. The means would come in due time, but not without labor on his part. This was true even in the case of the second building to be erected on the grounds. Its cost was estimated at $\$ 10,000$, and without a cent in sight, the work of erection was begun.

It was at this time that he received a letter from his former president, General Armstrong, inviting him to join him on a tour North, in the interest of Tuskegee. $\mathrm{Up}$ to this time, Washington had been but little before the general public. He had a natural shyness, even unto timidity. So far from his vanity being excited by his success, he was rather humbled. Among many others, General Armstrong had visited Tuskegee, and was impressed by its growth and by the dominating force of its great founder, but not till now had the president of Hampton deemed it wise to come to the succor of his former student. Now that Tuskegee had passed the experimental stage and become a permanent fixture, was the time for aid. General Arm- 


\section{LIFE OF BOOKER T. WASHINGTON}

strong could not aid financially, but he could influentially, hence the invitation to Principal Washington to accompany him. To Washington it was at first a sore test to appear before cultured audiences in the great centers of the North, but he had a message and could deliver it as could no other. Together with General Armstrong he appeared in New York, Brooklyn, Boston, and Philadelphia, as well as in other cities, to make his plea for his cause. Introduced as an original slave boy from a Southern plantation, he was presented as a type of that which the colored youth of the South might become if properly and timely aided. His bland face, ease of manner, and readiness of utterance, finding expression in simplicity and vigor, and in power of presentation and graphic description by apt touch of detail, interested a sympathetic public. Without display of emotion he would recite the situation in a way often pathetic and tell of his ups and downs in seeking to meet the demands of a condition so unique. This displayed his native pluck and determination, oneness of purpose, race hopefulness, and freedom from rancor; all these were lighted up here and there with touches of the emotional and glints of inimitable humor, and the listeners were captivated.

Some were present on those occasions who had in former years attended on great gatherings when there was a different kind of appeal made in behalf of the Southern Negro. But here was an occasion quite different. Twenty or more years of freedom had its result here in concrete form. Here was the practical 
result of the liberty then pleaded for. If it was right that interest then be had in the slave encumbered by shackles, how much more important that he be assisted now that he was establishing his ability and need only to be lifted over the rough places? The story told, the hearts of the people were moved. From the simple, unaffected diction of the young educator they could see Tuskegee in its throes as if they were spectators on the ground.

The virtue of the plea of former years, when the physical liberation of the black race was sought, was greatly enhanced when that race plead through its own representative for ability to disentangle itself from the mesh of conditions into which physical liberty had brought the once enslaved. To be now left in that condition would mean but little to the black man, but if now encouraged and guided to that which was within sight, the race would eventually come to take its place worthily among other races. The first emancipation, largely physical, called for a second emancipation, largely mental and moral. Interest in the one should insure interest in the other. If experimental result was needed in order to insure a safe investment in humanity, here it was. The original slave was before them, a convincing argument and advocate.

This first trip North was fraught with immentse consequences. It brought Booker Washington before the public as a revelation of the possibilities of Negro freedom. An insight was afforded into the Southern situation such as had never been given before. The Negro was not to become a ward of the nation as the 


\section{LIFE OF BOOKER T. WASHINGTON}

Indian was. He had force which needed only an outlet. He did not so much need a fish as a hook. The clew was clear-would it be followed? This was the state of reflection occasioned by that visit.

While it meant substantial relief for the stress of the present, it meant more for the future. If under disadvantages so grave the Negro had been able to come thus far, what might he not achieve for the future if timely assistance was his? This meant the uplifting of Tuskegee, which was destined to overshadow all other institutions and interests fostered in behalf of the black race. Its-success meant the final dissolution of race tension in the South. Here was manifestly the dissolvent-to elevate the race to a standard of dignity and merit equal to that already existing for the white race, which would answer all questions, equal all possible demands, and silence the disquietude forever. The plan for doing this had been found and needed only the means to put it into execution. This was the logic of the situation.

The impression produced on the North by this visit of Washington was most profound. It was but the beginning of hundreds of others. He had caught the eye and ear of the people as had no other man of his race. He awoke hopefulness for the future. $\mathrm{He}$ injected fresh ideas. He aroused a sympathy never before entertained for the colored people of the country. He riveted attention with a seriousness never before shown. He brought to the people a new conscience, and his deliverances were of superlative value to the whole country. 
The large new building could now easily go forward to completion. This finished and another, and yet many others, would follow as they were needed. While the intensity of his labors was not diminished, but rather increased, his success was secured. The colored people of the South were inspired by fresh hope and courage, while the whites applauded, and many aided. The points of hostility began to disappear and those of sympathetic contact began to multiply.

Under the efficient management of a corps of teachers who had been trained under his direction, the affairs of the school went along during his absence as when he was present. His impress was on the school, the pace must be kept up in every department, order strictly observed and enforced, and during all the long years of its existence, with him frequently absent from business necessity, there was never an escapade or unbecoming demonstration of any kind on the campus. Not more remarkable is the school itself in its peculiar history than is the fact of the absolute absence of disorder among the students. Its morale accounts for the fact that among its many thousand students who in the succession of years have taken their places in the world, not one of them, so far as can be ascertained, ever fell into serious disorder after quitting the school. The pace there set was kept up in after life. This high standard Tuskegee won within the compass of a few years. While up to the time now under review much had been achieved, it was but the beginning. A hard, long, and laborious struggle still stretched into the years to come. 


\section{XIV}

\section{NATIONAL PROMINENCE}

OR fourteen years Booker $T$. Washington had
been at Tuskegee. By this time the school had
vastly grown in every way. The attendance was now considerably over a thousand, a number of large brick buildings had been erected, the students first making the bricks and then putting up the structures, many departments were in successful operation, outlying and well-tilled farms were adjacent, ranches for stock of different kinds, dairies, gardens, hothouses, water-works and an electric-plant, and other appurtenances were attached, and the entire face of the region had become transformed. The school had now become The Tuskegee Normal and Industrial Institute, and so proficient that it was now famous throughout the country. Its graduates had gone into different states, and in their varied professions had made the school still more famous, while not a few had established schools modeled on that at Tuskegee. By this time, The Tuskegee Normal and Industrial Institute was the most talked-of school in the country.

From having gone North first to solicit funds, the trips of Principal Washington had become frequent in later years, in consequence of the invested funds of the endowment, which had steadily increased as a re- 
sult of the growth of the school. On many occasions he had addressed audiences in the cities of the North and his sentiments had attracted wide attention and evoked much favorable.comment both in the Northern and the Southern press. Up to 1895 he had delivered no address to a popular audience in the South, but on the opening of the International and Cotton States Exposition at Atlanta, Georgia, during that year, he was chosen to be one of the speakers. So great an innovation as that of having a Negro thus distinguished, and he an ex-slave, to sit on the platform with white speakers, both gentlemen and ladies, and deliver an address, awoke wide comment.

Widely divergent conditions at that time prevailed throughout the South. In the current discussions of the time, the Negro came in for his full share. Here and there to the extent of the encouragement given him, he was demolishing all former theories concerning him, was sacrificing much for education, buying land and cultivating it with marked success, building homes, churches, and school-houses, and gaining rapidly in public confidence and esteem, but the subject of the Negro and his elevation was not a congenial one to many ears in the South.

In the central South, Hampton was known but slightly, but right here was a tremendous fact that stood out conspicuously and indisputably-the Tuskegee Normal and Industrial Institute was a great institution, founded and fostered by an ex-slave, where the utmost order prevailed and the most excellent results were achieved. It had won its way by merit, 


\section{LIFE OF BOOKER T. WASHINGTON}

and was most highly prized by those who knew it best. In the old, staid, and refined community of Tuskegee, long noted as an educational center, this colored school had grown to proportions that placed it in advance of schools of established reputation for many years. It would have seemed that at no point could a colored school have encountered more obstructions than at Tuskegee, yet the leading citizens of the town were enthusiastic in their praise of its merits, and readily resented any reflection on the school. Still racial antipathy was widely prevalent, notwithstanding the sentiments of many had been materially changed by the exhibitions of the unquestioned capability of the Negro.

As was to be expected, the invitation extended to a Negro at that time was made the occasion on the part of some newspapers to sound the apprehensive warning that the South was veering in the direction of that everlasting specter, "social equality." While Booker Washington had frequently spoken at the North, only one slight occasion had been afforded him to speak to a white audience in the South. He had spoken before the National Education Association, in which body were many Southerners; in the old historic churches of Plymouth, in Brooklyn, and Trinity, in Boston; before the Twentieth Century Club, Boston, and before the political science club of Cornell University, and elsewhere, with enthusiastic acceptance, and had won wide distinction throughout the North as a speaker of uncommon ability. Nor was he without a certain degree of eagerness to speak 
before an audience in the South, not in gratification of a vain ambition, but in order that he might be able to relieve still more the tension of the times. That which he had succeeded in doing at Tuskegee in practical life, resulting in curbing undue sentiment of hostility, he believed he could effect in another way, if the Southern people could hear him.

There were conditions which favored the invitation to speak at the Atlanta exposition, one of which was that at that time Atlanta was regarded as the most cosmopolitan city in the South. It was seeking to attract capital from all quarters, in the worthy ambition of its people to make it a great city. Much Northern capital had already been invested there, and at that time many Northern people were traversing the South with a view to investment, hence its cosmopolitan spirit. Atlanta would set the pace of national conciliation. It was the home of Henry Grady, than whom the South never had a more sanely conciliatory spirit.

Nor was the spirit of the growing city other than the most worthy. Nothing of marked consequence was expected from the speech of Booker Washington. The mass of the people of Atlanta, or of the South, knew little more of him than that he was an enterprising colored man who had gone to Tuskegee and had built a school for the education of colored people, and that he was succeeding beyond the original expectations of those who regarded the school at the outset. This vague idea and estimate was about all that was known of him. His speech would be brief, 
anyway, and it was easily conceived what kind of speech a Negro would make. Thus much could be afforded for the sake of imparting to the occasion of the exposition the cosmopolitanism which it deserved as a point where an international show was to be had. That the speech would of itself be of any moment, few thought.

Altogether different was it with Washington. To him it would afford an opportunity to say some things which he felt should be said, and becomingly said, by one of his race. He had a message for the people, the people of both races, yea, of all races, and the consciousness that he would be able fittingly to say just the things necessary if the chance were once given him. He desired, as a colored man, to open his heart to all people alike. If an opportunity like this could be his, he believed that he could create a new epoch of sentiment between the two races, white and black. A slight bit of a chance had been afforded him in Atlanta just two years before, but it was altogether too brief to afford an opportunity for a distinctive deliverance that was worth while.

The occasion alluded to was that of the international convention of Christian Workers held in Atlanta in 1893. Washington was invited to be present on the occasion and deliver a talk of just five minutes. The time of the convention seriously conflicted with an engagement which he had in Boston, but so eager was he to be able to speak in the South, that he determined to be present if to speak only five minutes. Though earnestly engaged in Boston, he timed him- 
self to be present at the appointed hour. On examining the schedules of the trains, he found that he could reach Atlanta, remain just one hour, during which time he would speak, and hurry back to Boston. This he did, making a round trip of about three thousand miles in order to make a five minutes' talk. Short though the time for speaking was, he would meet in the convention of Christian Workers influential men and women of both sections, North and South, and he deemed it of sufficient importance to make the sacrifice of time and money. He packed within five minutes just as much as possible in giving at least an inkling of that which he was doing at Tuskegee. But while the little talk was well received, it was far from giving Washington satisfaction.

Doubtless the invitation which came to him to speak at the opening exercises of the exposition was primarily due to that which preceded in connection with a trip to the national capital. A large deputation of prominent Atlanta citizens were to appear before a Congressional committee to ask for an appropriation from the government in promotion of the enterprise. Washington was invited to accompany the party, in which were two other prominent colored men, Bishops Grant and Gaines. The most distinguished citizens of Atlanta, and of Georgia, were in the white contingent of the deputation, to the number of twenty-five. This appearance before a Congressional committee was a novel venture to the young man, and he seriously doubted his ability to contribute to the success of the object of the trip. He was preceded before the com- 


\section{LIFE OF BOOKER T. WASHINGTON}

mittee by several white gentlemen, including the mayor of Atlanta and others of the city officials, as well as by some of the state officers, and the two colored bishops. Washington was the last to be heard.

When he arose to speak it was in a very unostentatious way, but with projectile force. His plea was that if Congress wished to assist in removing the agitation of the race question from the South, and bringing about a condition of race relationship that would be conducive to the good of both peoples, it could not be more effectually done than by encouraging the material and intellectual development of both races. $\mathrm{A}$ rare opportunity for doing this was afforded by the proposed exposition, at which both races would be able to show the progress made since the freedom of the slaves, while the general effect of the exhibition would be to encourage, on the part of both races, continued effort in the same direction. He urged that while the Negro should not be deprived by unfair means of the franchise, still politics alone would not save the Negro, as lying back of the ballot was that which gave to the ballot practical significance and worth-property, industry, skill, and economy, intelligence and weight of character, without the possession of which the race could not advance. Should the appropriation asked for be given by Congress, then something of practical, tangible value would be given, that which would be alike permanent to both races. It was the first opportunity since the close of the war for Congress to manifest an interest in undoing much 
that should not be in the states of the South, and in doing much that should be done.

In a speech of fifteen or twenty minutes he spoke with perfect ease and even with abandon. When he closed the Atlanta delegation grouped about him, congratulated him, expressed absolute satisfaction at the contribution that he had made, and most cordially thanked him for the timely service. With unanimity the committee recommended the appropriation. Just how much that simple talk had to do with the invitation that came later to speak at the opening of the exposition in the fall following, there is no way of deciding.

At any rate, the invitation came in due time. Washington regarded it as one of the golden chances of his life. With the utmost care he prepared his address. He felt profoundly how much depended, not only on that which he should be able to say, but on how he should say it. Perhaps the destiny of his race in the South would depend on that speech. He wrote it and had it well in hand. $\mathrm{He}$ was not without certain misgivings of his success. The pressure of the peculiar condition of the times was on him. $\mathrm{He}$ prayed that he might succeed, not as a means of personal gratification only, but as a means of helpfulness to his people. If he could only succeed, he was sure that a new era would dawn.

The morning came for Principal Washington to leave Tuskegee for Atlanta to deliver the address on the next day. He felt a burden of responsibility never before experienced. That he might have some sup- 


\section{LIFE OF BOOKER T. WASHINGTON}

port for the sentiments expressed in his address, he requested the presence of the faculty that he might read its content to them. If anything was to be added, or omitted, he wanted it frankly stated right there. With emphatic unanimity it was approved throughout by the entire body. This heartened him afresh. But he was to undertake in the South, in her chief inland city, that which no other of his race had ever been called on to do. He could not escape the haunting question, "Suppose you should fail?"

As he was leaving Tuskegee in company with his wife for the train to Atlanta, a white friend, a farmer from the country who lived some distance away, said to him: "Washington, you've got a job on your hands. You have spoken before the whites of the North, the Negroes of the South, and to us country white folks about farming, but when you get to Atlanta to-morrow, you will have all sorts of folks to speak toNorthern whites, Southern whites, and the Negroes all put together. I'm afraid you are going to get into a tight place, old fellow." Washington was feeling just that which his white friend from the country expressed, but he set his face toward Atlanta.

When his train pulled under the car-shed at Atlanta, there had gathered a curious throng eager to see the Negro who was to speak the next morning at the exposition grounds. Curious gazers were pointing him out, and a large crowd of the people of his own race were on hand as eager to see him as any. $\mathrm{He}$ could hear such expressions as, "That's him," "Yonder he is," and a colored teamster regarding him with 
yawning jaws, said in a stentorian voice, "Dat's de man o' my race what's gwine ter speak out yonder at de Expersition to-morrer, an' I'm gwine ter hear 'im shore." Atlanta was jammed with crowds from every quarter of the country.

In flaming headlines the afternoon papers printed the opening event on the morrow. Washington's heart was in his mouth. The supreme moment of his life had come. The night was not a restful one. The early hours were broken by the tramp of crowds, and the cries of newsboys. He ate but little breakfast. In his room alone he paced his floor as the brief time passed, went over his speech, and in his dependence fell on his knees and prayed for strength to meet the serious responsibility of the hour. He prayed for his people, and that his address might be used in some measure to procure their relief. He was alone with his own beating heart and with God.

Soon a committee of colored men appeared to escort Washington to his place in the procession which was to wind slowly out to the grounds under the hot sun. The presence of colored men wearing flashing rosettes, and speaking in exciting tones, did not relieve his nervousness. Negro military organizations, and carriages bearing hundreds of his people had a conspicuous place in the long procession, which crept like a sluggish stream, to the exposition grounds. For a considerable area about the auditorium the scene was one of animation. Thousands were struggling to gain entrance, and were held back by the police. Washington entered from the rear. In the immense 


\section{LIFE OF BOOKER T. WASHINGTON}

inclosure were seated fully fifteen thousand people. $\mathrm{He}$ was greeted by loud cheers from his own people and with only a ripple of applause from the whites, but every eye was fixed on him.

After reaching Atlanta, Washington had learned that many whites had expressed a wish to hear him out of sheer curiosity, simply to see what a Negro would do with himself in a position so unusual and novel; while a few whites were friendly to him, many were going to hear him as they would attend a minstrel show, to see a Negro make a fool of himself. Instead of depressing him, this nerved him with fresh courage. Just thirty-eight years old, and at his best, he was the center of attraction. Besides the opening address by Governor Bullock, and another by a lady, Washington's was the only one of any length to be delivered.

The bustle of preparation over, the bands blared, an ode was sung, and the preceding addresses were made. With guarded caution of expression, Governor Bullock said on introducing the colored speaker: "We have with us to-day a representative of Negro enterprise and Negro civilization, Principal Booker T. Washington, of Tuskegee, Alabama." Wildly greeted by the large contingent of colored people, he stepped to the front, his face perfectly calm, and in voice as clear as the notes of a trumpet, he said:

"Mr. President, and gentlemen of the Board of Directors, and citizens: One-third of the population of the South is of the Negro race. No enterprise seeking the material, civil, or moral welfare of this section can dis- 
regard this element of our population and reach the highest success. I but convey to you, Mr. President and Directors, the sentiment of the masses of my race when I say that in no way have the value and manhood of the American Negro been more fittingly and generously recognized than by the managers of this Exposition at every stage of its progress. It is a recognition that will do more to cement the friendship of the two races than any occurrence since the dawn of our freedom.

"Not only this, but the opportunity here afforded will awaken among us a new era of industrial progress. Ignorant and inexperienced, it is not strange that in the first years of our new life we began at the top instead of at the bottom; that a seat in Congress or in the state legislature was more sought than real estate or industrial skill; that the political convention or stump speaking had more attraction than starting a dairy farm or truck garden. A ship lost at sea for many days suddenly sighted a friendly vessel. From the mast of the unfortunate vessel was seen a signal, "Water, water; we die of thirst.' The answer from the friendly vessel at once came back, 'Cast down your bucket where you are.' A second time the signal, 'Water, water; send us water!' ran up from the distressed vessel, and was answered, ' Cast down your bucket where you are.' And a third and fourth signal for water was answered, 'Cast down your bucket where you are.' The captain of the distressed vessel, at last heeding the injunction, cast down his bucket, and it came up full of fresh, sparkling water from the mouth of the Amazon River. To those of my race who depend on bettering their condition in a foreign land, or who underestimate the importance of cultivating friendly relations with the Southern white man, who is their next-door neighbor, I would say: 'Cast down your bucket where you are '-cast it down in making friends in every manly way of the people of all races by whom we are surrounded.

"Cast it down in agriculture, in mechanics, in commerce, in domestic service, and in the professions. And in this connection it is well to bear in mind that whatever 


\section{LIFE OF BOOKER T. WASHINGTON}

other sins the South may be called to bear, when it comes to business, pure and simple, it is in the South that the Negro is given a man's chance in the commercial world, and in nothing is this Exposition more eloquent than in emphasizing this chance. Our greatest danger is that in the great leap from slavery to freedom we may overlook the fact that the masses of us are to live by the productions of our hands, and fail to keep in mind that we are to prosper in proportion as we learn to dignify and glorify common labor, and put brains and skill into the common occupations of life; we shall prosper in proportion as we learn to draw the line between the superficial and the substantial, the ornamental gewgaws of life and the useful. No race can prosper till it learns that there is as much dignity in tilling a field as in writing a poem. It is at the bottom of life we must begin, and not at the top. Nor should we permit our grievances to overshadow our opportunities.

"To those of the white race who look to the incoming of those of foreign birth and strange tongue and habits, for the prosperity of the South, were I permitted I would repeat what I say to my own race, "Cast down your bucket where you are.' Cast it down among the eight millions of Negroes whose habits you know, whose fidelity and love you have tested in days when to have proved treacherous meant the ruin of your firesides. Cast down your bucket among these people who have, without strikes and labor wars, tilled your fields, cleared your forests, builded your railroads and cities, and brought forth treasures from the bowels of the earth and helped make possible this magnificent representation of the progress of the South. Cast down your bucket among my people, help and encourage them as you are doing on these grounds, and added to education of head, hand, and heart, you will find that they will buy your surplus land, make blossom the waste places in your fields, and run your factories. While doing this, you can be sure in the future, as in the past, that you and your families will be surrounded by the most patient, faithful, law-abiding, and unresentful people that the world has 
seen. As we have proved our loyalty to you in the past, in nursing your children, watching by the sick-beds of your mothers and fathers, and often following them with tear-dimmed eyes to their graves, so in the future, in our humble way, we shall stand by you with a devotion that no foreigner can approach, ready to lay down our lives, if need be, in defense of yours, interlacing our industrial, commercial, civil, and religious life with yours in a way that shall make the interests of both races one. In all things that are purely social we can be as separate as the fingers, yet one as the hands in all things essential to mutual progress.

"There is no defense or security for any of us except in the highest intelligence and development of all. If anywhere there are efforts tending to curtail the fullest growth of the Negro, let those efforts be turned into stimulating encouragement, and making him the most useful and intelligent citizen. Effort or means so invested will pay a thousand per cent interest. These efforts will be twice blessed-blessing "him that gives and him that takes.' There is no escape in the law of man or God from the inevitable:

'The laws of changeless justice bind Oppressor and oppressed;

And close as sin and suffering joined We march to fate abreast.'

"Nearly sixteen millions of hands will aid you in pulling the load upward, or they will pull the load downward against you. We shall constitute one-third and more of the ignorance and crime of the South, or one-third of its intelligence and progress; we shall contribute onethird to the business and industrial prosperity of the South, or we shall prove a veritable body of death, stagnating, depressing, retarding every effort to advance the body politic.

"Gentlemen of the Exposition, as we present to you our humble effort at an exhibition of our progress, you must not expect overmuch. Starting thirty years ago with ownership here and there in a few quilts and 


\section{LIFE OF BOOKER T. WASHINGTON}

pumpkins and chickens (gathered from miscellaneous sources), remember that the path that has led from these to the invention and production of agricultural implements, buggies, steam-engines, newspapers, books, statuary, carving, paintings, the management of drugstores and banks, has not been trodden without contact with thorns and thistles. While we take pride in what we exhibit as the result of our independent efforts, we do not for a moment forget that our part in this exhibition would fall far short of your expectations but for the constant help that has come to our educational life, not only from the Southern states, but especially from Northern philanthropists, who have made their gifts a constant stream of blessing and encouragement.

"The wisest among my race understand that the agitation of the questions of social equality is the extremest folly, and that progress in all the privileges that will come to us must be the result of severe and constant struggle, rather than of artificial forcing. No race that has anything to contribute to the markets of the world is long in any degree ostracized. It is important and right that all privileges of the law be ours, but it is vastly more important that we be prepared for the exercise of these privileges. The opportunity to earn a dollar in a factory just now is worth infinitely more than the opportunity to spend a dollar in an opera-house.

"In conclusion, may I repeat that nothing within thirty years has given us more hope and encouragement, and drawn us so near to you of the white race, as the opportunity offered by this Exposition; and here bending, as it were, over the altar that represents the struggles of your race and mine, both starting practically empty-handed three decades ago, I pledge that in your effort to work out the great and intricate problem which God has laid at the doors of the South, you shall have at all times the patient, sympathetic help of my race; only let this be constantly borne in mind, that while from representations in these buildings of the product of field, of forest, of mine, of factory, of letters and art, much good will come, yet far above and beyond 
material benefits will be that higher good, that, let us pray God, will come in a blotting out of sectional differences and racial animosities and suspicions, in a determination to administer absolute justice, in a willing obedience among all classes to the mandates of law. This, this, coupled with our material prosperity, will bring into our beloved South a new heaven and a new earth." 


\section{XV}

\section{EFFECTS OF THE ADDRESS}

7 HE address was historic. It sounded a note never before heard within the borders of the South. It came from a source least expected, and was magnanimous, serious, pathetic. It was a manly note. Within it lurked no uncertain sound, no implied threat, no trace of murmuring, no undue assertion. It was at once a recognition of the broad principles of a complicated situation, and the remedy for it. No message could have been saner, none sounder. It produced a marvelous effect. Washington's wish was gratified-he had ushered in a new era. When the tall, stalwart man of dusky hue turned to sit down, he was prevented from doing so by an ovation that stirred the vast assemblage. Governor Bullock rushed across the stage and grasped his hand. This was the signal for many others to do likewise. The speaker stood smiling, and gracefully returned the universal greeting. A giant had risen from the ranks of the once enslaved. He had come pleading for peace and good-will among men of all classes. He hailed from a race much misunderstood, much underrated, much abused. On his return trip to Tuskegee, there was a popular ovation all along the way. Throngs of people of both races pressed toward the 
train to shake the hand of the messenger of goodwill.

The result of this notable occasion was both immediate and remote. Directly the effect was electrical, inspiring, hopeful, revelational. Rarely, before, would a white man shake hands with a Negro, but now it was irresistible. In the thrill of the hour, the Negro was a man among men. It was a scene never before witnessed in the South. Another wide rift had been made in the cloud of misunderstanding. But even in advance of this scene there were indications pregnant of immense meaning. During the delivery of the address the vast concourse was a subject of study. Those who had deemed the step an unwise one, gradually underwent a psychological reaction, as the changing expressions of their faces showed. From looks of disgust, but of submissive toleration in obedience to the propriety of the occasion, their faces completely relaxed. Those who had come to witness a farce, a grotesque performance, which would settle forever the folly of injecting a Negro into an occasion like this, were completely disarmed and nonplused. Those who had favored the invitation to Professor Washington were, of course, delighted, while the orderly colored people present were overwhelmed with joy.

The orator was calm and dignified throughout. $\mathrm{He}$ showed no sign of embarrassment, as if seeking to thread his cautious way through a labyrinth of difficulty, halting here, and hesitating there, lest he should let fall some unbecoming and unwelcome word. There was no abjectness to one race in politic words, nor 


\section{LIFE OF BOOKER T. WASHINGTON}

reflection on his own people in order to become the exceptional hero of the popular side; nor was there adroit compromise of view or evasion of principle at any point, but a straight, direct, projectile statement of principles, to question which would react on the commonplace views of ordinary humanity.

Nor could there be even microscopically discerned in manner, matter, or method the slightest effort to escape the task of urging on all alike the opportunity and the responsibility emphasized by the auspiciousness of the occasion. If ever a speaker was heard with intensity it was on this occasion; if ever the words of one were weighed and measured as they fell from his lips, it was when Booker T. Washington delivered his opening address at the Cotton States and International Exposition, at Atlanta, Georgia, on September I8, 1895. In every respect it was a representative audience to which he spoke, made up of every possible phase of society and of humanity. The statesman was there with problems present and to come before him; the publicist, with the current of affairs interrupted here and there by certain obstructions that seemed to defy removal; the philosopher with his vision perplexed by a new order injected politically and sociologically into a once serene situation; the professor with his instructions disturbed by conditions which induced caution while directing the thoughts of the young; the politician with his flexible manner and elastic tongue equally adjusted to all occasions and emergencies; the gospel minister whose sacred function required that if he was to be as his Master, he 
must be no respecter of persons; the editor, who while he must lead, must not unduly offend; the man of business, who, while his thoughts were largely capitalistic, was widely interested in the currents and crosscurrents of public sentiment; the official with his oath binding him to an exactness of duty that placed him beyond discrimination respecting anyone in the administration of his functions; the man from the North and the man from the South with a concrete spectacle of their recent contention directly before them, and, in the aftermath of the struggle, pointing out the way of final deliverance; the refined woman with her delicate sensitiveness of thought and deftness of sentiment, and last of all, both races with their hostility and misunderstanding hitherto in chaos, but now realizing how easy it is to adjust all causes on the basis of equity.

These were the components of the audience gathered on that occasion to listen to the utterances of a late slave who was showing the only way out of the difficulty which a mighty revolution had produced. There was no gainsaying the soundness of his homely philosophy the principles of which had been obscured by the passions of the hour. He was simply recalling just those things without which there was no possible deliverance from the entanglements of the time.

The quiet manner of the speaker after the address, his placid urbanity and general deportment lent to the occasion much additional strength. There was not the slightest show of pomposity, nor the strut of triumph in his air, but rather the quiet bearing of a man who 


\section{LIFE OF BOOKER T. WASHINGTON}

seemed conscious of the fact that he had succeeded in a serious duty under serious difficulty. No place was found for the insertion of a single syllable of adverse criticism. Attention had been keen throughout, and from the heated furnace of a difficult situation he had come forth without even the smell of suspicion or of objection, but rather with the highest praise for a service well done.

The address was equally commended for its exalted sentiment, its philosophical thought, its calm delivery, its pure diction, and its admirable spirit. It was caught up by the press of the country and voiced throughout its borders. Journals North and journals South vied with each other in giving it praise. The Atlanta Constitution bowed to its saneness and wisdom by saying, "It is no disparagement to the others to say that, all things considered, Booker T. Washington's address was the hit of the day." In telegraphing to a metropolitan journal, Hon. Clark Howell said among other things, "I do not exaggerate when I say that Professor Booker T. Washington's address yesterday was one of the most notable speeches, both as to character and as to warmth of reception, ever delivered to a Southern audience. The address was a revelation. The whole speech is a platform upon which blacks and whites can stand with full justice to each other." Editorially the Boston Transcript said, "The speech of Booker T. Washington at the Atlanta Exposition this week seems to have dwarfed all the other proceedings and the Exposition itself. The sensation that it has caused in the press has never been equaled." 
Throughout the country this was the dominant tone of the press. Its notes continued to linger for weeks and seemed to die out with reluctant subsidence. It became the topic of many circles, a subject of favorable comment on the part of the public. As a note of timely sentiment and as a classic it passed into the realm of the world's famous orations. The praise evoked by the address would have upset an ordinary man, but the next day Washington might have been seen in his ordinary treadmill at Tuskegee going about his work as though nothing unusual had occurred. Not only did congratulations pour in from every quarter, but enticing offers reached the man in his comparative retreat on his farm outside the little town of Tuskegee. Magazines offered tempting inducements to him to write for their pages, bureaus and lyceums urged him to accept proposals to go on the platform, one going so far as to offer him $\$ 50,000$ for his services, and still another making the offer of $\$ 200$ a night and all expenses paid. He was a poor man, laboring hard in a hard sphere, and these blandishments were glittering prizes to be dangled before him in a supreme moment like this. He stood on the step of fame and fortune. To the majority of men the temptations offered would have been far too great for their integrity.

But what did Booker Washington say and do? With quiet courtesy he duly thanked each for the proffers made, and modestly replied that his chosen life-work was for his struggling race at one of the great central stations of race stimulation and eleva- 


\section{LIFE OF BOOKER T. WASHINGTON}

tion. His simple declination embodies words worthy of immortality. The value to the world of his conduct on that occasion is above that of rubies. His words deserve a place alongside those of General Robert E. Lee, who, when offered the presidency of a metropoli$\tan$ insurance company at a salary of $\$ 50,000$, blandly replied in his poverty that he knew nothing of insurance business; and when, with commercial frankness, he was told that his skill was not so much desired as his name, and that he need do nothing, he declined, put aside the tempting offer, and accepted the presidency of a small and struggling college, giving expression to his dominant sentiment in this memorable passage, "I have a self-imposed task which I must accomplish. I have led the young men of the South in battle, and have seen many of them fall under my standard. I shall devote my life now to training young men to their duty in life." The two instances are almost parallel in the spirit of nobleness and of self-abnegation. General Lee had known wealth, and chose poverty from a high sense of duty; Professor Washington had never known what it was to have wealth, but he would not hazard the opportunity of doing a work for millions who needed aid, though fortune was offered to desist from such work as he was doing. $\mathrm{He}$, too, thought of the coming youth of a race. That youth needed assistance in climbing the toilsome ascent to worth. $\mathrm{He}$ would, therefore, turn aside from the dazzling offers made, to serve others of the generation present and to come.

In response to a note from Professor Washington, 
President Cleveland, to whom was sent a copy of the Atlanta address, wrote as follows:

\section{Gray Gables, Buzzard's Bay, Mass.,}

Booker T. WAShington, Eso.,

October 6, 1895 .

My DEAR SiR:-I thank you for sending me a copy of your address delivered at the Atlanta Exposition. I thank you with much enthusiasm for making the address. I have read it with intense interest, and I think the Exposition would be fully justified if it did not do more than to furnish the opportunity for its delivery. Your words cannot fail to delight and encourage all who wish well for your race; and if our colored fellowcitizens do not from your utterances gather new hope and form new determinations to gain every valuable advantage offered them by their citizenship, it will be strange indeed.

Yours very truly,

Grover Cleveland.

This was written by Mr. Cleveland with his own hand on dainty note paper.

Up to that time Principal Washington had never seen Mr. Cleveland, but later he met him at the Atlanta Exposition on the occasion of the President's visit. Mr. Cleveland took occasion to renew his expression of esteem for Mr. Washington and for the work that he was doing, at the same time expressing much interest in the colored race by visiting the colored building, and spending considerable time in inspecting the exhibit there made by the colored people. With the genuine democratic simplicity for which Mr. Cleveland was noted, he would shake hands with the humblest Negro, and make kindly reply to the 


\section{LIFE OF BOOKER T. WASHINGTON}

grotesque, simple, but sincere politeness with which he was greeted. With the utmost readiness and affableness he would write his autograph for them on scraps of paper or old envelopes, or in some old book, that they might retain it as a keepsake.

The reputation gained by Washington in consequence of his address was evidenced from many prominent quarters. He received the following letter from Dr. Daniel Coit Gilman, President of Johns Hopkins University, who had been made chairman of the judges of award at the Atlanta Exposition:

Johns Hopkins University, BaltimoRe,

President's Office, September 30, 1895.

Dear Mr. Washington:- Would it be agreeable to you to be one of the Judges of Award in the Department of Education at Atlanta? If so, I shall be glad to place your name upon the list. A line by telegraph will be welcomed.

Yours very truly,

D. C. Gilman.

The thrill produced by the address subsided into a quiet calm, which was broken in one or two instances by a complaint on the part of some of the would-be leaders of Washington's own people. Seemingly from the sting of envy there came the remarkable statement that after all there was but little in the speech for the good of the colored race. Detached passages were severed from their logical connection and paraded in vindication of the assertion of the jealous, and with an evident attempt to disparage the merit of the famous address. A jealous man always finds 
more than he looks for. How there could have been tortured from that address that which certain persons claimed to find, is amazing. The studied distortion was made the basis of an accusation that Washington was shrewdly pandering to white sentiment in total disregard of the good of the colored race. The accusation continued, but the colored race itself declined to be thus led into lack of appreciation; and be it said to their credit that they continued to cling to Washington to the end as their leader, and turned a deaf ear to the few whose envy did not cease to find vent in every way possible through the years of the future. The Southern Negro knows the Southern white man, and none knows the Negro better than the white man of the South. Each equally recognizes the wrong done the Negro, often clandestinely, under the cover of night, the chief shield of bad men always; and while the rights of the Negro have not always been respected, it is not due to the best and the most thoughtful whites of the South. But such, in the colored race, are yet in the minority. Among the abuses of democratic free speech none is more conspicuous than that of the utterances of the cheap clatterer and designing demagogue on the political stump, whose ravenous appetite feeds with avidity on the wrongs of the oppressed in summoning to his support the ruffianism and the thoughtlessness of different localities. The attempt to disparage the address of Dr. Washington signally failed, for it became a landmark in Southern history.

That Booker Washington would do just that which 


\section{LIFE OF BOOKER T. WASHINGTON}

an exceptional few of his own race insisted he should have done on the occasion of his address at Atlanta, was the expectation of some whites who had gone to the opening exercises to witness the folly. To the disappointment of both, however, in the ripeness of his wisdom, he diverted his deliverance into the channel unexpected. He built his speech on the wide basis of humanitarianism which applied to both races in practical conditions, and not only put it beyond the pale of objection, but struck telling blows for his own people. Thenceforward not Washington alone but numerous other men of his race were gladly heard, and not without effect.

Washington had reached the point where he did not have to seek an opportunity to speak to the whites of the South. He was in actual demand. $\mathrm{He}$ was as gladly heard in one region of the country as in the other. As never before he became the mouthpiece of his people, and anything he said claimed attention. His contributions to the press were gladly published, he was sought out for interviews, and was heeded, since it came to be known that there was a force behind his words. Oftener than he himself knew he controlled public thought by a single expression. $\mathrm{He}$ was quoted here and there with a weight of authority that often preponderated in favor of his people. $\mathrm{He}$ was taken into the counsel of white men in the consideration of questions in which both races were interested. In some instances, his influence extended to the highest councils of the nation, and more than once he became a decisive factor in emergencies, That he 
should have thus won is not surprising, since he was seen to be an extraordinary man. Color was not taken into account, when men came to confer with him. Indeed, as one of the direct results of his address, he could thereafter give more candid expression of sentiment concerning his people than before. He was respected because of his sincere force and influence, and he was not menaced by a lurking suspicion that what he might say had within it a sinister purpose.

( In his estimate of the effect of an address to a representative white audience in the South, he found himself correct. He saw the tension slackening, the barriers heretofore existing now giving away. It was cheer ing to see how gratified were the best whites with the coming change, and to note that where alienation had been there was now often to be seen the spirit of cooperation between members of the two races. On the part of both, expressions of unkindness had given place to those of friendship.

It was not, of course, that Washington acquiesced in all that was done to his people, for violence was still abroad, and much there was yet to do; but if he could not effect the desired end in a spirit of conciliation, and if he could not fully arrest the wrongs done, it was certain that these ends could not be attained by clamor or noisy abuse. With the calmness of a sage he studied the situation throughout, and when the opportune time came, he spoke in no uncertain way, and always with effect.

(What, then, was the general gain of the notable 


\section{LIFE OF BOOKER T. WASHINGTON}

address delivered at Atlanta? For one thing, it won for the colored race a position in public esteem never before even approximated. It afforded an insight into the forces of Negro capability which had all along been obscured by an unpardonable and unreasonable prejudice. It was the beginning of obtaining for the Negro a place in American life. Whatever the merits of the race, so long as they were obscured they must remain unknown. It was Booker $\mathrm{T}$. Washington who took the veil off the face of misconception, ignorance, and prejudice. To be sure he did not accomplish everything for the race, but that which he alone did was necessary to be done before other things could be made possible.

The address gave him national prominence, Negro as he was, erstwhile slave as he was, and while this may be accounted by some as small, it was vast gain for the American Negro. It would indeed have been phenomenal had he achieved all that was to be for the colored people by a single act. That he did not, nor could it have been done by any, but he removed the stone from the mouth of the tomb, and made possible the emergence of his race into a new life. The event passed and was not even known to many of a later generation, but its influence still abides. The strides made by his people since that time run back in logical connection to Washington's address at Atlanta. ) 


\section{XVI}

\section{HONOR FOLLOWS WORTH}

MONG the direct results of the Atlanta address
was that of turning toward Mr. Washington whom had heard of him only in a casual way, as a colored man who had founded a school for his race in the lower South. The address proved him to be a man of extraordinary parts, and inquiry was awakened which led to closer and clearer investigation of the man and his work.

The recognition accorded him by a great institution of learning during the summer following the Atlanta address was so distinctive, as to deserve here space for an account of it in detail. It was not presumed by any, and least of all by Professor Washington himself, that the address would lead to academic honorsfrom the oldest and most eminent institution of learning in the American states. Washington's sole ambition had been to make a sane deliverance before a representative Southern audience, in order that the proper view of the race question might be presented from the side of the colored people. Up to this time only one side of the question had been heard, and public opinion was warped in a direction very detrimental to his race. 


\section{LIFE OF BOOKER T. WASHINGTON}

His expectations having been fully realized by the nature of the reception given his speech, he was nerved by a stronger purpose to persevere as never before. But appreciation from an unexpected source was revealed in the following letter:

Harvard University, Cambridge, May 28, 1896. President Booker T. Washington,

My DeAR SiR:- Harvard University desires to confer on you at the approaching Commencement an honorary degree, but it is our custom to confer degrees only on gentlemen who are present. Our Commencement occurs this year on June 24 , and your presence would be desirable from about noon till about five o'clock in the afternoon. Would it be possible for you to be in Cambridge on that day?

Believe me with great regard,

Very truly yours,

Charles W. Eliot.

This was the greatest surprise of his life. He prized the recognition of kindness and courtesy, but the thought of recognition by a great institution of learning was as remote from his mind as possible. As he held in his hand the letter from the president of America's most renowned, as well as her oldest, institution of learning, his life rose before him. The memories of his slave days, his work among the lime kilns and in the coal mines, his hunger and lack of clothing, his struggles to obtain an education, his night under the plank sidewalk in Richmond, his privations at Hampton, his first efforts at Tuskegee, and the suffering of heart which he had undergone, and now to be recognized by Harvard University as one worthy 
of an academic degree, was more than he had ever dared to dream. As he held the letter and reread it, he wept as he sat alone on his veranda at Tuskegee. $\mathrm{He}$ had never aspired to fame, and all that had come to him he had sought to turn toward the accomplishment of his life's aim-that of the good of his people. If this could conduce to that end, he would accept it. It was another indication that things were growing better. Not only were passions cooling, but it was actually coming to pass in democratic America that the worthy were honored in proportion to the estimate placed on each, and here was a concrete illustration of the fact. To him the incident was more notable because of the Negro race in general, than because of any personal distinction shown to him. He saw in it a prophecy of the coming recognition of the merit of his race.

To Washington this was the consuming idea of life. He had always felt that in the long run humanity was fair. The Anglo-Saxon might be stern and arrogant, proud of his race and of his station in the world, but after all, he was usually not only fair, but generous. He had a heart and judgment that needed only to be convinced, and other conditions would follow. It was the mistaken colored man, the unruly, the lawless, that brought the race into most of its trouble. Cruelty was sometimes meted out by unworthy whites, but they were not representatives of the highest type. And even these were actuated frequently by that done by unworthy Negroes who were taken as representatives of the colored people. While he deplored con- 


\section{LIFE OF BOOKER T. WASHINGTON}

ditions in the South which made this possible, he could not recall a single instance where a really worthy colored person was not protected by white friends when such were needed. The humblest washerwoman, if she were worthy, could gain the confidence of those who would become her protectors. He insisted that this was the policy to be pursued by the colored people of the South, and he so taught to the end.

On the date named in the letter of President Eliot, June 24, Washington was in Cambridge; he met the president of the university, the board of overseers of the institution, and other distinguished attendants on the occasion, and, with others who were to be the recipients of honors, was escorted to the hall where the exercises were to be held. Among those invited to the Commencement for the purpose of having honors bestowed on them were distinguished men like General Nelson A. Miles, Alexander Graham Bell, of telephone fame, Bishop John Heyl Vincent, the founder and chancellor of Chautauqua, and Rev. Minot J. Savage.

The conferring of degrees is the most interesting occasion in connection with Commencement exercises at Harvard. Those to be honored are not known till their names are announced. As each distinction is bestowed, it is greeted by the applause of the students and the brilliant audience, in proportion to the popularity of the recipient. When the name of Booker Taliaferro Washington was called the applause was tremendous throughout the great hall. In a few words 
of vigorous diction Professor Eliot conferred on him the degree of Master of Arts.

After the interesting exercises had closed, the recipients of honors, together with a few other guests, were invited to lunch at the home of the president of the university. Among the speakers here were President Eliot. Governor Wolcott, General Miles, Senator Cabot Lodge, Dr. Minot J. Savage, and Principal Booker T. Washington. When called on, Dr. Washington arose and said:

"It would in some measure relieve my embarrassment if I could even in a slight degree feel myself worthy of the great honor which you do me to-day. Why you have called me from the Black Belt of the South, from among my humble people, to share in the honors of this occasion, is not for me to explain; and yet it may not be inappropriate for me to suggest that it seems to me that one of the most vital questions that touch our American life is how to bring the strong, wealthy, and learned into helpful touch with the poorest, most ignorant, and humblest, and at the same time make one appreciate the vitalizing, strengthening influence of the other. How shall we make the mansions on yon Beacon Street feel and see the need of the spirits of the lowliest cabin in Alabama cotton-fields or Louisiana sugar bottoms? This problem Harvard University is solving, not by bringing itself down, but by bringing the masses up.

"If my life in the past has meant anything in the lifting up of my people and the bringing about better relations between your race and mine, I assure you that from this day it will mean doubly more. In the economy of God there is but one standard by which an individual can succeed-there is but one for a race. The country demands that every race shall measure itself by the American standard. By it a race must rise or fall, 
succeed or fail, and in the last analysis mere sentiment counts for little. During the next half-century and more, my race must continue passing through the severe American crucible. We are to be tested in our patience, our forbearance, our perseverance, our power to endure wrong, to withstand temptations, to economize, to acquire and use skill; in our ability to compete, to succeed in commerce, to disregard the superficial for the real, the appearance for the substance, to be great and yet small, learned and yet simple, high and yet the servant of all."

This is the substance of what he said on that notable occasion, the more notable because it was the first instance in which a New England university had ever conferred an honorary degree on a Negro. The sober- ness and the wisdom of Washington's address at the luncheon struck the country with great force. Here was the type of the possible Negro of the future. Here was one who had emerged from the lowliest station, who was recognized by the leading university of the continent as one worthy of its honors. Washington was not an anachronism, he was an index. He had been raised up to show the possibilities of the race. His was an appeal for consideration soberly and wisely made. He was not apologizing for being a colored man, he was soliciting from the source of domination the consideration which would yield to the black man a chance. While he had made his own chance by dint of merit, the conditions of his people were such that this could not be true of everyone, except by the high having respect unto the humble. That which he exhibited was an earnest of that which the world might expect of multitudes of others. 
The bestowment of this title on Washington was so exceptional and unique that it created a sensation. A correspondent of a cosmopolitan journal writing in description of the occasion said: "When the name of Booker T. Washington was called, and he arose to acknowledge and accept, there was such an outburst of applause as greeted no other name except that of the popular soldier patriot, General Miles. The applause was not studied and stiff, sympathetic and condoling; it was enthusiasm and admiration. Every part of the audience from pit to gallery joined in, and a glow covered the cheeks of those around me, proving sincere appreciation of the rising struggle of an exslave and the work he has accomplished for his race."

In a similar strain a Boston daily wrote editorially: "In conferring the honorary degree of Master of Arts upon the Principal of Tuskegee Institute, Harvard University has honored itself as well as the object of this distinction. The work which Professor Booker $\mathrm{T}$. Washington has accomplished for the education, good citizenship, and popular enlightenment in his chosen field of labor in the South entitles him to rank with our national benefactors. The university which can claim him on its list of sons whether in regular course, or honoris causa, may be proud. Mr. Washington is the first of his race to receive an honorary degree from a New England university. This, in itself, is a distinction. But the degree was not conferred because Mr. Washington is a colored man, or because he was born in slavery, but because he has 


\section{LIFE OF BOOKER T. WASHINGTON}

shown, by his work for the elevation of the people of the Black Belt of the South, a genius and a broad humanity which count for greatness in any man, whether his skin be white or black."

Still another Boston daily said: "It is Harvard which, first among New England colleges, confers an honorary degree upon a black man. No one who has followed Tuskegee and its work can fail to admire the courage, persistence, and splendid common sense of Booker T. Washington. Well may Harvard honor the ex-slave, the value of whose services, alike to his race and country, only the future can estimate."

The Boston correspondent of the New York Times wrote to that journal thus: "All the speeches were enthusiastically received, but the colored man carried off the oratorical honors, and the applause which broke out when he had finished was vociferous and longcontinued."

These are only samples of the comments of the press throughout the country. The proper recognition of himself personally, and of his race prospectively, is shown in these comments. There is suggested here that with proper encouragement and patience, instead of restlessness and fault-finding, there are possibilities in the Negro race which to help will be for the common weal, while to hinder will inevitably have the effect of public detriment.

It was in December, I897, that President McKinley paid a visit to the South to attend, at Atlanta, Georgia, the Peace Jubilee, in commemoration of the successful issue of the conflict between America and Spain. 
On learning of his proposed visit, Dr. Washington went to the national capital, in November, to invite the president to visit his school. He acknowledged that it was among the ambitions of his life to build up such an institution as would be worthy of a visit from the President of the United States. The interview with the President did not result in a promise to visit the school, but he showed great interest in the enterprise, and agreed to consider the matter of a visit. Soon after, there were several sporadic outbreaks of race violence in the South, the result of tolerated ruffianism too often regarded with indifference when it should have prompt official and just attention-and these tended to impair the prospect of the President's visit to the school.

However, Dr. Washington went again to visit the President at the White House in regard to the visit to Tuskegee, but again he declined to commit himself, wishing to wait until he should reach Atlanta to decide. When he came to Atlanta, Washington again urged him to extend his visit to Tuskegee, insisting that nothing would so aid him in his racial work as an indorsement like that from the chief executive of the nation. The President wished to go, but was doubtful of the wisdom of the step, not being sure how it might impress the people of the South. While he was discussing the matter with Washington, a prominent gentleman of the South, an original slave-holder, came in, and the President referred the matter to him for advice. The gentleman said that a visit to the South would not be complete without seeing the wonderful 


\section{LIFE OF BOOKER T. WASHINGTON}

school at Tuskegee, and urged the President, by all means, to go. This was re-enforced by the persuasion of Dr. J. L. M. Curry, who happened also to be present. The result was the promise of Mr. McKinley to go to Tuskegee on December I6th.

With this assurance Washington hurried back to Tuskegee, made the fact known, and soon the town fwas agog over the promised visit. The white population became as much interested as the blacks. Both men and women of the whites began the formation of committees for the decoration of the town, and all placed themselves at the service of Dr. Washington to do as he might wish in preparing for the distinguished event. Bunting was provided in profusion, arches were erected, flags were got in readiness, and all the ornamentation necessary was provided, the races vying with each other, under the general direction of Dr. Washington.

In order to afford a practical display of the school and its work to the presidential party on its arrival it was arranged to have the great body of colored students pass in array before the President. Each was significantly to carry a stalk of sugar-cane, borne as a musket, with several bolls of cotton tied to the upper end of each cane. Following the students came the several departments of the school represented by floats drawn by horses, mules, or oxen, all the property of the Institute. These floats not only represented the present work done, but, in contrast, on each were exhibited the old methods, showing to the eye the advancement of the colored school beyond that which 
had been. For an hour and a half these floats passed in review before the distinguished guests.

The morning of December 16 th dawned bright and beautiful, and in due time the train arrived bearing the presidential party. Besides the President and Mrs. McKinley there were the members of the cabinet and their wives, and a number of leading generals in the late war with Spain, including Wheeler and Shafter. The legislature of Alabama, in session at the time, adjourned, and came in a body to join in the festivities of the occasion. The little town of Tuskegee was thronged as never before. Vast multitudes filled the grounds and streets, and adjacent environs. The order throughout, under Washington, was complete. Brass bands were in evidence, flags floated, bunting shone, and the occasion was one of quiet splendor.

The parades being at last over, the throngs repaired to the new and spacious chapel that had just been completed, and President McKinley, introduced by Dr. Washington, said in part:

"To meet you under such pleasant auspices and to have the opportunity of a personal observation of your work, is indeed most gratifying. The Tuskegee Normal and Industrial Institute is ideal in its conception, and has already a large and growing reputation in the country, and is not unknown abroad. I congratulate all who are associated in this undertaking in the good work which it is doing in the education of its students to lead lives of honor and of usefulness, thus exalting the race for which it was established. Nowhere, I think, could a more delightful location have been chosen for this unique educational experiment, which has attracted the 


\section{LIFE OF BOOKER T. WASHINGTON}

attention and won the support, even, of conservative philanthropists in all sections of the country.

"To speak of Tuskegee without paying special tribute to Booker T. Washington's genius and perseverance would be impossible. The inception of this noble enterprise was his, and he deserves high credit for it. His was the enthusiasm and enterprise which made its steady progress possible, and established in the institution its present high standard of accomplishment. He has won a worthy reputation as one of the great leaders of his race, widely known and much respected at home and abroad as an accomplished educator, a great orator, and a true philanthropist."

Addresses were also delivered by Hon. John D. Long, secretary of the navy, and Hon. Charles Emory Smith, postmaster-general in Mr. McKinley's cabinet. After the return of the party to Washington, the Principal of Tuskegee Institute received the following letter from the President's secretary:

\section{Executive Mansion, Washington,}

December 23, 1897 .

DEAR SIR:-By this mail I take pleasure in sending you engrossed copies of the souvenir of the visit of the President to your institution. These sheets bear the names of the President and the members of the cabinet who accompanied him on the trip. Let me take this opportunity of congratulating you most heartily and sincerely upon the great success of the exercises provided for the entertainment furnished us under your auspices during our visit to Tuskegee. Every feature of the program was perfectly executed and was viewed, or participated in, with the heartiest satisfaction by every visitor present. The unique exhibition which you gave of your pupils engaged in their industrial vocations was not only artistic but thoroughly impressive. The tribute paid by the President and his cabinet to your work was 
none too high, and forms a most encouraging augury, I think, for the future prosperity of your institution. I cannot close without assuring you that the modesty shown by yourself in the exercises was most favorably commented on by all the members of our party.

With best wishes for the continued advance of your most useful and patriotic undertaking, kind personal regards, and the compliments of the season, believe me always,

$$
\begin{aligned}
& \text { Very sincerely yours, } \\
& \text { JoHn ADDISON PoRTER, } \\
& \text { Secretary to the President. }
\end{aligned}
$$

About the same time that this visit of President McKinley to Atlanta took place, peace demonstrations were popular throughout the country, none of which exceeded either in proportion or grandeur the one held at Chicago. President William R. Harper of the University of Chicago was the chairman of the committee on invitations and, among others, he invited Dr. Washington to deliver an address. The occasion was a notable one, President McKinley and his cabinet, and many army and navy officers who participated in the struggle, being present, besides a number of foreign ministers. The cosmopolitan character of the occasion seems to have suggested the character of the speakers, who were President John H. Barrows of Oberlin College, Rabbi Emil G. Hirsh, Rev. T. P. Hodnett, a Catholic priest, and Booker T. Washington.

The exercises were held in the Auditorium, and the gathering was an immense one. President McKinley was seated in a box at the right of the stage. When Washington spoke all else seemed to be forgot- 


\section{LIFE OF BOOKER T. WASHINGTON}

ten. The Chicago Times-Herald gave this account of the effects of Washington's address:

"He pictured the Negro choosing slavery rather than extinction; recalled Chrispus Attucks shedding his blood at the beginning of the American Revolution, that white Americans might be free, while black Americans remained in slavery; rehearsed the conduct of the Negroes with Jackson at New Orleans; drew a vivid and pathetic picture of the Southern slaves protecting and supporting the families of their masters while the latter were fighting to perpetuate black slavery; recounted the bravery of colored troops at Port Hudson and Forts Wagner and Pillow, and praised the heroism of the black regiments that stormed $\mathrm{El}$ Caney and Santiago to give freedom to the enslaved people of Cuba, forgetting, for the time being, that law and custom made against them in their own country.

"In all these things, the speaker declared, his people had chosen the better part. And then he made his eloquent appeal to the consciences of the white Americans: "When you have gotten the full story of the heroic conduct of the Negro in the Spanish-American War, have heard it from the lips of Northern soldier and Southern soldier, from ex-abolitionists and exmasters, then decide within yourselves whether a race that is thus willing to die for its country should not be given the highest opportunity to live for its country.' "'

At one stage of his speech, while the enthusiasm was highest, he thanked the President for his recognition of the Negro in his appointments during the 
Spanish-American War. The passage was uttered with so much pathos and burning earnestness that the vast audience arose as one man, yelling and shrieking, while they waved hats, handkerchiefs, canes, and umbrellas, so that the President had to arise and acknowledge the demonstration.

One portion of the address was misinterpreted by the press of the South. Allusion was made to the right of the Negro to live in the full enjoyment of his rights. The quotation and accompanying misinterpretation went the circuit of the Southern press, to all of which, according to his habit, Washington gave no heed, until the editor of the Age-Herald, at Birmingham, Alabama, asked an explanation of that part of his speech. This led Washington to reply that he did not deem it necessary to go into detailed explanation of what he had said, for if seventeen years of the character of the work he had done right in the heart of the South was not an ample answer as to what he meant he did not think that words would explain it. He further said that it had been an invariable rule of his to say nothing in the North which he would not say in the South. $\mathrm{He}$ referred to his address at Atlanta, and stated that what he said at Chicago was the same in spirit, and had reference to the obliteration of race prejudice in "commercial and civil relations." $\mathrm{He}$ further explained that what is known as "social recognition" was a question never discussed by him anywhere, and recalled what he had said at Atlanta on that subject. This closed the discussion of the matter, and no further question was ever raised concerning his position. 


\section{LIFE OF BOOKER T. WASHINGTON}

Many other addresses were made by him throughout the country, South and North, after this, but he was never again called to account because of his utterances. The confidence in the man and in his mission was complete, as was shown by the elevated classes of society who listened to him gladly. 


\section{XVII}

\section{WIDENING INFLUENCE AND INCREASING POWER}

DOOKER T. WASHINGTON had now become a national figure. He was equally known in every quarter of the Union. He had attained a distinction never before held by a Negro. His greatness was appreciated everywhere. His influence was potential. Sketches of his career appeared in the papers and magazines throughout the country. Only a few were disposed to modify the estimate of his importance by the expression that that which he did was excellent-“" for a Negro."

On one occasion, after he had spoken to an immense crowd in a Southern city, an audience composed of both races, three gentlemen were walking away from the hall when one of them remarked that the address was a most remarkable one. Another said in rather a disparaging way, "Yes, that does pretty well for a Negro." The third remarked that he was a philosopher, and asked if the disparager had ever heard anyone who did better. $\mathrm{He}$ acknowledged that it was remarkably good, when it was further insisted that to undertake to modify it was not fair, and that the address would have been ranked great no matter by whom delivered. Washington had caught the atten- 


\section{LIFE OF BOOKER T. WASHINGTON}

tion of the entire country, and his race was the chief beneficiary.

In the colored race there were men far more scholarly than he, others more fascinating orators, but in the combination of great forces, he was peerless among his people, and ranked with the foremost of any race. The advantages which had been given to others of his race in educational culture stood in marked contrast with the advantages which Washington had had to create for himself. He was emphatically a self-made man. His disadvantages at every stage of his career had been enormous and grave, and it was by mastering these that he came to great prominence. His knowledge of life was from within. Experience had ripened him, and solid good sense enabled him to formulate principles of conduct for his own guidance and for that of others. "Experience joined with common sense to mortals is a providence." The rules which experience suggests are better than those which theorists elaborate in their libraries.

All along, certain silent movements had been operating which culminated in the vindication of the force of the colored race in Booker T. Washington. For a number of years, the Negro had not been without pronounced friends, even in the heart of the South. These quiet forces were dissociated and largely local, but in each instance were thoroughly disinterested. Even at a period when one hazarded much, especially of personal reputation, to espouse the cause of the blacks, there were those of a slave-holding generation who knew the Negro, and who, braving all opposing 


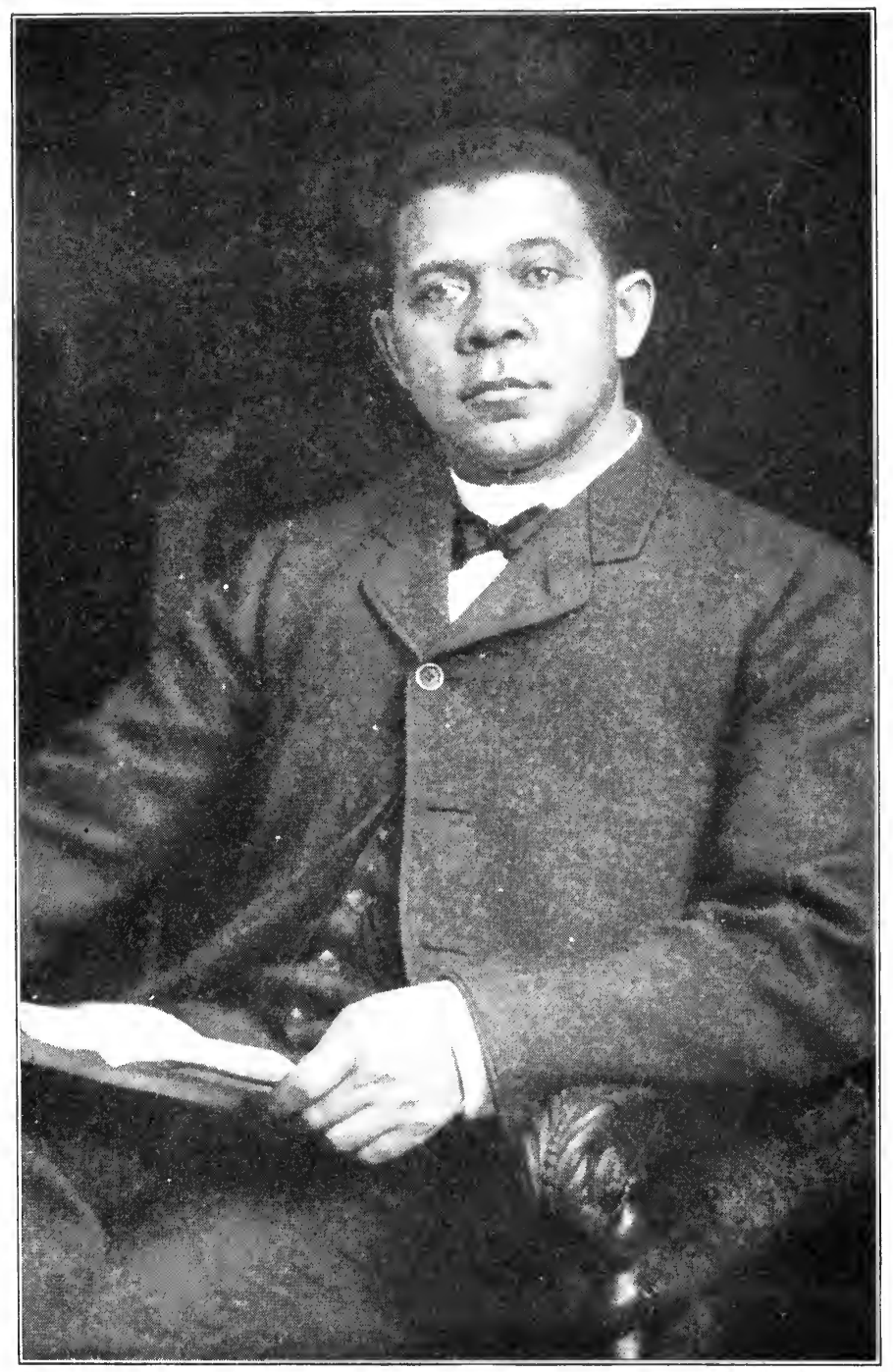

BOOKER T. WASHINGTON IN MIDULE LIFE 

sentiment, made bold to speak openly in his behalf. This was not without incurring much disapprobation, but the advocates had the manhood to take counsel of their own consciences, and were indifferent to aught else. The most notable instance of this kind was when a leading educator and bishop of the Methodist Episcopal Church, South, Bishop Atticus Haygood, became, not vehemently, but decisively, a pronounced advocate of the consideration due the Negro, and boldly published in the early eighties, "The Brother in Black." The moral heroism of his conduct was the more conspicuous because this was done at a time when race opposition was fiercest in the South. Not a whit less pronounced was Bishop Galloway, some time contemporaneous with Bishop Haygood, who lived a number of years after the decease of the former to continue the espousal of the cause of the Negro. Expressions like these, and from such sources, completely nullified those of the crazed penny bookmakers and cheap actors whose highly-colored sensationalism had a motive no higher than that of a plethoric purse.

But still a concrete demonstration was needed of that which had been insisted on by others for years, and that came when Washington appeared on the scene in the fullness of time and duly revealed that which the Negro is, and the possibilities resident within him. The conditions which had preceded, united with those that then were, gave an impulse to the cause of the black man that is incalculable. In a sense the country was not unprepared for the demonstration when it came to be made. 


\section{LIFE OF BOOKER T. WASHINGTON}

The way being open to Washington, keener vigilance was kept on him than ever before. Every utterance was weighed, every action watched, to see what a Negro would do with privileges so great. But his friends, who were multiplying among the most elevated of the whites of the South, lost no opportunity to show their confidence and esteem. A few years after the delivery of the Atlanta address, Dr. Washington had occasion to go to California via Houston, Texas; the business men of that city made a special effort to induce him to stop over and deliver an address at that point. His engagements being previously made forbade an arrangement of the kind, but he consented to stop over between trains and make an informal talk. On his arrival, he met with the leading business men of the city in a large office, where perhaps fifty of the picked citizens of Houston were ready to hear him. He was accorded a greeting worthy of any distinguished visitor, and though it was in the midst of the busy season, they had come to hear the noted reconciler and race-lifter, and for more than an hour many of those present stood while he spoke. This was only an incident, but it meant much in a large, busy city like Houston. The present writer heard him on that occasion and was surprised at the reception and responsiveness accorded him. He spoke with bold but courteous frankness in the presentation of the claims of his people, not without an occasional bold sally, and never in a subservient or apologetic way, but throughout with directness and respect, and no one could have had more attention and considera- 
tion. He made a profound impression, and at the close of his talk was applauded and each one present gladly approached him with the outstretched hand of congratulation.

On one occasion while uttering a stirring period in an address before an audience of both races, he recited the wrongs heaped on his people, trampling them down under the feet of force, and it seemed for a time that he was trenching on the ground of incendiarism. Finally he rose to his full height and asked in stentorian tones, "What are we to do? Are we to turn in vengeance, and pillage and burn, and return hate for hate? Not so. I will permit no enemy to degrade my soul to the level of hate. I shall endure, and so advise my people to be patient, for the day of deliverance will come." Expressions like these were eagerly caught up by his enemies within his own race and sought to be exploited as indications of the surrender of the race to all conditions whatsoever. For Washington to have adopted the policy desired to be pursued by his opposers in his own race, would have been to destroy himself and to have arrested the progress of his race for many years to come. En-) durance is not a servile quality, but sycophancy is. No one ever knew of Washington's indorsement of imposition on his people. By reason of his attitude of endurance he was in a better position to plead for that which was right. His voice was always heard in protest. He could at any time have inflamed his people with a word, and at any moment have precipitated slaughter and blood. But if he had done so, what 


\section{LIFE OF BOOKER T. WASHINGTON}

would have been the result? His race would have been crushed, and the possibility of an upward move would have been delayed indefinitely. His voice was always raised for endurance under wrong, for patience in tribulation, and for persistence in right living, as the sure antidote for persecution, and he believed that in due time all cruelties would be cured by a course like this.

History is not without a parallel to the condition of the Negro in America. At a certain period in English history, the Jew was the victim of as cruel persecution as was ever visited on any inoffensive and dependable people. Their synagogues, homes, and places of business were burned, and themselves were hanged, quartered, and otherwise mangled. They were oppressed by cruel taxation during the reigns of several kings, till at last under Edward I they were expelled with confiscation of their property; many of them were drowned, and such as were spared to live were stranded on barren shores with expressions of mockery and jeer. For fully three hundred years not a Jew was permitted to set foot on English soil, but under Cromwell they came slowly back. The laws against them were finally annulled, the Hebrews came to their own in the realm, many of them becoming eminent in the politics of the nation, one rising to the premiership of Great Britain while others became distinguished jurists. The present Lord Chief Justice, Sir Rufus Isaacs, or Lord Reading, is a Jew, while capitalists among them are manifold. The Jew to-day holds the purse-strings of Europe. Persecution is its 
own avenger. Unless history teaches this important lesson, then as an instructor it is useless.

- Until recent years, not only was the Negro not heard in his appeals against wholesale indiscrimination, but a white friend was placed under the ban if he should essay to interpose by a statement of fact. It is not least among the favorable signs of the times that that which has long been discussed as the race question, is at last beginning to be approached in a temper fairly free from partisan bias. Yet, despite the lapse of more than a half-century, the embers of the great conflict in which slavery perished are still hot, if one but deeply stir the ashes.

That which took place in connection with the Jews in Britain occurred in the thirteenth century in a monarchy not yet sufficiently removed from the period of barbarism to have given expectation of much else. But this is the twentieth century, and this is democratic America, the conditions in which evoked from an Englishman, some years ago, a parody on a familiar line, "The land of the free, and the home of the slave."

Certainly nobody would seek to idolize the Negro, nor even to accord to him that beyond his desert; but to the extent that he is worthy, every consideration of humanity, justice, and righteousness demands that recognition be given him. He asks no more-he could not ask less.

In the rôle he had assumed, Washington would avoid friction. He saw no possible good in even the slightest display of violence. He counseled peace as the 


\section{LIFE OF BOOKER T. WASHINGTON}

only possible means whereby the colored race could accomplish anything. He urged that when reviled his people revile not again. There was hope in submission to cruelty, none whatever in resisting it. $\mathrm{He}$ would "seek peace and pursue it." So far from seeking to absorb within himself whatever benefit might accrue from a course like this, Washington was constantly pressing the claims of his race. His people were being disfranchised in one state after another, including Alabama, his own state, but he was helpless. He still urged submission to the inevitable, insisting that by the limitations imposed as a standard for Negro qualification for voting, the colored man would be stimulated to fresher exertion, and that, in the long run, he would be the beneficiary. This failed to satisfy some of his own people, who insisted that his attitude was one of indifference to the good of the race, and that he was bought by the money of the white men in the promotion of his cherished interests at Tuskegee. While he knew that this was unfounded and therefore unjust, he was calm in the assurance of doing his full duty as he knew it, and would not deign to make reply. This accusation was, however, quite limited, while the masses of his people were with him.

Instead of resistance he would have his people neither pine nor whine, but with uplifted vision to higher things, press on in the way of industry and peace, and finally win by worth. This he continued to inculcate at Tuskegee, and on occasions before the public. In addressing his own race, he urged this, while at the same time he lost no opportunity to indi- 


\section{INFLUENCE AND POWER}

cate to the white race the importance of recognizing the fact that the good of one people was that of the other, and that the interests of the races were so identical that they must stand or fall together. With equal force he insisted that to keep the Negro depressed the white man must depress the standard of his own manhood, using the apt but homely figure which became a proverb- "In order to keep the colored man down in the ditch the white man must be there also."

From all this it is clear that Washington, more than any other man of either race, was laboring for the welfare of the Negro. More than any man of either race, perhaps, he saw the philosophy of the situation. It is true that his growth of popularity and of prominence gave him enlarged opportunity, and he was seeking to turn it to the best account possible. That the vision which he had was the sanest one possible, events have proved, and from the present trend of conditions the possibilities which he foresaw many years ago are gradually coming about. Severely criticised as he was he budged not an inch from his position, while he was equally steadfast in the provision of methods for race advancement. The many-sidedness of his character was brought out by the unusual conditions in which he was placed. Looked at from the distance of years, his work under the strain to which he was subjected is even more wonderful than it then appeared to be.

Booker $\mathrm{T}$. Washington combined in a potent way qualities which no other of either race displayed, at the time that he was laboring and planning for better 


\section{LIFE OF BOOKER T. WASHINGTON}

things. It was not extravagant to say that he was at once a seer, prophet, practical philosopher, sage, constructionist, race-builder, wise counselor, and a citizen of unimpeachable character, and as such, and because of the possession of these qualities, he made for himself a name in the annals not only of America, but in those of the most advanced civilization of the globe. It is easy to punctuate his record with " ifs," " buts," and "unlesses" and other terms equally disparaging, but his record is secure. He lived and wrought phenomenally and his name and fame are co-existent with modern civilization. 


\section{XVIII}

\section{RACE ORGANIZATION AND CONSTRUC- TION}

D R. WASHINGTON'S work at Tuskegee being now fully established and thoroughly manned, he was able to give more attention to the general interests of the race. Up to this time, that which he had done for his people in a general way, had been incidental and occasional. Of course, the school at Tuskegee was his first care, but he had constructed this solidly through the years. Capitalists and philanthropists, seeing its wonderful success, had become its cordial supporters. It is an error, however, to suppose that these resources came in copious profusion without solicitation. Every dollar invested at Tuskegee represented labor to procure it-the labor of the wise master-builder of the school. Not till he had shown his ability to construct, organize, and direct, was aid forthcoming. The financial assistance was the effect and not the means of his marvelous success. He had created something out of nothing, had built solidly and symmetrically at each succeeding stage of his laborious advancement, had wrought and achieved without flourish, and had displayed an ability so manysided that he had occasioned a condition eliciting the attention of philanthropists, in consequence of which 


\section{LIFE OF BOOKER T. WASHINGTON}

money came, as well as the timely counsel of able capitalists. Tuskegee came to afford an opportunity for investment in character that is rarely equaled. What more could be desired as an object worthy of aid than an institution that had been literally forced into existence in response to a necessity growing out of the conditions of ten million people who had but lately been slaves? Through years of difficulty it had forced its way, opposed by every possible obstruction, and had become famous by reason of its unprecedented and novel success. It was next to the seemingly impossible that had been wrought by Booker $\mathrm{T}$. Washington. He had upset every adverse theory indulged in concerning his race while it was yet struggling, and as its champion and leader he had shown that which the Negro is capable of becoming and of doing.

Tuskegee had thus become a great race fulcrum. That fulcrum constructed, Washington could now turn his. attention and administrative skill toward measures looking to race elevation. Here was even a greater task, vast and herculean in its proportions, but the principles so successfully applied at Tuskegee would now be applied as far as was practicable to the needs of a great race. Stupendous difficulties disputed his way at the outset, but the race must grapple with these and thereby establish its worthiness. They must be met by the black man in order to vindicate his claim to a place in American life. Could it be done? Tuskegee was the inspiring answer.

Washington never assumed that he embodied within himself the forces of the race, but just the contrary. 
He knew his people, knew their spirit and their possibilities, and knew how to touch keys that would evoke response. Familiar with the principles which had yielded success at Tuskegee, he sought to apply them as far as practicable to the race as a whole. One advantage was his-he had already in an incidental way aided in different directions these same people, had thus far succeeded, and he could point continually to Tuskegee as an object-lesson of that which all could achieve, at least to some extent.

Another advantage was his-the Negro had already shown by the most unmistakable signs that he was willing to do, was wishing to become worthy, and was longing for relief, but had been working blindly. His efforts had been incoherent. He could produce, but he was not an economical husbandman of the results of his labors. He was too much of a spendthrift of his precious dollars. He needed stern instruction, guidance, direction. He had been striking in the dark. His forces were dissipated, and his lack of knowledge made him the easy victim of the designing and the unscrupulous. He produced, but did not realize. Others realized the results of his labors. He must be trained to economy. There were unquestioned indications of vast ability on the part of the race, but that ability needed to be diverted into proper channels.

Some things that produced merriment at the expense of the race were in themselves indexes of deep worth if they could be properly manipulated. The Negro had great ambition-that germ from which all 


\section{LIFE OF BOOKER T. WASHINGTON}

growth of nobleness proceeds. As a mass he pined for something, he scarcely knew what. His struggle for education under every phase of disadvantage, suffering, and endurance was intense. His desire for a home of his own, churches, and schools, and places of business, was an indication of profound racial worth. Even his fondness for titles for which he was not worthy or prepared, though esteemed a weakness, and laughed at, had within itself a dynamic force that meant much. So far as was possible, he had shown his worth. The advance guard of his destined progress in the various vocations was already on the march. He had his pioneer poet of unquestioned ability in Dunbar, his novelist of force and beauty in Chestnutt, his painter of international distinction in Tanner, his scholars in men like Du Bois and Miller, his successful planters many, at the head of the profession of which was Grooves, his brilliant editors like Fortune and Trotter, his ecclesiastical leaders like Tanner, Turner, Morris, and others, his capitalists like Boyd and Pettiford, his jurists like Terrell and Lewis, his statesmen like Bruce, his orators like Walker and Mason, all of whom had pushed their way through difficulty and had attained to eminence in their respective orbits. Nor were all of these of mixed blood, to which fact of Anglo-Saxon re-enforcement is so often attributed Negro success, for some were as black as any. What did the race need in order to multiply these manifold? Nothing more than a fair chance in the race of life. Oppressed, suppressed, depressed, discouraged rather than animated, 
it needed the force of organization by means of which it could make itself so emphatically felt that recognition of merit could not be withheld.

To this end Washington now gave much attention without in the least releasing his grip on the school at Tuskegee. If the dominant public declined to accord recognition to the merit of these worthy people by the ordinary laws of recognition, then the Negro must prove by extraordinary fact that he was an element of undeniable value as an asset of American civilization. If the fact of his worth was that which was demanded, and if the unquestioned evidence of so many worthies was interpreted to mean only partial exceptions while the race was still regarded with serious doubt, then the Negro must rise in his gigantic race strength, and evince such worth that recognition could not be withheld. It was hard that this was so, very hard, but such was the logic of the situation.

The imported man from Europe and from Asia could come across the seas, become naturalized, and be invested with all the functions of American citizenship; but then they were not Negroes, a thing that meant much to many people. Here were millions of native Americans whose loyalty had not slackened through centuries, and whose capability had been phenomenally demonstrated where even the slightest chance was given-but then they were Negroes! Strangely blind as were many to all else than the fact of race, the opportunity of the Negro was narrowly restricted and largely to that of his own creation.

Very well, then, the race must meet the situation. 


\section{LIFE OF BOOKER T. WASHINGTON}

It could not afford to curse the situation, foment agitation and strife, and thereby make worse the conditions. There was a way out, and that way Washington took, followed by thousands of enthusiastic coadjutors. While regarded with a sneer by not a few, the efforts of the American Negro afford one of the most pathetic displays of human struggle the world has ever known. One has only to discard from his thought the race idea to appreciate the seriousness of the inner meaning of this struggle. At the first, Washington himself had been distrusted, and thought of by some as only a race-ruiner; but now that he had succeeded and had won the heights, he was applauded. Every Negro could not become a Washington, but every one, in proportion to ability, could do something, and in the aggregation of these into organization, a serried front of merit could be shown that none could gainsay. It was this which this great leader now sought.

He would lay under tribute every means of encouragement. He would write a timely book, a revelation to both races, in which he would show his own struggles from the period of a pauperized youth fresh from slavery, all along up the slippery heights that he had scaled. Hence his " Up from Slavery." $\mathrm{He}$ would follow this with yet another which would be a source of inspiration and of stimulation; hence "The Negro in Business," itself a revelation to his own people and to others besides. By word of mouth and by busy pen and constant trips and tours, he was infusing fresh life into his people everywhere by means 
of facts and principles which were a source of astonishment alike to both races.

There was that in his course of procedure at this time which, had he been other than a Negro, would have been ranked as the highest exhibition of magnanimity, which it was; but being a Negro, many esteemed it no more than a display of servility and of sycophancy for purposes purely sinister. The spirit which dwelt in Washington's course was that of a common Americanism, not one of isolated and defiant racialism. He encouraged no such spirit as that of defiance, of assumption, or of presumption, but he would weld into compactness a common American sentiment, a democratic unanimity of coöperation on the part of both races living in a common country, under a common fundamental law, and under a common flag, with a common goal to be reached. While a great race-lover, he was a greater man-lover. $\mathrm{He}$ would smooth down the asperities of both peoples alike, and bring them into common union of effort, each in its own sphere, distinct in race, one in purpose.

Exceedingly valuable to his own race, Washington was not a whit less so to the Anglo-Saxon. He was a common benefactor, and the dominant race will be recreant to the simplest principle of gratitude if there be withheld the appraisal due him as a great man whose entire force was spent in genuine patriotism for the good of all alike. At the time about which we now write, he was in the performance of his most delicate mission, and was sometimes gratuitously misjudged 


\section{LIFE OF BOOKER T. WASHINGTON}

and his conduct forced into a meaning which was the opposite of what it really was. This was illustrated at different times of which he was not aware, and an instance is here recorded as an index of others.

He was traveling on a Pullman, with his wife, from Montgomery to New Orleans. A white gentleman who knew him was passing along the aisle and he stopped and shook hands with him. Another, observing the hand-shaking, followed the gentleman into the smoking-room, with the impertinent question: "Was that not a nigger with whom you shook hands, just now?" $\mathrm{He}$ was told that it was, and that the one with whom he had thus spoken was Booker T. Washington. This led to a tirade on the part of the interferer, a rain of abuse of Washington with an interlarding of oaths, concluding with the expression of the opinion that both Washington and his wife should be expelled from the sleeper. A number of gentlemen overheard the remarks, and a manly defense of Washington was made by every other, not without the expenditure of much passion. The chief and unanswerable thought was advanced that the demand was made on the Negro to become somebody, and that when he sought to do this, he was denounced. He was railed on when he did not dance at the piping of others, and there was mourning when he would not lament. Finally the objector fell back on the defense, "Yes, but Booker Washington is a nigger!" Here again, he was not permitted to make a stand, but his inconsistency was made so clear that he was utterly routed, and sought to turn the occasion into a joke, 
to the disgust of all present. Booker $\mathrm{T}$. Washington had reached a period in his life when there were many who would befriend him in any circle, and as a representative of his race his people shared in the growing sentiment in the South. He was still achieving, still pursuing.

One other occasion may be mentioned in the same connection. A gentleman from the South had been visiting Tuskegee, where he became overwhelmingly impressed by the school and its work; wishing to ascertain the estimate in which the institution was held in the locality, he engaged in conversation on the train with a prominent citizen of Tuskegee, a judge, whose premises abutted on those of the campus of the Institute. Feigning sincerity the visitor quizzed the judge by asking how it was possible for the people of Tuskegee to tolerate the presence of so many young Negroes, and of a herd of teachers of that race under such a man as Booker Washington.

The judge, taking the questioner seriously, replied that no doubt many who lived away from Tuskegee entertained thoughts like those, but added that his yard adjoined the campus, and he presumed that if anyone was able to express an opinion of the school he was. Then he said he had been living there for years, and that he regarded the presence of those people as a genuine protection to his home. He explained that he was often away from home for days together, and felt the securer because the school was there. He said that those people in the school would die for his family if necessary, and that so far from 


\section{LIFE OF BOOKER T. WASHINGTON}

being a menace they were a protection and a blessing. Then at great length he proceeded to tell of the utmost order preserved, the absence even of yelling on the grounds, the politeness always shown by the humblest student, the aid of those valuable people to the town, the service that they rendered with so much cheerfulness, the excellent butter and milk, vegetables and fruits that they furnished, the readiness and skill with which they executed any work desired, and concluded by saying that the school was the pride of the town. Still insistent in his assumed sincerity, the questioner remarked, "But they are Negroes." This led the judge to remark with decided emphasis that it made no difference if they were, they met the demands of first-class neighbors, and that should be sufficient to satisfy any reasonable man. Proceeding still farther he remarked that there was a marked disposition on the part of some to underestimate the Negro, but if the visitor would stay sufficiently long about Tuskegee he would be thoroughly converted. The questioner thereupon expressed ample satisfaction, and the conversation was turned.

One of the direct methods of race organization and construction was the suggestion to a number of his brightest students to found schools in the midst of the densest populations of the colored race in different parts of the South. These miniature Tuskegees were indirectly fostered by Dr. Washington, land being procured in each instance through the enlistment of influential white citizens, and, in due time, adequate buildings erected. 
The most far-reaching work in race enlistment, however, was that of the organization of the National Negro Business League, the first session being held at Boston in 900 . This organization cohered the Negro forces of the nation as nothing else has done. Year after year it has brought together the active, economic forces of the race, and has imparted a stimulus that has more thrilled the colored race than has any other movement. An annual session of the general body is held in some city, North or South, at which times Negro business men vie with each other in exhibiting their varied enterprises of whatever kind. For fifteen years these annual sessions have now been held with a wonderful increase of interest and enterprise. The master spirit of Washington has dominated its councils and proceedings, he having been chosen the presiding officer at each annual session till his death.

What are some of the visible results of this organization? There are twelve auxiliary state leagues maintained in each of the following states: Alabama, Arkansas, Florida, Indiana, Kansas, Louisiana, Mississippi, North Carolina, Oklahoma, South Carolina, Texas, and Virginia. In each of the states named and in others there are chartered local leagues as follows: Alabama, I8; Arkansas, 3; California, 5; Colorado, 2; Connecticut, 2; Delaware, I ; District of Columbia, I ; Florida, Io; Georgia, I6; Illinois, 6; Indiana, 4; Kansas, 9; Kentucky, I3; Louisiana, 9; Maryland, 6; Massachusetts, 3; Mississippi, I I ; Missouri, 5; Nebraska, I; New Jersey, 6; New York, 3; 


\section{LIFE OF BOOKER T. WASHINGTON}

North Carolina, 23; Ohio, 4; Oklahoma, I6; Pennsylvania, 4; Rhode Island, 2; South Carolina, II; Tennessee, 15; Texas, 21; Virginia, I8; West Virginia, 8, and Africa, I. This makes a grand total of 257 local leagues, every one of which is a busy hive of activity and enthusiasm. Here we have as the product of this wizard of quiet organization a long chain of local business centers of inspiration and force in race construction.

Nor are these merely nominal organizations. They are instinct with vitality. To attend their meetings, especially those of the largest, or national, organization, gives an idea of the rapid development of the race such as cannot be elsewhere had. The welldressed men of business are not present for verbose prattle, but are calm and dignified, and in their brief speeches are short and sharp, with the due regard for economy of time so characteristic of men of business.

According to the census of I9ro the Negroes owned 218,972 farms embracing almost 20,000,000 acres, owned or presided over by 600,000 colored men, and had built and equipped about 500,000 homes, while they had 38,000 churches, 22,000 business interests, and 53 banks. The total valuation of the property owned by the Negroes of the country amounts to about $\$ 800,000,000$. It is altogether worthy of mention that Negroes sustain about 200 private schools and colleges, besides hospitals, old folks' homes, and sanitaria. The conditions of the race in the different states of the South are in proportion to the extent of coopperation between the two 
races. While there are perplexing features of that which is popularly called the race question, there is no doubt about the continued rapid progress of the Negro.

As the years went by, the labors and travels of Dr. Washington were greatly increased. $\mathrm{He}$ was subjected to a strain which itself became normal so habituated was he to it. He was in perpetual demand here, there, and everywhere, and honored everywhere for his works' sake. Several years before his death he had an appointment to deliver an address at Charlotte, North Carolina, and no pains were spared to show him every possible distinction. A committee of prominent white citizens were appointed by the mayor to meet him at the station and accord to him a reception worthy of his position. These white citizens of the South had nothing to gain by flattering the great pioneer of Negro elevation, therefore their actions could not have been other than sincere. It may be said in passing, that in no other state of the Union is the colored race more advanced than in North Carolina.

This and other incidents in the career of Dr. Washington and, indeed, in that of other colored men of worth, proved to him and to them that a reformation looking to race adjustment is on the march in the South. Expressions like the one just mentioned bore positive proof to the mind of the illustrious uplifter that his labors were not in vain. In summing up the estimate of his worth nothing is clearer than that he did more for his people during his career than all others of the race combined, and did it in such way as 


\section{LIFE OF BOOKER T. WASHINGTON}

to win the approbation of the humanitarians of the world.

Not till twenty years before he passed away was Washington enabled to catch in public address the ear of the South, but thenceforward no one of the South engaged more the attention of the public. If he stooped to conquer, the people, irrespective of race, were the beneficiaries, and he passed to his tomb followed by a universal acclaim that a great man was gone. 


\section{XIX}

\section{THE SPIRIT OF ENLISTMENT}

T $T$ required nearly twenty-five years of gigantic grapple with difficulty for Booker $\mathrm{T}$. Washington to bring his race in America to the attention of the world. In obscure regions here and there about the South, entirely unobserved save in the localities in which they were, many colored men had gradually come into the possession of land cheapened in value as the result of the war, had gone to work, and were quietly and obscurely accumulating wealth, while others had established little industries of various kinds, these formed a nucleus of organization which became an engine of propulsion to the pioneers of race advancement, and stirred others from their lethargy. These forces were working without concert of action, and unknown to each other, because they had no means of intercommunication, and it was this that Washington supplied at a time when public sentiment had become more conciliatory. By the combination of these two agencies of organization and conciliation the race was enabled to set forth on a new era.

Being able to exploit the achievements of his people under difficulty, he deepened sympathy into substantial aid, and the first line of racial barriers went 


\section{LIFE OF BOOKER T. WASHINGTON}

down. Not till then was he able to enlist the substantial help so greatly needed. Tuskegee had become a common point of distribution of Negro force and influence. Its graduates were demonstrating in trades, agriculture, professions, schools, and in much else, that for which the school stood, and these agencies combined with the numerous voluntary strides made in different regions furnished a basis not alone for race elevation, but for an appeal of enlistment of those who could do so, to aid in the work of uplifting.

It is an error to think that men and women of wealth fanatically and surreptitiously poured their money out to Washington in order to contribute to the school of a race so long in bondage, coupled with the purpose of rebuking the South by the elevation of the Negro. Such a conclusion is not only most illogical, but is entirely foreign to the motives of benefactors in the North, every dollar of whose gifts was a means of relief to the entire South, and worthy of the highest appreciation. The contributions made to Tuskegee were in no wise more helpful to one race than to the other. Time will vindicate not only these, but the outlay of such great organizations as the American Baptist Missionary Society, the American Missionary Association, and other great religious bodies that were early on the field as the contributors to a needed civilization. This is the spirit with which the most enlightened and unbiased sentiment of the South regards these benefactions, and views to the contrary are exceptional alike in character and in number. 
As the clearness of the motive of Dr. Washington became increasingly transparent with the evolution and practical demonstration of his plans, means came, but not without continued strain of effort on his part. To those without, it meant much when Dr. Washington had succeeded in winning the approbation of the people of the South. Not till he had established a substantial footing was he able to obtain a hearing at the tribunal of public opinion. He alone demonstrated the only method of effecting race adjustment. Nor did he, by any means, accomplish all that needs yet to be done, but he did succeed in dissolving the advanced lines of difficulty, without which nothing was possible. His individual wisdom and success brought the means of success in a way praised by all.

Those whom Washington drew to his support were not men of hasty and unwise action, nor of a type to be merely sentimentally affected. They were stern business men. The investment made in character at Tuskegee and elsewhere was one as seriously and considerately made as if they were investing in stocks and bonds. Their investments were for returns, the prospect of which must be visible in dividends of character and of life, else not a penny would have been contributed. Investments like these, therefore, made by men like these, are a guarantee of the tremendous worth of the enterprise. Nor is it unbecoming or unreasonable to suggest and even to urge, in this connection, in view of the increasing wealth of the South and the increasing value to both races of 


\section{LIFE OF BOOKER T. WASHINGTON}

our worthy colored institutions of learning, that these merit the timely financial aid of many Southerners who can now assist. It is difficult to conceive of objects more worthy. This admits of application alike to the Tuskegee enterprise and to numerous other schools. With the increased standards of these schools there must come increased value of common weal.

Among the earliest philanthropists to recognize the worth of Tuskegee was Mr. A. H. Porter, of Brooklyn, New York, already named. Later came a host of other donors, some of whom, though liberal in the bestowment of gifts, withheld their names and insisted that that which they did should be privately applied without themselves being known. That which was subsequently given by many capitalists was judiciously withheld from undue publication, and the general result is known only in the continued expansion of the great school. Knowledge of the amounts given by men like Andrew Carnegie, John D. Rockefeller, Julius Rosenwald, and other generous givers is not a matter of serious concern. The important thing is the fact that men like these became seriously enlisted in the great work, and liberally aided in its support.

When Mr. Carnegie's attention was first called to the work, he failed to see sufficient in it to enlist him, and not unlike many others, withheld his gifts till Washington should be able to demonstrate that his enterprise was worthy of substantial help. Declining in 1890 to contribute to the school, it had within the next ten years so progressed that $\mathrm{Dr}$, Washington wrote the following letter: 
Tuskegee, Alabama, December 15, 1900. Mr. Andrew Carnegie, 5 West Fifty-first Street, New York.

DEAR SIR:-Complying with the request which you made of me when I saw you at your residence a few days ago, I now submit in writing an appeal for a library building for our institution.

We have I, IOO students, 86 officers and instructors, together with their families, and about 200 colored people living near the school, all of whom would make use of the library building.

We have over I 2,000 books, periodicals, etc., gifts from our friends, but we have no suitable place for them, and we have no suitable reading-room.

Our graduates go to work in every section of the South, and whatever knowledge might be obtained in the library would serve to assist in the elevation of the whole Negro race.

Such a building as we need could be erected for about $\$ 20,000$. All of the work for the building, such as brickmaking, brick-masonry, carpentry, blacksmithing, etc., would be done by the students. The money which you would give would not only supply the building, but the erection of the building would give a large number of students an opportunity to learn the building trades, and the students would use the money paid to them to keep themselves in school. I do not believe that a similar amount of money often could be made to go so far in uplifting a whole race.

If you wish further information I shall be glad to furnish it.

Yours truly,

Booker T. Washington, Principal.

In response to this came the following reply:

"I will be very glad to pay the bills for the library building as they are incurred, to the extent of twenty thousand dollars, and I am glad of this opportunity to show the interest I have in your noble work." 


\section{LIFE OF BOOKER T. WASHINGTON}

While generous gifts occasionally came, the bulk of the basis of support for the Tuskegee Normal and Industrial Institute came from innumerable small donations derived from as many sources. This had the double meaning of wide popularization of the work and of much intense labor on the part of the indefatigable Principal. It is worthy of record that the graduates who went out from the school would annually remit from their slender incomes amounts ranging from twenty-five cents to ten dollars. Nor should the significant fact be overlooked that the legislature of Alabama, through the efforts of Hon. M. F. Foster, the leading representative of the county in which Tuskegee is located, increased the appropriation from $\$ 2,000$ to $\$ 3,000$, and afterward raised it to $\$ 4,500$. Generous aid was also given from the John F. Slater Fund, of which Dr. J. L. M. Curry, an Alabamian, and a former member of the Confederate Congress, was the general agent. In the same connection should be named Mr. Morris K. Jesup, of New York, who as a capitalist became interested in the Tuskegee enterprise, and gave unstintingly of his means and his time and thought to the work. No friend of the enterprise has been more loyal and unremitting in his efforts than Hon. Seth Low, of New York, at present the chairman of the board of trustees of the Institute. It is of peculiar significance that two Presidents of the United States, Roosevelt and Taft, have given personal time and labor to the promotion of the same great interest. With increasing significance the interest of Southern men like Messrs. 
Belton Gilreath, of Birmingham, Alabama, and W. W. Campbell, of Tuskegee, has for years been zealously enlisted in the same worthy cause.

The object here is not so much to undertake to furnish a list of the host of friends and supporters of the great and growing school at Tuskegee, as to give an idea of the rapid increase of enlisted interest in its behalf. The interest of those and of hundreds of others that might be worthily named, was not that which was merely verbal and nominal, but that which meant labor and money often rendered, and cheerfully. The dawn was gradually brightening into the fuller day.

In view of the popular misconception of the ease with which the resources both of influence and of means came to Booker T. Washington, it is only fair to say that none of these was without the most unremitting labor on his part. The belief that his was a sphere of indolent ease and comfort is wide of the fact. As opportunities and advantages multiplied, whether locally at Tuskegee, or generally in his efforts in behalf of his race, his labor was correspondingly increased. Skill and facility were acquired by him as a result of the bitter experience of years, and these he was unremitting in turning to great account, not in one direction alone, but in many. The work which he daily did for years was enormous. Experience in the rapid management of detail brought him to the point where he could rapidly dispatch business, but it was never without draft on his resources of mind and nerve. Conceiving, planning, devising, directing, ad- 


\section{LIFE OF BOOKER T. WASHINGTON}

vising, by pen or correspondence, were always his. With the return of consciousness every morning from sleep, often restless from perplexing enigmas, his mind was confronted by huge tasks which he alone could perform. He had pressed the work of his life to the point where to stop meant not alone a standstill, but stagnation. He had a prodigious fund of physical strength acquired in his younger years, but even that was now being sapped under the strain to which he was subjected. The interests of millions were piled on him by the necessity of the situation, and, Atlaslike, he had all to bear. His peculiar lot afforded the spectacle of one silently toiling, thinking, planning, by day, by night, pressed by encompassing burdens which bore in from every quarter, and yet of one quietly and uncomplainingly enduring while he cheerfully labored on.

An erroneous view of Washington was that of a man who had shrewdly become famous by taking advantage of a peculiar situation, delivering an occasional public address, drinking in applause, writing now and then an article for a magazine, and reposing at ease either in a pleasant home at Tuskegee, or else lounging in a New York hotel. The truth is that he was a sorely pressed man, knowing nothing of ease or of release from intense labor, but vexed by problems of divers kinds of which the world knew nothing. He was eliciting, combining, and directing unceasingly. Possessed of a cheerful temperament and a spirit that was optimistic, these qualities were in constant conflict with the wear and tear of body and 
of mind. He never complained and seemed never to think that recuperation was necessary, and but for his systematic methods of work he would have sunk under the burden which he bore. The marvel is how he accomplished so much and did it so well. How one could find time to write books as he did, under a constant strain of keeping in advance of the necessary demands made on him, it is difficult to see. That which the public saw of him was the least of the features of his life.

His correspondence became prodigious. Whether in New York or at Tuskegee, he was daily inundated with letters, while at either end during his absence they would accumulate in vast heaps. Miscellaneous information was sought by members of both races, advice solicited by farmers, mechanics, bankers, merchants, and educators, and these always received respectful answers, and as promptly as possible, while he must at the same time be managing the affairs of his great school from which he received a detailed daily report during his absence. He must all along be mindful not only for the present needs of the school, but must make due provision for its advancement as it was constantly expanding. He had a corps of trained and efficient helpers, but their functions were circumscribed, since he must be responsible for the things said and done. By reason of the conditions of which he was the creator, with respect to the guidance of the complicated affairs of his people, who were themselves hindered and hampered, his immediate future was always filled with difficulties to be solved. 


\section{LIFE OF BOOKER T. WASHINGTON}

Besides all this, there were numerous minor questions that constantly came before him which needed prompt answers. At one time a musician of some pretension lingered about Tuskegee with a desire to render some musical performances, and eagerly sought to gain the consent of Dr. Washington to give an entertainment at the Institute, but the permission was kindly but firmly withheld. Because of his failure, he published a booklet in which he proposed to make certain exposures of the conduct of the faculty and students of the institution, which was described as viciously immoral, while he sought to inflame race passion by the strongest appeals possible. He gave as wide circulation to his little bcok as possible, but it fell still-born. In no way was attention given it by Dr. Washington or any other, and its failure was complete. Washington's invariable habit was to give no heed to rumors or rejorts, and he would never mention them unless asked about them by a friend.

In his perpetual labors he had to do with the lowliest as well as with the leaders of the races; he had to deal with both races as an advocate for the things due his people, and his position was often a delicate one. $\mathrm{He}$ had also to do with both sections, South and North, and that he should have been able in the most turbulent period of our national history, so effectually to escape blundering, was exceedingly creditable to his wisdom. That, again, he should have so thoroughly won the confidence of all classes, save that of the invidious, is most astonishing. All efforts made to thwart him were futile. He established a reputa- 
tion for integrity that made him practically invulnerable to the assaults of his enemies, and in his long career succeeded in enlisting the best people of the land in his behalf personally, and in behalf of the great cause which he fostered.

Exceedingly desirous for the elevation of his people, he pleaded for patience and consideration and was intent on proving that the Negro is

“.... as much a man

As moves the throng among; As much a part of the great plan With which creation's dawn began As any of the throng."

He sought unceasingly to make a place for his people in American life. For the Negro to be always dependable on another race would make him despicable. Honorable industry would lead to independence. Industrial ability would make the race an indispensable adjunct to our civilization, and this he impressed on all his race organizations, while he sought to turn his people away from the fancied idea of bounding upward by a single leap to the highest rung of the ladder. The South was gradually returning to its own under new conditions, and he would have the colored race become one of the chief factors in the progress made, and thereby become established on a basis the worth of which could not be questioned. In other words, he wished his race to be identified with the rehabilitation of the South, that the Negro might ever afterward become an important part of the section. 


\section{LIFE OF BOOKER T. WASHINGTON}

To him it was a golden opportunity for the Negro race, and one that it could not afford to slight.

As he viewed it, the Negro could thus establish for all time a base of worth whence could be drawn supplies. In a sphere like this the Negro was without competition. Should he fail, the foreigner would be imported, and the Negro would be jostled aside in his helplessness. The colored man could be educated, and should be, but alongside his mental training he would have him an industrial factor; for, as he reasoned, what use would he have for an education entirely classical, or literary, if he had only this? Washington would have the Negro possessed of a force indispensable and always in demand. This would make him independent, while without it, he would be the most dependent of men, no matter what his mental equipment might be. If there were denials of the rights of the colored race, of justice, protection, security of property, and political privileges, even while this was being demonstrated, what would be the condition of the man of color if his ability was confined to his mind? On the other hand, as the worth of the race came more and more to be recognized, there would come about consideration and good-will, respect and neighborliness, and an identity of interest of both races, that would enable the colored man to win in the long run. So thoroughly was he possessed of this idea that he declined to abandon it to the close of his life. Others of his race did not acquiesce in this view, and insisted that it placed the Negro in a menial attitude; but while he had a practical demonstration of 


\section{THE SPIRIT OF ENLISTMENT 267}

his view, there was left to others no more than theory. In the upward movement of the race, despite the obstructions which still in part remain, the public must decide how nearly his conception has been equaled, and how far his course and counsel have been vindicated. 


\section{$\mathrm{XX}$ \\ TO EUROPE}

TOR eighteen years Dr. Washington had been under constant strain. He was possessed of a virile constitution, and his toughness of fiber and equableness of temperament had served to sustain him through the tension of years. $\mathrm{He}$ never mentioned resting, because it seems not to have occurred to him that it was his duty to recuperate. He was so fastened in a combination of circumstances that every waking hour had its appointed task. Not only did he not find time for repose or recuperation of his vital forces, but the process of his labor afforded promise of increased taxation of strength as new demands were constantly arising along the path of his projected plans. His friends observed that he was yielding to the incessant burdens which he uncomplainingly bore, and began to devise means for his relief. To himself there was no end of the tasks that were accumulating constantly. With increasing gait he had been going the round of the treadmill for years together.

His normal condition had become one of fatigue, of the gravity of which he was not aware. His friends had noticed a languor in his eye, a forlornness of expression, and a disposition to preserve a quietness 
in company, whereas before he had been quick of speech and alert in action. He was evidently a very tired man, but buoyed by a prospect of advancement at all times, the fact had escaped his detection.

By preconcerted action on the part of a number of his friends in Boston, he was invited to that city, in the early part of 1899 , to attend a meeting, the ostensible purpose of which was that of raising funds for his cherished school at Tuskegee. It was well known that the announcement of a purpose like that would lure him to Boston, and this was the plan hit upon to induce him to go. An attractive program was arranged, two other colored men of note were to speak, and the meeting was to be presided over by Bishop William Lawrence, of Massachusetts. He was assured that the meeting would mean much for Tuskegee, and no matter what the nature of his engagements was, he must shape his plans to be present and to speak. The other colored men to be present were the poet, Dunbar, who was to read some of his selections, and Professor W. E. B. Du Bois, both of whom were to be followed by Professor Washington, whose address was to be the chief feature of the occasion.

A meeting so unexpected to Washington, and so gratifying, withal, he promptly agreed to attend. He husbanded his strength to the utmost, as he felt how much depended on a meeting involving so much for the school. There was an evident effort on his part to appear at his best in his speech, which was well received and gratifyingly responded to financially, but he was much exhausted when it was over. He was 


\section{LIFE OF BOOKER T. WASHINGTON}

about to leave the hall and hasten back to Tuskegee, when he was accosted by some ladies and asked how he would like to take a trip to Europe. Presuming that this was simply a passing question, he merely remarked that it was one of the dreams of his life, but that he was too busy a man to hope that it would ever be realized.

He was then told that a liberal purse had been made up for him and Mrs. Washington, that they might go abroad the following summer, and that nothing was left but for him to consent. He explained that it would occasion so great a gap in his plans that while he was grateful for the offer, he could not see how he could possibly accept. He placed before them the enormous work that had to be done during the summer, stating that during that season he must raise the funds necessary for the next session. But he was told that all this had been considered, that every feature of his work was in contemplation, and all that was needed was his consent to go. This was indeed a relief as well as a great surprise, and after ascertaining how minute the plans of caring for his work were, he consented. He could now return to Tuskegee with a buoyant heart, to make preparation to sail in the early summer and thus obtain a much-needed rest. The session of the school over, he went to New York ready to sail at the appointed time. According to the original plan, his wife accompanied him, as she had shared with him his arduous work and care.

Until now practically nothing has been said about the home life of Dr. Washington. He had been a 
man not only of many burdens and cares, as we have abundantly seen, but a man of sorrow. He had lost two wives, and was now married to a third. Somewhat more than a year after going to Tuskegee, he was married to Miss Fannie N. Smith, of Malden, West Virginia. His wife was a graduate of Hampton, and a most valuable ally did she prove to him in his early struggles at Tuskegee. She died within two years after their marriage, and in 1885 he was married to Miss Olivia Davidson, who did so much to get the school on its feet. She was invaluable to him as a constant helper, and was the most successful solicitor of funds he had ever had. She died in 1889. In 1893 he was married to Miss Margaret J. Murray, who survives him. A graduate from Fisk University, she became first a teacher at Tuskegee, and, later, lady principal of the school, which position she was holding at the time of the marriage. It was she who was now to accompany him to Europe.

May Io, I899, found a large party at the pier at Hoboken, ready to sail on the Friesland, of the Red Star Line. Mr. Francis J. Garrison had assumed the task of making all the arrangements, the tickets were in hand, and the room provided. Numerous friends from New England and elsewhere had gone to New York to see the party off. Washington had never been on an ocean steamer. To him it was a novelty, and to his practical mind nothing was more interesting than to go over the steamer, learn all its parts and appointments, and study its system and method. But he found it difficult to rid his mind of care. He could not 


\section{LIFE OF BOOKER T. WASHINGTON}

help falling now and then into a pensive mood and wondering if, after all, it was the wisest thing to do. Might not a break come somewhere in his plans of work? Could others do as he would in certain contingencies? Might not his own people misunderstand the trip, and, to use a term of their own coining, regard him as "uppity"? Would it not have the effect of alienating his race somewhat from him? Still he felt that the cause was in hands as safe as his, and he could not long survive the strain to which he was now subjected unless he should unbend. So dismissing all misgivings he would surrender himself to rest, and get the most out of the opportunity. The conditions that greeted him on the steamer gave an earnest of the pleasure that awaited him. The crew was most cordial, the captain especially kind in his greeting, and the Southerners, of whom there were a number on board, were as cordial and polite as were any others. There was no reason why he should not have a pleasant voyage. He was already a new man. $\mathrm{He}$ felt the relief of the lifting of a world-burden.

The first morning after leaving New York, Dr. Washington felt an unusual sense of drowsiness. It was nature reasserting itself. $\mathrm{He}$ had so long been under intense tension that he was not aware but that that condition was a normal one. Now where care could not reach him, relieved of the pressure of daily drudgery, he could do nothing else than rest. Yielding to the suggestion of physical infirmity he slept, and averaged fifteen hours of sleep out of the twentyfour during the ten days' passage from New York to 
Antwerp. Till now he had not discovered how very tired he was. With the soothing thought that he had no cares, no callers, no letters to dictate that dayall was rest, and he slept.

Consequently when Antwerp was reached on May 20 , he was a new man. When he stepped off the steamer, he felt like an athlete. Then began diversion from the novelty of scenes such as he had never before witnessed. The peculiar customs of the Belgians, the gayly-dressed people in the park, whom he could watch from his window in the hotel, the milkwomen with their braces of dogs hitched to tiny carts on which were large, bright cans of milk, a single horse hitched to one side of a double wagon; men, women, and girls selling flowers, and making the air strident with their outcries, the go-easy saunter of the throngs along the streets, about the public places, and in the gardens and parks-all was a bright and animating scene of novelty.

After a day or so came a trip to Holland. The novelty of this trip lay in the fact that most of the way the party was to go on a canal-boat. The old boat moved sluggishly along the current, never the least in a hurry, and Washington was all agog to catch impressions. To his practical thoughts there was much in the fact that the Hollanders left not a foot of soil untilled. Down to the water's edge, in every nook and cranny, the earth was made to yield her increase. Always economical from necessity, here was a fresh lesson to the practical economist. The superior soil of the Netherlands, the bright green 


\section{LIFE OF BOOKER T. WASHINGTON}

pastures freckled over with the beautiful Holstein cattle, the sheep lazily grazing in the meadows and scarcely raising their heads to give a casual wooden stare at the boat, all suggested repose to the man from bustling America. Yet the suggestions made impressions of value to a practical mind. At Rotterdam with its peculiar shipping methods were yet other novelties, while at The Hague, where a peace session was being held, he was greeted by the distinguished American representatives who showed the pioneer race-uplifter of their country marked consideration.

Then came Belgium again, quiet old Brussels, with its manufactories of carpets and lace, its fine galleries of art, its spacious royal grounds, its historic associations, its peculiar architecture; and Waterloo, a dozen miles away, with its famous battlefield and its monument of stone surmounted with the lion holding in its uplifted paw a miniature globe, its once bloody ground now covered with the wheat fields of peace.

Thence to France, with its grain waving in vernal splendor, and finally to Paris, gay, thoughtless, and beautiful Paris, where he lingered for weeks a gazer at its beauties of art, and the recipient of many distinguished expressions. In Paris he met many distinguished Americans, among who was ex-President Harrison. General Horace Porter, American ambassador, and Archbishop Ireland were also there to share in the cordial greetings to the great Negro leader.

His appearance in the French capital became known, and he was invited to a banquet, as an honorary guest, at the University Club. In a speech at the 
banquet General Harrison made special allusion to the distinguished colored educator and his phenomenal achievements at Tuskegee, and amidst round on round of applause and greeting Washington responded. A circuit of social functions followed, and on the first Sunday after his arrival, Washington was invited to attend the American chapel, and address the audience with Generals Harrison and Porter.

Naturally, nothing in Paris so interested him as the famous American colored painter, Henry O. Tanner, a native of Philadelphia, whose paintings had been bought by the French government. When he advised certain white friends to see these artistic triumphs, he found it difficult to compel the belief that an American Negro was among the world's greatest artists, a fact to which France attested by buying his paintings purely on their merit as expressions of art. As he gazed with pride on these expressions of artistic beauty, he recalled the principle which he had inculcated from the beginning at Tuskegee-that anyone, no matter what his color be, will receive recognition and reward in proportion to performance. To do a thing better than any other is to forestall competition. When the French government was seeking the best on the market, the best was taken, and the others left. Tanner's proved to be the best, and no one stopped to ask the color of the painter. It was the painting that was sought, the highest expression of art, and as such Henry Tanner's were bought and hung on the historic walls of the Luxembourg Palace.

During the stay of several weeks in Paris, Wash- 


\section{$2 \% 6$ LIFE OF BOOKER T. WASHINGTON}

ington participated in several distinguished social functions, including a brilliant reception given by Ambassador Porter, who made a formal call on Washington to invite him to be present. Here he met Chief Justice Fuller, of the Supreme Court of the United States, and Mr. Justice Harlan, besides other eminent Americans.

Every phase of French life was a study to the great American Negro. The frivolity of Paris life, its golucky population, the utter lack of seriousness in the affairs of life, its splendid wealth and its poverty, its gorgeous palaces and its haunts of squalor, its ease and its misery, its museums of art and its shocking exhibitions of immorality, its nobles with time hanging heavily on their hands and its poor with their heavy burdens-life here with its extremes and inequalities took his thoughts constantly back to his own people in the distant American states. He was comparing the conditions about him in Paris with the growing buoyancy and hopefulness of his own people, and in his heart he decided he would rather be an American Negro than a Erenchman. His responsive and receptive mind was storing away lessons of value.

London came next-merry England-and then home, which he was beginning to long once more to see. London with its staid greatness and grandeur, its winding streets and capacious circuses where many streets converged, its ceaseless throb of energy, its places of historic renown, its records, its monuments and museums, its great libraries and hoary institutions, its perpetual yet placid flow of life, so different from 


\section{TO EUROPE}

effervescent Paris-what a great volume of study was old London!

The gifted and courtly Choate was the American minister to the Court of St. James, and he let pass no opportunity to make pleasant the stay of the representative of a great race. $\mathrm{He}$ arranged for Principal Washington to address a public meeting at Essex Hall, at which Mr. Choate presided. A vast concourse of Londoners eager with curiosity to see so distinguished a Negro, and to hear him speak, thronged the immense hall. The introduction by Mr. Choate was in his happiest and most inspiring vein, and Washington was equally happy in his address. Among the auditors were many of England's most eminent men, including the Honorable James Bryce. As a result of the occasion, invitations poured in on Washington to address different institutions, to have responded to even a fraction of which would have prostrated him anew. He spoke several times, but was forced to limit his acceptance of invitations.

Mr. Choate gave the distinguished American a reception where he met for the first time the eminent humorist, Mark Twain. The greatest function attended was that of a tea given by Queen Victoria at Windsor Castle, where Washington met many other eminent Americans. In the House of Commons he conversed with Sir Henry Stanley, and was prepared thereby to advise his people in America that the United States, with all its disadvantages to the race, was vastly preferable to migration to Africa. With Mrs. Washington he became guest in the mansions of lords 


\section{LIFE OF BOOKER T. WASHINGTON}

and ladies, dukes and duchesses, and wealthy Englishmen in their manors. The chief cities were visited, and the rural regions, as well. In England Washington found the highest aspect of real life he had ever witnessed. He was not so captivated by the sheen and glitter of mansion and castle as by the country life of the English. The precise adjustment of affairs the most trifling, scientifically and patiently arranged so that everything had a place and one knew where to find it when wanted, the time which the English took to do everything solidly and well, without haste or bustle, clatter or confusion, greatly pleased him. He was delighted with the hazy landscapes, the care of the soil to prevent its washing, the fields rolled and combed till they appeared to be finished with a pencil instead of a plow, the undulating stretches of grassy meadows, green and luxuriant, over which browsed the herds of sleek cattle, and sheep with their heavy coats of wool, the banks of streams lined with solid masonry, so the waters could not wear away the fields, the care of domestic animals in order to the return of superior dividends in service, and the arrangement of the homes of England, built with respect to comfort rather than of architectural beautythese thoughts were absorbed to be taken with all their suggestiveness of value back to Tuskegee.

While Washington would not agree with Alfieri that Italy and England are the only countries worth living in, he was delighted with the rigid English methods of life. Plastic and receptive as his mind was, always on the outlook for suggestions of the things 
that help, there came instinctively the association of all that was now passing under review with that which was taking place in the little, distant, evolutionary center at Tuskegee. While not indifferent to the kindness and courtesy extended by the nobility of England, for these were not without meaning to him as a representative of his race, yet that which he could practically accumulate and assimilate for the good of his people was of immensely more value than receptions, dinners, and public addresses. $\mathrm{He}$ was not a man to be dazzled by the bedizened trappings and splendors of the court to the obliviousness of the severely practical, and as the time came for him to turn again homeward he took with him the value of varied observation enjoyed, to turn it to gain when he reached the scene of his labor.

Thus went by restfully, agreeably, profitably, the respite of three months in distant lands. Without the least regret or reluctance he now turned toward America and his own cherished Tuskegee. As a vessel laden with rich argosies from a distant port, he was bearing back to his ordinary work the golden seeds of travel to be sown into the minds and characters of a youthful generation of a yet comparatively obscure race of people, but one the power and progress of which had already come to claim the attention of the world.

The return trip was distinguished by one incident that is worthy of mention. As Professor Washington sat reading the "Life of Frederick Douglass," and just as he had finished reading an account of the 


\section{0}

\section{LIFE OF BOOKER T. WASHINGTON}

mistreatment accorded him on a certain occasion when Douglas was returning home from Europe, a party of ladies and gentlemen, a self-constituted committee, came in a body into the library, and requested that he would consent to deliver that evening an address to the assembled passengers. He gladly accepted the invitation, and made the address, a number of Southerners being present, and all greeted his remarks with repeated expressions of applause. Governor Benjamin B. Odell, of New York, presided at the meeting, and after the delivery of the address a handsome sum was raised for the school at Tuskegee. Without respect to section the party gathered about Professor Washington after the speech, and offered their congratulations. He saw in this the great change wrought in public sentiment within the span of a few years. If the passengers on a steamer in former years had meted out mistreatment to Douglass, a miscellaneous party of both Northerners and Southerners now showed the most marked distinction to Washington. 'As he construed it, the difference lay not between the two men, but between the times. The incident gave fresh elasticity to his spirit of hopefulness as he viewed the future. 


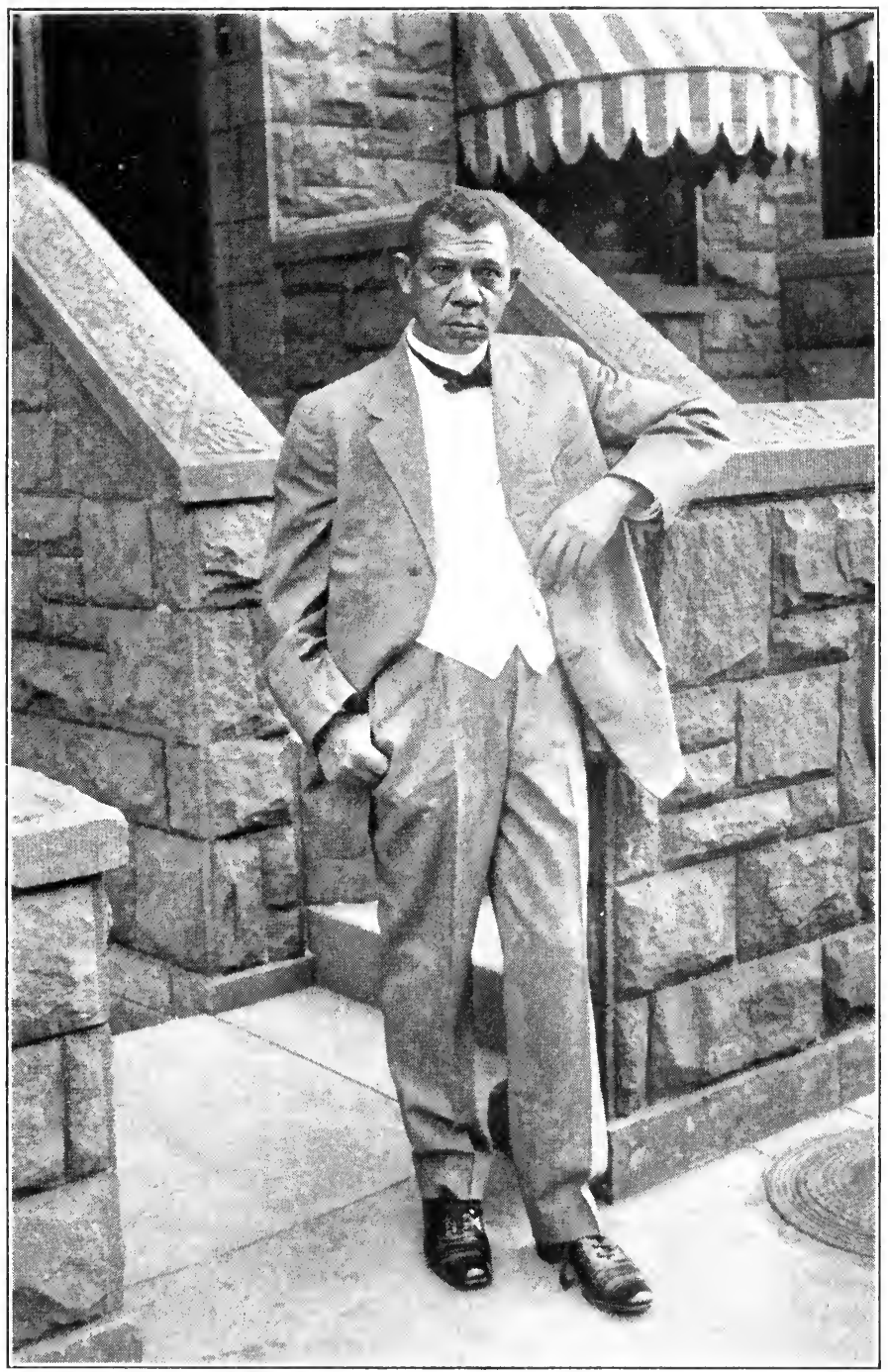

BOOKER T. WASIIINGTON

Taken During a Late Visit to Jew Jirk 



\section{XXI}

\section{LAST YEARS}

W

$\mathrm{E}$ have now come to the last period of the career of this remarkable man. In the preceding chapters the events of his life have been followed with sufficient explicitness of detail to obviate the necessity of recalling anything relating to his life from the cabin of the slave to the position of distinction which he came to hold in the nation and in the world, for his reputation had become international. He occupied as high a niche as was possible for a Negro in the American states. His ability was universally recognized and he was honored for his integrity and wisdom. The name of no American was more familiar to the popular ear than was his. As before shown he was an incessant laborer, his toil keeping pace with the expansion of his work for his cherished school at Tuskegee, in particular, and for the colored race in general. His steps had now become long strides, and much that he had in former years done, was now largely done through others. Not that this released his personal touch and profound daily concern, but these were now exercised in a different and in a more efficacious way. The amount of labor rendered by him was prodigious. But slight allusion has been made to his distinctive
\[ 281 \] 


\section{LIFE OF BOOKER T. WASHINGTON}

literary work, which was within itself immense, and yet this was done at snatches of time when he had to make fresh drafts on his strength after having dispatched his other work. His literary productions were eagerly sought and read by both races. His principal works are, "The Future of the-Negro," "Up Erom-Slavery" (an autobiography), "The Story of the Negra" (in two volumes), "Working with the Hands," "Character Building," "The Negro in Business,." "My Larger Education," and "The Man Farthest - Down." Besides, he wrote many essays, booklets, and articles for the leading magazines. Neither in speech nor with pen did he attempt the ornate, but his diction is as clear as amber, and is fascinating in its simplicity.

His closing years became so general in the service rendered that the story of his career during this last period will have to be equally so. More than any other he had become the oracle of his race. His piquant proverbs were quoted by all alike, and they abide as a part of the current and proverbial thought of the South. On all questions relative to the relations between the races, he was consulted as authority.

This recalls the timely service rendered by him in connection with the Atlanta riots which took place in September of 1906. Rumors of insults and assaults on white women had reached the city and it was greatly stirred; in consequence, violence broke out indiscriminately against the Negro population, to quell which the state troops were ordered out. A race war seemed inevitable. The better and wiser ele- 
ments of both races came together, and it was deemed best to summon Dr. Washington to Atlanta to assist in the restoration of order. $\mathrm{He}$ was never in better position to serve both races, and was one of the chief contributors to the restoration of order at that crisis. His service was patriotic and timely in behalf of both races.

Demand was frequently made on his time for addresses before leading institutions of learning, clubs, and different organizations. If he had accepted a tithe of them, there would have been left to him but a slight margin of time. His office at Tuskegee was besieged by callers who visited the school as one of the attractions of a trip through that part of the South, and having seen the fine buildings on the large grounds of the Institute, and the model farms and ranches adjacent, naturally wished to meet the famous founder.

Not far from Tuskegee was Auburn, the location of the Alabama Polytechnic Institute, between which school and the Tuskegee Normal and Industrial Institute were the most cordial relations; it became a custom to have a mutual exchange of visits between a select deputation of students during each session. The influence of Washington on his race throughout the nation, and especially throughout the South in which nine-tenths of his people are, had become potential. He kept in vital touch with every enterprise begun and fostered by his race, from end to end of the country. Under his direction local schools had sprung up in districts where they were most needed 


\section{LIFE OF BOOKER T. WASHINGTON}

by reason of the density of Negro population, industries of varied sorts were established, large districts of land were purchased on easy terms, banks were founded, state and local fairs were held, agricultural and commercial clubs were organized, newspapers and magazines were published, and his people were moving with no uncertain strides toward the fulfillment of his original conception.

One of the happiest conceptions was that of the publication at Tuskegee at the beginning of each year, of a handsome volume known as the Negro-Year Book, an annual encyclopedia of Negro progress. It is ably edited by Professor Monroe N. Work, and is a compendium of most valuable information relating to every phase of the history of the race and of its achievements. This annual encyclopedia is destined to become one of the most valuable means of reference concerning the history and work of the Negro.

Be it said to the credit of Dr. Washington, that he was nowhere so popular as at Tuskegee where he was best known, and where he had resided an honorable citizen for more than thirty years. The neat homes of his people line the highways of the county, and their well-tilled farms are everywhere seen. Though in the Black Belt in which is massed an immense population of Negroes, there has not been committed in the county a crime of any degree of seriousness since his residence at Tuskegee. In the early nineties, he organized at Tuskegee a conference of his people which annually meets in increasing numbers, till the attendance has come to exceed a thousand of repre- 
sentative men and women of the race. These bring important reports from every part of the broad field of the South, relative to every phase of Negro lifethe progress, the industries, the successes, the failures, the advantages and difficulties, the prospects and the peculiar drawbacks-all are gone over, suggestions are made, experiences are compared, and general good results.

At another season comes another assemblage, the Tuskegee Negro Farmers' Conference, to which are brought tangible evidences of the products of field, garden, and stock farm, all of which are displayed in friendly rivalry and with astonishing results. On these occasions addresses are numerous from orators of both races, and both become beneficiaries of the great displays made and, in consequence, of the speeches. The orderly arrangement of products and of stock, and the entertainment afforded the visitors are wonderful, and exhibit the master mind that conceived and executed. The contribution thus made to race comity of sentiment and good-will is incalculable.

Tuskegee long ago became the Mecca of the colored race, especially of the South, and Booker T. Washington throughout his life was the transcendent leader. By their loyalty to him he was enabled to open, year by year, fresh avenues of advancement, and by a reaction most natural, he was enabled to render increasing service to his people. Each recurring year called forth a fresh stock of energy and of force from him as he continued to blaze the way through the thicket of difficulty, to be eagerly followed by his people. 


\section{LIFE OF BOOKER T. WASHINGTON}

Never with the slightest truculence of spirit, but often in sadness, would he crave the responsiveness needed on the part of the white race. Much encouragement he received, and in many instances, the utmost that could be accorded, but with clearness of vision he saw that with a spirit of general responsiveness on the part of the dominant race, the situation could be cleared of its difficulties. While a marvelous change had come to the South, and while multitudes had come to see the advantage derived by society in general, yet there was a large segment of the white race who in the indulgence of aversion withheld the encouragement which he so seriously implored. While there was much to encourage, there was much that discouraged. His power and force were constantly thrown in the direction of the encouragement of his people, the progress of whom produced favor to society in general, while, on the other hand, the power and influence of many of the dominant race were employed in taking advantage of a weaker people. One of his temperament and cast of thought could see how very easy it would be to exercise greater kindness, and he could not understand how the element of white unfriendliness could be content to engage force rather than suasion and patience, simply because force could be exercised. He chafed yet the more because there were no means by which he could give expression to his sentiments, as he knew that he would be misunderstood did he go beyond a certain limit of suggestiveness, protest, and appeal. There was nothing left but to endure. $\mathrm{He}$ had in- 
dulged the hope that as the race should gradually emerge from its condition of lowliness there would be corresponding responsiveness of appreciation, and while this was not wanting on the part of multitudes of white friends, it was not commensurate the one with the other. He observed that while there were numerous white friends whose sympathy was with him in his efforts, yet they abstained from expression of this out of regard for the unpopularity which it might incur, and therefore the sympathy entertained did not extend beyond a silent shake of the head or a shrug of the shoulders.

If from the side of the whites the situation was considered and discussed as a race problem, from his point of view there were difficulties in the opposite direction. How it was possible, for instance, for officers of the law, in the exercise of their official functions, officers from the lowest local functionary to the highest in the state, acting under the sanctions of solemn oaths to administer the laws equally, to pass over with icy indifference so many outrages of violence against his weak and defenseless people, was to him often amazing. He invariably counseled peace and patience on the part of his race, the results of which were social benefits, yet the abuses continued. To his practical and philosophical mind schooled in the furnace of adversity, he could see how it would cost the unfriendly and violent element of the white race nothing to accord consideration, but when, instead of this, there were violence and hostility, optimistic as 


\section{LIFE OF BOOKER T. WASHINGTON,}

he naturally was, he could not see how this phase of the situation could be changed.

Over barrier after barrier the Negro race had come with little to stimulate and much to discourage, yet this wanton lawlessness of arbitrary force continued, while the high sources of authority betook themselves to silence and apparent indifference. He voiced again and again to his people the absolute necessity of being law-abiding, honorable, prompt, upright, and always respectful. Yet violent and chaotic destruction of order by members of the white race would often pass for naught by officials, while the slips and trips of his people were exaggerated. Not only was this true, but not infrequently bands of irresponsible men under the cover of darkness wreaked vengeance on the innocent merely on suspicion, and without taking care to investigate the basis of their suspicion. In this way innocent victims were made to expiate crimes, the discovery of their innocence being sometimes made after they had been killed.

The examples of atrocities like these bewildered him. Yet he must remain silent. Meanwhile, with now and then an exception, those in authority, either through sympathy of sentiment, or out of respect for a sentiment which they dare not disregard, would raise not a finger and lisp not a syllable in arrest of a wanton procedure like this. What could be done to stay these bloody, nightly forays? He asked not that the criminal Negro be spared the full application of the law, but if society was to be domineered by these nocturnal visitants, terrorizing with pistol, rope, and 
fagot, whose life was safe? Under conditions like these where were the safeguards of society? What bulwarks of protection could, under these conditions, fence about civilization? How could a man of peace and progress encourage his people amidst circumstances which meant only demoralization without ceasing? The fact that the black man was left without appeal under these conditions, gave to him the bit terness of sadness. The utmost left him was to publish in the leading journals of the South, each year, the list of lynchings that had taken place, and the causes assigned, with the dim hope that the conscience of the public would at some time be smitten, and an arrest be made to the grewsome butchery.

For the kind protection accorded him, he was most grateful. He had gone, never armed, often into the far interior. He was well known as the leader of the race, and not the slightest affront at the South had ever been his. But men and women of his race as innocent as he, had been many times seized under cover of darkness and beaten or killed for causes of which they knew nothing. These things he could not understand, and they wrung his soul in silent agony. He would turn his thoughts from a ghastly spectacle like this and not alone himself seek to keep directly in the path of right, but would continue to admonish his people thus to do, cherishing the hope that a new conscience would one day come, and with it a cessation of these tangled troubles. But here again his hopes were dashed, as the infection spread northward along the 


\section{LIFE OF BOOKER T. WASHINGTON}

color line, north of the Ohio and beyond the Potomac, and even into the new West.

In the summer of I9IO, the trustees of the Tuskegee Institute, noting the inroad made on Dr. Washington's health by his incessant labor, granted him a leave of absence for needed rest, and he went again to Europe. He traveled over much of the continent, on a trip of practical observation, with the special purpose of studying the conditions of the under classes in the different nations from the point of view of an American Negro. He went leisurely and observantly, studying the conditions of the toiling masses in each European state visited, the nature of the labor of each class, their homes, food, compensation, sanitary conditions, and the general opportunities afforded in life. As a result of this extensive tour he embodied his observations in a lucid volume of great sociological merit, with the conclusion that, hard as the lot of the American Negro often is, it is vastly superior to that of the laboring masses of Europe.

At that time Dr. Washington was in the full maturity of his powers. His observations among the laboring classes of America, and especially among the people of his own race were excelled by those of none, and no one was better able to pronounce judgment than he. Incidents of every phase of the life of the people who toil in Europe are presented in the volume, "The Man Farthest Down," in a most graphic way, and his work proved to be one of the most valuable contributions to sociological literature. In addition to this, it became-a valuable sidelight to the European 
struggle which broke forth so suddenly in August, I9I4.

His mission being accomplished, both with respect to recuperation and to the object of his tour, Dr. Washington returned to his work at Tuskegee. The increasing claims on his time and vitality as the school continued to expand, began after some months again to tell on his health. He was duly warned by his friends, but with his usual lightness of spirit, he did not share in the expressed apprehension, and labored as never before. Demands on his time continued, and it became evident that he was yielding to the incessant strain of labor and of years. All efforts made to persuade him to relax were unavailing, and while he had most competent and efficient co-laborers like Professor Emmet Scott, and Treasurer Logan, besides a host of others, and while, in large measure, the general management of the institution had passed into their hands, he was not content unless he was in vital touch with every possible interest. His presence was as much demanded in New York as at Tuskegee, because of the extensive interests of the school, and, like a pendulum, he swung between the two points.

$\mathrm{He}$ was not an old man and, under ordinary conditions, should have been in his prime. He was approaching his fifty-ninth birthday, and to appearances he seemed to be vigorous, but his strength was fast ebbing out. To him the struggle became one of seeking to persuade himself that he was in as full possession of manly vigor as ever, but his vitality was rapidly oozing away. 


\section{LIFE OF BOOKER T. WASHINGTON}

As the last summer of his life came on, he was obliged to have more frequent recourse to cessations of labor, but he no sooner experienced a change for the better than he again plunged into work as he had done during all his straining life. He had become so indispensable to his people that they came to consider him a kind of oracle, and to have him present on an occasion was an inspiration. Demands on his time and energy continued to the last and, with a loyalty rarely equaled, he would respond to the extent of his ability. In the exuberance of his enthusiasm in the constant strides now made by his people, he forgot himself, and continued to tax his strength to the utmost tension. It was impossible for him to comply with all the demands made on him, but he prosecuted his labors where he felt that the most could be accomplished. This he did to the end, and when he fell it was with the harness still on. His profound interest eclipsed all things respecting himself and his physical condition, and he could not be persuaded to believe that the end was near. His plans were still projected far into the future when he was smitten down, and from sheer exhaustion could go no farther. He was a race patriot to the core, and died a martyr to the interests of the colored people of America.

In September, 1915, Dr. Washington delivered an address before the colored National Baptist Convention, of which he was a member, in the Armory at Chicago, and later spent a week on the shores of Mobile Bay, the guest of Mr. Clarence W. Allen. With the spirit of a boy he enjoyed fishing in the warm 
waters and inlets of the bay, and at the end of the week expressed himself as feeling unusually well; but doubtless this expression was more due to the desire for a return to perfect health than to a fancied realization. The spirit was stronger than the flesh.

October 23, he left Tuskegee to attend the annual meeting of the American Missionary Association at New, Haven, in connection with the National Conference of the Congregational churches. On the evening of October 25, he delivered his last address before the combined assemblage in Woolsey Hall, Yale University. Thence he went to New York.

The renewal of activity after his brief respite on Mobile Bay served to develop afresh a nervous trouble to which he had become a victim, and so seriously was it telling on him, that on reaching New York, Messrs. Seth Low, William G. Willcox, and Frank Trumbull, all of whom are distinguished members of the board of trustees of the Tuskegee Institute, prevailed on him to go to St. Luke's Hospital, in that city, for thorough examination and treatment. The services of an eminent specialist, Dr. W. A. Bastedo, were promptly procured and after a thorough examination he announced that Dr. Washington was "completely worn out, and in addition was suffering from nervous exhaustion and from arterio-sc!erosi-.."

It was evident that the end was near, and Mrs. Washington was promptly summoned by wire. When the sufferer learned that he soon must die, he asked to be taken back to his native South, that he might die at the scene of his long labor and of his triumph. 


\section{LIFE OF BOOKER T. WASHINGTON}

Every comfort was provided for the long trip South, and, a totally helpless man, Booker T. Washington was taken to Tuskegee to die.

Throughout the trip he was unconscious till he reached Chehaw, the station a few miles from Tuskegee, where the local short line deflects from the main road. Then came a slightly lucid interval, when he was told that he was soon to reach Tuskegee. Only once again did he revive, and that was to learn that he was at last in his own home. $\mathrm{He}$ reached there after night on Saturday, and was destined never again to open his eyes on the light of this world, for a few minutes before five o'clock on Sunday morning, November I4, I915, his spirit fled.

He had rounded out his life as he wished. His race had been relieved of many of the dire encumbrances from which it was suffering twenty-three years before, when as a young man he had set himself to the task of race redemption. He had not only succeeded in subduing much racial rancor, but he had built an institution the fame of which had gone over the world. As a fountain this school had sent out innumerable rills of force and of fruitfulness, all of which he was now able to bequeath to his still struggling people, but struggling now with vast advantage gained, rather than without hope and encouragement.

A mur with a record so monumental could afford thus silcntly to die. It was befitting that it was so. For more than three decades his voice had been heard from ocean to ocean, his active and prolific brain had never ceased its exercise, his magnetic influence for 
peace and good-will had been most potent, and his tongue, hands, and pen had never known idleness. When Booker Taliaferro Washington died-the one for many-America lost one of its greatest spirits. He sank

"...... as sinks the morning star,

Which goes not down behind the darkened west, Nor hides obscured amid the tempests of the sky, But melts away in the light of heaven."

When the news of the death of Booker T. Washington was flashed over the country, expressions of regret and of sympathy came from every quarter of the country and from every class, and notably from the white newspapers of the South.

But the touching scenes witnessed as the great Negro lay in state for several days, were in connection with his own people. The following incident is typical of many others, and expresses the tribute most dear to his own heart:

"Most pathetic of all was the sight of the humble and unlettered colored people of the cotton fields who literally packed the school grounds. They had sustained a loss which they did not know how to voice. You could see them looking into every face near them for encouragement to say how much they were hurt and how they would miss their devoted friend.

"Unless the visitors had been with Dr. Washington through a quarter of a century and observed how much he loved these simple poor of his race, how anxiously he worked to help them, they could not understand how broken-hearted these older colored people were. In the past, when they have come to Tuskegee, Dr. Washington has treated them as if they were princes. They were 


\section{LIFE OF BOOKER T. WASHINGTON}

thinking of this when they gazed for the last time upon his silent form.

"One old couple, themselves near the sunset of life, walked a long, long distance to be here. Piteously the man approached one of the instructors and with trembling lips and eyes that overflowed asked: 'Do you reckon they will let us see Booker?' and he hurried to explain: 'We have come so fur jes' to see him de las' time. Do you reckon they will mind us looking at him?' They were especially escorted to the casket and given their heart's desire ; for Dr. Washington's love for them when he was here cannot be described." 


\section{INDEX}

Abolitionis m, a revival of, 32 Adams, Lewis, a valuable exslave, II2

Age - Herald (Birmingham, Ala.) alluded to, 229

Alabama, disquietude in, I09; legislature of, appropriates $\$ 2,000$ to Negro education, I IO; "grandfather clause" in its constitution, I44

Alfieri quoted, 278

American Baptist Missionary Society aids the Negro, 256

American Missionary Association aids the Negro, 256; meeting at New Haven the occasion of Washington's last address, 293

Antwerp visited, 273

Armstrong, Gen. Samuel C., his venture at Hampton, 60 ; dis cover s Washington's qualities, 62; accompanies him North, I8I

Atlanta Exposition, 87; effects of Washington's address on occasion of, 214

Attucks, Crispus, alluded to, 228

Bastedo, Dr. W. A., Washington's last physician, 293

Bedford, Rev. R. C., 218

Bell, Alexander Graham, alluded to, 218

Boyd, Dr. R. H., 25 ; capitalist, 244

Brickmaking at Tuskegee, 158 Bryce, Hon. James, alluded to, 277

Bruce, Senator B. K., 25; in the senate, 96 ; qualities of statesmanship, 244

Buchanan, James, President, alluded to, 30

Bullock, Gov. of Georgia, 202

Campbell, G. W., an early friend of the Negro, III

Campbell, W. W., a Southern friend to the Negro, 26I

Capitalists become interested in Tuskegee, 24I

Carey, William, alluded to, 85

Carnegie, Andrew, alluded to, 258 ; his letter to Washington, 259

Charlotte, N. C., honors Washington, 253

Chautauqua, 218

Chesnutt, Charles W., the Negro novelist, 244

Chicago, Washington's notable speech at, 228

Choate, Joseph, Ambassador, greets Washington in London, 277

Civil War, its immediate results, 33

Cleveland's (President) letter to Washington, 209

Cromwell, Oliver, alluded to, 236

Curry, Dr. J. L. M., alluded to, 224; general agent of the Slater Fund, 200

Davidson, Miss Olivia A., Washington's valuable assistant, I26; her character illustrated, I27; her zeal, I56 Demoralization, Southern, I54 
Development, principle of, 22 Discrimination, unjust, I43, 245

Disfranchisement, 238

Dober, Moravian missionary to the West India slaves, 85

Douglas, Frederick, alluded to, 279

$\mathrm{Du}$ Bois, Prof. W. E. B., quoted, 176; Negro scholar, 244

Dunbar, Paul Laurence, Negro poet, 244

El Caney, battle of, 228

Eliot, President of Harvard, writes to Washington, 218

England, Washington's impression of, 278

Europe, Washington's first trip to, 270 ; second, 290

FARMers' Conference at Tuskegee, 285

Fortune, T. T., Negro editor, 244

France, attention shown Washington in, 274

Galloway, Bishop, relation to the Negro, 233

Garrison's (F. J.) special interest in Washington, 27I

Gilman's (President D. C.) invitation to Washington, 210

Gilreath, Belton, a friend to the Negro, 26I

Grooves, J. G., the "potato king," 244

Haiti, alluded to, 19

Hampton Institute, its spirit, 63

Harrison's (ex-President) attention to Washington, 274

Harvard University confers degree on Washington, 219

Haygood, Bishop A. G., defends the Negro, 233
Holland, visited, 273

Houston, Texas, speech at, 234

Howell's (Hon. Clark) comment on Washington's Atlanta speech, 206

Hudson, Port, battle of, alluded to, 228

IMMIGRATION, foreign, discussed in the South, 152

Industry, Washington's idea of, 265

Ireland, Archbishop, meets Washington in Paris, 274

JACKson, Gen., alluded to, 228 Jasper, Rev. John, noted colored preacher, 25

Jefferson's (Thomas) forecast of emancipation, 17

Jews of England, a parallel, 236

Kentucky, State University of, begun, 45

$\mathrm{Ku}$ Klux Klan, 83; serious barrier to Washington, 97

LAMAR's (Hon. L. Q. C.) estimate of Senator Bruce, 96 Leadership, indispensable, I5 Lee, Gen. Robert E., alluded to, 208

Lessing, quoted, 88

Lewis, Hon. W. H., - Negro jurist, 244

Liberia, alluded to, 19

List of Washington's books, 282

Lodge, Hon. Cabot, alluded to, 219

London visited by Washington, 276

Long, Hon. J. D., alluded to, 220

Lord, Nathalie, her service to Washington, $7 \mathrm{I}$ 
Low, Hon. Seth, chairman of the Board of Trustees, Tuskegee, 260; kindness to Washington in his last illness, 293

Luxembourg Palace, visit to, 275

Lynching, 145

MAckIE's (Miss) aid to Washington, 74

McKinley, President, invited to Tuskegee, 223; his address at Tuskegee, 225

Malden, W. Va., 40; Negro school at, 42; Washington's return to, 72

Marshall's (Gen.) kindness to Washington, I30

Mason, Dr. M. C. B., noted orator, 244

Miles, Gen. Nelson A., alluded to, 218

Miller, Prof. Kelley, a noted scholar, 244

Mobile Bay, 292

Moravians, the first missionaries to the Negro, 84

Morris, Dr. E. C., noted Negro leader, 244

National Baptist Convention, address to, 292

Negro, original condition of, I5; in Cuba, I9; prosperity of, 19 ; condition after freedom, 20 ; outlook, $2 \mathrm{I}$; sudden transition, 23; disposition of, 24; first venture on citizenship, 36 ; misconception of freedom, 38; demoralizing influences, 39 ; first schools of, 44; incorrect idea of, 68; motherly devotion of, 73 ; original estimate of an educated, 77 ; handicaps, 79; creating the idea of a home, 86; devotion of, 87 ; disadvantages of, 87 ; " prob- lem," 91 ; rough experiences of, 92 ; as Washington found his condition in Alabama, II6; early struggles of, at Tuskegee, II8; remarkable

loyalty of, I33; his sphere as viewed by Washington, 266

Negro Business League organized, 25I ; in different states, 251

Nitzschmann, Moravian missionary to the Negro, 85

OberLin College, 227

Odell, Gov. Benjamin B., alluded to, 280

Pettiford, Dr. W. R., 25; a capitalist, 244

Pillow Fort, 228

Polytechnic Institute, of Alabama, kind relations with Tuskegee, 283

Porter, A. H., I50

Porter, Gen. Horace, Ambassador to France, 274

Porter's (J. A.) letter to Washington, 226

Press comments on Washington's degree from Harvard, 221

Property acquired by Negroes, 252

ReAding, Lord, of England, 236

Reconstruction, 35

Religion and the Negro, 45

Rockefeller, John D., Sr., alluded to, 258

Roosevelt, President, false report concerning, I68; member of the Tuskegee Board, 200

Rosenwald, Julius, alluded to, 258

Rotterdam, 274 
Ruffner, Gen., 5I ; exactness of Mrs., 52

\section{San Domingo, I9}

Santiago, battle of, 228

Savage, Dr. M. J., 218

Scott, Prof. Emmet, Washington's colaborer, 29I

Scott, Dred, case, 30

Shafter, Gen., 225

Slater (John F.) Fund aids Tuskegee, 260

Slavery a school of civilization, 18

Smith, Postmaster-General, 226

South, The, after the war, 34 ; unfavorable publications to the Negro in the, 82

Spanish-American War, 228

Stanley, Sir Henry, greets Washington in London, $27 \mathrm{I}$ Stephens, Alexander, quoted, 3 I

TAFT, President W. H., 260

Taney, Chief Justice, 30

Tanner, Bishop, race' leader, 244

Tanner, $H$. O., the famous painter, 244; his work in Paris, 275

Terrell, Judge Robert H., colored jurist, 244

"The Man Farthest Down," 290

Trotter, J. M., noted editor and leader, 244

Trumbull's (Frank) kindness, 293

Turner, Bishop H. M., 244

Tuskegee, original, 106; Institute begins under improved conditions, I35; handicaps, 136; progress of, 157; crude conditions, I63; sufferings, I70; attains prominence, I86; President McKinley's visit to, 225; an unbiased opinion of, 249
Twain, Mark, alluded to, 7; meets Washington in London, 277

VICTORIA, Queen, invites Washington to tea, 277

Vincent, Bishop J. H., 218

WALKer, Dr. C. T., 25

Washington, Booker $T$., his prominence, 7 ; popularity, 9; position in American history, II ; compared with others, 28; birth, 29; his mother, 30 ; first ambition, 35 ; first venture into the world, 40 ; first steps in knowledge, $4 \mathrm{I}$; struggles to gain an education, 46; anecdote, 47 ; assumes a name, 48; hears of Hampton, 49; kindness of his brother, 50; goes to Hampton, 53; rough experiences, $54 ;$ character shown, 55; attracts attention, 59; engages as waiter, 68; his estimate of Hampton, -7I ; rapid development, 75 ; distinguished graduation, 76 ; seeks employment if the East, 79; opens à school at Malden, 80; controlled by Hampton ideal, $8 \mathrm{I}$; progress at Malden, 89; encounters sore trials, 94 ; goes to Wayland Seminary, 95; impressions gained of Washington City, 96; called to canvass West Virginia, 97; honored, 99; called to Hampton, I00; placed in charge of Indians, IOI ; called to Tuskegee, II3; disappointment, II4; his vision, 128; buys land, I30; his example, I3I ; policy of, I39; unjust estimate of, 146 ; goes North, I6I ; character established, I66; at the White House, I68; treatment 
accorded him, I72; sanity of, I73; a boon to both races, I75; impression made on the North, I82; speech before a congressional $\mathrm{co} \mathrm{m} \mathrm{mit} \mathrm{t} \mathrm{e} \mathrm{e,}$ I92; Atlanta speech, 193; his literary works, 246 ; misconceptions of, 262 ; his wives,
27I ; death, 294; pathetic scene, 295

Wheeler, Gen. Joseph, alluded to, 225

Willcox's (William G.) marked kindne'ss, 293

Work, Prof. M. N., and his compendium, 284

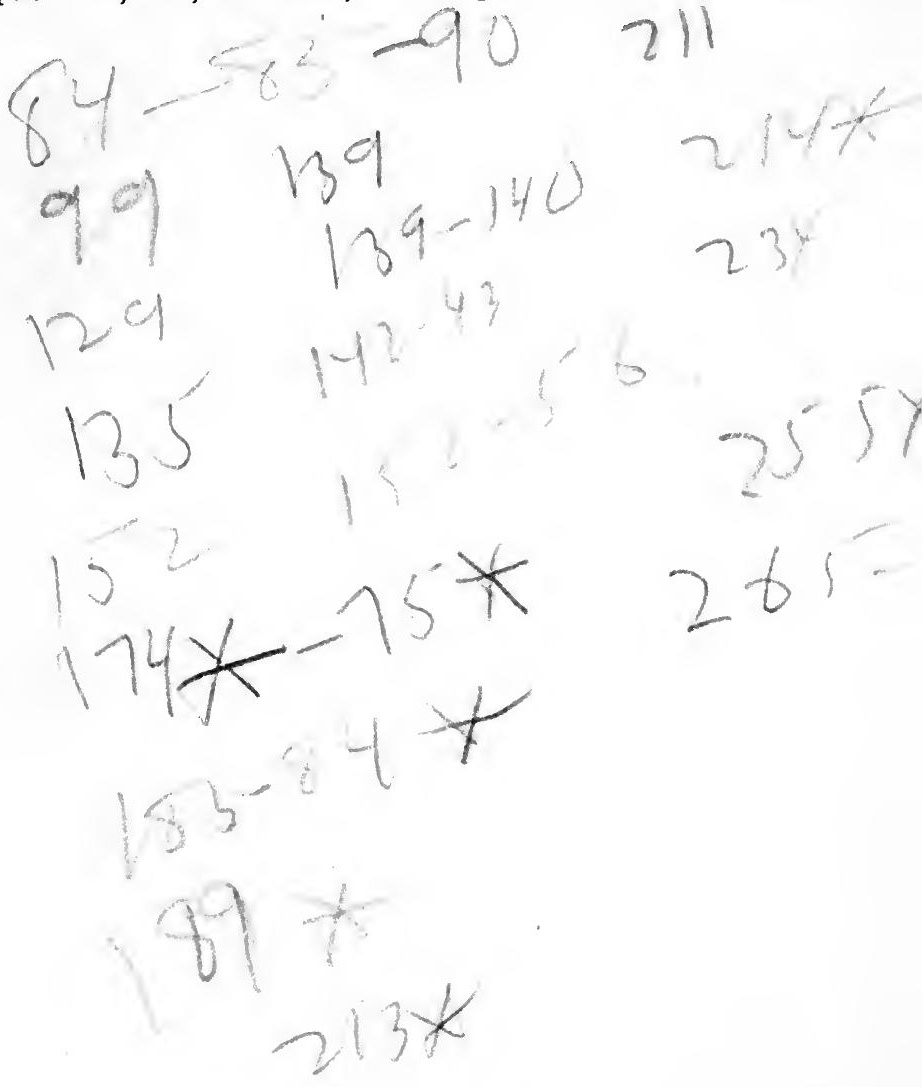

PRINTED IN THE UNITED STATES OF AMERICA 


RETURN TO the circulation desk of any University of California Library or to the NORTHERN REGIONAL LIBRARY FACILITY Bldg. 400, Richmond Field Station University of California Richmond, CA 94804-4698

LL BOOKS MAY BE RECALLED AFTER 7 DAYS month loans may be renewed by calling (415) 642-6753 year loans may be recharged by bringing books to NRLF

enewals and recharges may be made 4 days prior to due date

DUE AS STAMPED BELOW

\section{H 81990}




\section{YC 27990}

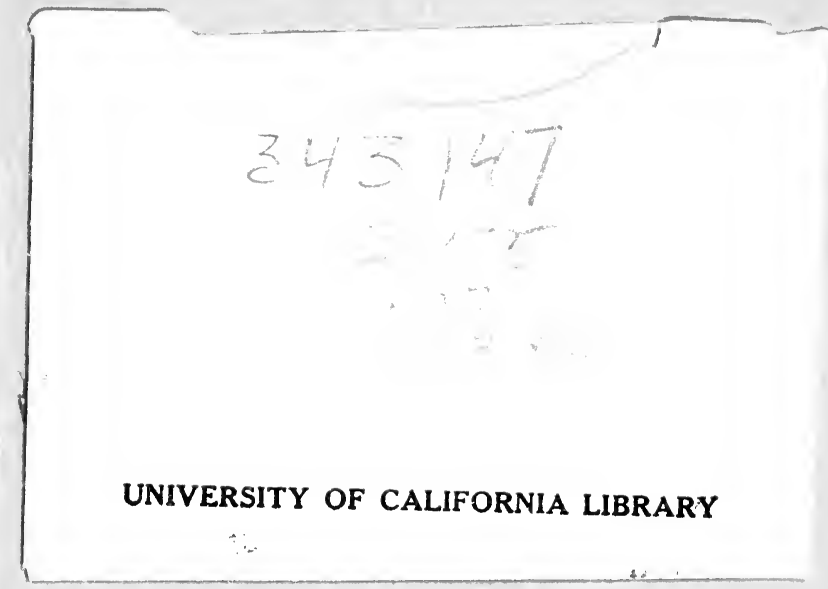

$$
\cdots 9 \vdots
$$




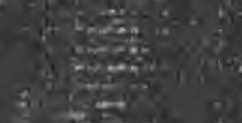

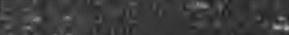

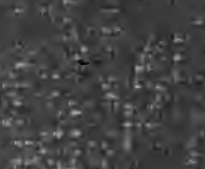
20.12:

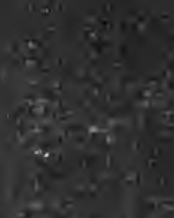

